九州大学学術情報リポジトリ

Kyushu University Institutional Repository

The Influence of Light And Temperature On Certain Characters of The Silkworm, Bombyx Mori

Kogure, Makita

Tokyo University of Agriculture and Technology

https://doi.org/10.5109/22568

出版情報：九州大学大学院農学研究院紀要. 4 (1)，pp.1-93，1933-09. Kyushu Imperial University バージョン：

権利関係 : 


\title{
THE INFLUENCE OF LIGHT AND TEMPERATURE ON CERTAIN CHARACTERS OF THE SILKWORM, BOMBYX MORI
}

\author{
Makita KoGURE
}

\section{CONTENTS}

INTRODUCTION

PART I. INFLLENCE ON HIBERNATION AND EGG COLOR

HISTORICAL REVIEW

MATERIALS AND METIYODS

EXPERIMENTAL, RESULTS

I. Production of Dark- and Light-colored Eggs

1. Stages to be influenced by light and temperature
A. Incubation period
B. Larval period
C. Pupal period

2. Relation between light and temperature in producing moths laying dark colored eggs

A. Eifects of light intensity at different temperatures

B. Effects of different wave-lengths of light at different temperatures

C. Effects of the length of day at different temperatures

3. Effects of environmental conditions upon the production of mixed batches

A. Effects of light and temperature during the incubation period

B. F.ffects of light and temperature during the pupal period

C. Different features of the initial and final deposits in mixed batches with reference to temperature during the pupal period

4. Color grades of dark- and light-colored eggs

A. Effects of temperature upon the color variation of dark-colored eggs

B. Effects of temperature upon the color variation of light-colored eggs

II. Hibernation of Dark- and Light-colored Eggs

1. Production of non-hibernating eggs out of the dark-colored

A. Effects of light and temperature during incubation 
B. Eifects of temperature during the pupal period

C. Effects of temperature after the time of egg laying

2. Production of hibernating eggs out of the light-colored -

A. Effects of temperature during the pupal period

B. Fffects of temperature after the time of egg laying

III. General Consideration on Hibernation and Egg Color in the Silkworm Eggs

1. Problem of hibernation

2. On the first hibernation substance

3. On the second hibernation substance

4. Interrelation between the grades of egg color and hibernation of eggs

5. Characteristics of the three types of voltinism

SUMMARY OF PART I

PART II. INFLUENCE ON THE NLMBER OF MOLTS

HISTORICAL REVIEW

MATERIAILS AND METHODS

EXPERIMENTAL RESULTS

1. Occurrence of the three-molter as influenced by light and temperature during the incubation period

A. Effects of light

B. Fffects of temperature

C. Concurrent and antagonistic action of ight and temperature during the incubation period

2. Occurrence of the three-molter as influenced by light and temperature during the larval period

A. Effects of light

B Effects of temperature

C. Concurrent and antagonistic action of light and temperature dur. ing the larval period

3. Sex-ratio of the three-molters

4. Racial difference of rates of the appearance of the three-molter

ON THE CAISE OF THE MOLTING

SUMMARY OF PART II

BIBLIOGRAPIIY

For Part I

For Part II

\section{INTRODUCTION}

Studies of the effects of light and temperature on organisms have becn receiving considerable attention for over a century, but after the discovery of various instruments by which light and tem- 
perature can be regulated they have made very rapid progress. Among the literature, some relations of metabolism or growth of organisms light and temperature have been announced, but very little knowledge on the qualitative change of a certain character as influenced by the two agents.

This paper follows the influence of light and temperature upon certain characters of the silkworm, Bombyx mori, such as egg color, hibernation and larval molts. The different stages in the life-cycle of the silkworm differently respond to light and temperature, with results that the eggs of the same batch are colored either dark or light, and those either hibernating or unhibernating, and the larvae molt either three or four times. Further, new hypotheses on hibernation of the silkworm eggs and on the molting of larvae is discussed in this connection.

This work was carried on at the Nagano-ken Sericultural Expsriment Station. I wish to express my thanks for the laboratory facilities provided by Mr. Z. Mizur, Director of the Nagano-ken Sericultural Experiment Station. I am most deeply indebted to Prof. Y. TANAKA for his stimulating guidance throughout the course of the work and for looking through the manuscript. Thanks are also due to Dr. H. ITo, Professor of the Imperial Tokyo Sericultural College, for encouragcment and constructive criticism concerning Part II, and to Dr. K. Watanabe, expert of the Imperial Sericultural Experiment Station, for valuable advices given by him regarding the investigation of Part I.

\section{PART I \\ INFLUENCE ON HIBERNATION AND EGG COLOR \\ Historical Review}

Although the problem of voltinism of insects has been discussed by many authors, the results obtained by them are considerably divergent. Some more important literature may be cited below.

Tower ('06) made an interesting observation on hibernation of certain beetles. When they were kept in a cage where temperature was high and moisture low, they hibernated through a year and a half, but emerged whenever the moisture content of the soil in- 
creased. The phenomenon of dormancy of the same species was also studied by BAUMBERger ('17) and BreitenBECHER ('18). The latter showed that desiccation caused the beetles to pass into a state of induced dormancy. Shelford ('27) attributed the cause of hibernation of this species to some action of enzymes. The problem of voltinism with the corn borer discussed by CRAWFORD ('22) and BARBER ('25). BABCOCK ('27) found that moisture was the most important factor in this connection and concluded that there is a progressive adaptation, or acclimatization, to new conditions when the animal invades inew areas. HAMLIN ("23) rcported that the pyralid moth brought about the development of three annual generations instead of two, as usual, under adaptive conditions. The problem of hibernation of house and stable flies was quoted by ROUBAND ('22) in connection with that of voltinism. The same problem was dwelt on by PICARD ('27). ROUBAND explained the dormancy in the various insects worked with as due to an auto-intoxication caused by the uric excretion in the adipose tissue. RoBinson ('2S) brought the physiological aspects of the problem of hibernation to light by means of surgical treatment of insects. He pointed out that a change of the water content of the tissues following injury induced a modification of the colloidal state of the protoplasm. Recently Dawson ('31) discovered the phenomenon, in the polyphemus moth, that the physiological state resulting in pupal dormancy could rapidly be induced during the last larval stage by lowering temperature.

In all of the studies so far enumerated, temperature and humidity were shown to the efficient agents to modify the type of voltinism, and little has been known of the effects of other environmental conditions in inducing hibernation.

In regard to the problem of voltinism of the silkworm, there exists a great amount of literature. Some of them may be worthy of note. Toyama ('06) observed the phenomenon of maternal inheritance by means of crossing univoltine and bivoltine races; later McCracken ('09), Castle ('10), Toyama ('13), De ('15), Cleghorn ('18), Uda ('23), Tanaka ('24), Watanabe ('24) and UMEYA ('26) took part in the same genetical research. WATANABE proved that both the univoltine and bivoltine were dominant over the tetravoltine, and that of all environmental conditions by which hibernation could be induced, temperature was so effective that in 
bivoltine and tetravoltine races hibernation resulted without exception when the eggs of preceding generation were kept at a high temperature of $25^{\circ} \mathrm{C}$. Further he ascertained that only when the eggs were incubated in a low temperature, e.g., $20^{\circ} \mathrm{C}$., temperature during either the larval or pupal life influences the percentage of hibernating cggs in the next generation. The sericulturist, however, knows by experience that even when subjected to a high temperature of $25^{\circ} \mathrm{C}$. during the incubation period, eggs of bivoltine and tetravoltine races do not necessarily give hibernating eggs only.

Moisture and nutrition have been said also to be influential on voltinism by Harada ('21), Mizuno ('25) and UMeYa ('28). According to them, a dry condition during egg incubation and inanition or feeding the larvae of mulberry leaves of the inferior quality give rise to less numbers of hibernating eggs than when the eggs werc incubated under a moist condition, and fed with an ample amount of good leaves. This conclusion has, however, not yet been established.

Very little knowledge has been published on the variation of egg color. WatANABE ('21) found, in the silkworm, the fact that pigment granules in the serosa spread or assemble according to temperature. In this case, the quantity of pigment does not appear to be changed.

Since 1927, I have been studying the effects of light upon hibernation and egg color, and have ascertained that light modifies the type of voltinism, accompanying the alteration of egg color. I have, therefore, pursued the effects of light in combination with temperature on voltinism and egg color in different races during the larval, pupal as well as embryonic periods of the silkworm.

WATANABE set forth a hypothesis that hibernation depends upon the amount of an "inhibitory substance" in the cytoplasm of the egg cell or body fluid. By means of ovarian transplantation and blood transfusion between different races, UMEYA also came to conclude that the deposition of a "voltinism-determiner," particular enzyme in the body fluid, predisposes to hibcrnation. These two investigators' explanations seem to me not more than a postulation of the same substance, no matter what designation may be used.

There are two kinds of silkworm eggs, the "dark-colored" and the "light-colored." The batch of eggs laid by a single moth is 
usually uniform in color. It has been admitted that all dark - colored eggs, which produce dark violet pigment within the serosa several days after laying are hibernating and light-colored eggs having little or no pigment in the serosa do not hibernatc. I have, however, discovered that dark-colored eggs are not necessarily hibernating, and a proportion of light-colored eggs may, in certain circumstances, be capable of hibernation. From this fact, I would postulate two substances concerning hibernation in the silkworm eggs, the one determines hibernation in addition to the coloring of the serosa, while the other determines hibernation, having a little connection with the small variation of egg color.

\section{Materials and Methods}

Three groups of races, univoltine, bivoltine and tetravoltine, were used in my experiments. Among them, bivoltine races, in particular, were used in the experiments which related to the effect of light only, because they are not only so vigorous that they could be reared without failure from spring till fall, but that they are, as ascertained experimentally by WATANABE, very susceptible to environmental conditions so far as their voltinic character is concerned. Among bivoltine races I preferred two races, Showa, a Chinese, and Shohaku, a Japanese bivoltine, which were both bred and named at the Nagano-ken Sericultural Experiment Station.

With the aim of pursuing the effects of light and temperature in combination, Japanese races such as bivoltine Shohaku, tetravoltine Tsunomata and univoltine Japanese No.1, were used. In a few cases Okusa and Nisshin, Japanese bivoltine races, and European No. 9, univoltine race, were used.

Eggs of bivoltine and tetravoltine races were refrigerated at $2.5^{\circ} \mathrm{C}$. from winter till the beginning of incubation, and the univoltine eggs at $0^{\circ} \mathrm{C}$. In most cases, I used dark-colored eggs hatched out artificially by immersing them in hot dilute hydrochrolic acid, a method now commonly practised by silkworm-egg raisers. Hibernated eggs and artificially hatched ones gave practically the samo results so far as my experiments are concerned. The eggs of each batch were divided into a number of approximately equal parts in order to avoid the dissimilarity of batches. Counts of the moths laying dark-colored or light-colored eggs were made after 
fifteen days or so when the coloring of the serosa had become obvious. Countings of hibernating eggs out of the light-colored and those of non-hibernating eggs out of the dark-colored, were done in eggs preserved under natural conditions till the winter.

Of many cnvironmental factors more attention was paid to light and temperature. The light source used was Mazda lamps of 20 or 40 watt. The intensity was measured at times by a Macbeth illuminometer or by a foot-candle meter approximately, and kept at $0.5 \mathrm{~F}$. C. or so during the experiments. Lest the intensity may vary, the voltage and current were kept as constant as possible, by means of a regulator devised by myself, and the bulbs were changed frequently. To prevent ascending of temperature, the bulb was immersed in cold water, or was screened by a heat-absorbing glass plate $4.5 \mathrm{~mm}$. thick. The light incubation was made in boxes, the top of which covered by a transparent glass plate. The dark incubation was done in boxes of the same size, the upper glass of which was shaded by charcoal paper. For the light rearing, a tray, $1.0 \mathrm{~m}$. long, $0.7 \mathrm{~m}$. wide and $0.2 \mathrm{~m}$. deep, the top of which was made by a transparent glass plate, was used. In the dark rearing, a glass plate of a tray was covered with charcoal paper. On two sides of the tray, there were two small holes for ventilation. In cases of the dark rcaring, feeding etc. was operated several times a day in the dark room under a red lamp. The results obtained by this way showed no difference with the cases where all operations were carried out in a dark room. Pupae were cared for in boxes of $0.7 \mathrm{~m}$. in length, $0.5 \mathrm{~m}$. in width, and $0.7 \mathrm{~m}$. in height, the four sides and top of which were made of transparent glass plates. To make dark, the glass plates were painted black.

The temperature was controlled by means of special incubators, ordinary rearing rooms, or rooms with regulated environmental conditions such as temperature, moisture, light, ventilation and so forth after Carrier's system. The temperature read on the record. ing instruments did not vary more than $0.5^{\circ} \mathrm{C}$. from the desired temperature in any case.

It was rather difficult to keep an even moisture through the dry spring and the wet summer. Humidity was, however, kept between 70 and 85 per cent in the incubator or the rearing room. Within the limits, moisture seems to have little effect on voltinism and egg color. In the Carrier's rooms the humidity of 75 per cent 
was exactly maintained during the experiments. Of course care was taken, to feed larvae with approximately equal amount of mulberry leaves of the same quality for the same experimental lots.

\section{Experimental Results}

\section{Production of Dark- and Light-colored Eggs}

1. Stages to be influenced by Light and Temperature

Although WATANABE took the dark-colored for hibernating eggs, and the light-colored for non-hibernating ones, he showed that every batch of eggs laid by moths of bivoltine and tetravoltine races was completely clark-colored by the application of a high temperature of $25^{\circ} \mathrm{C}$. during the incubation period, while they became light-colored under temperatures lower than $15^{\circ} \mathrm{C}$., and that the coloring of eggs was also influenced by a low $\left(20^{\circ} \mathrm{C}\right.$.) or a high $\left(30^{\circ} \mathrm{C}\right.$.) temperature during the larval and pupal periods, when eggs were incubated at an intermediate temperature of $20^{\circ} \mathrm{C}$.

Failure was sometimes met with on this procedure, no matter how satisfactorily moisture might be controlled during the incubation period. This was possible due to the effect of light which was put out of consideration in his experiments. I intended to work out the problem how and when light only as well as light and temperature combined affect the coloring of eggs in the lifecycle of the silkworm.

\section{A. Incubation Period}

At first, in purpose to examine the effect of light only during the incubation period, eggs of fifteen batches of Showa race were taken out from the refrigerator and each of these batches was divided into eleven lots. They were immediately put into a dark incubator of a constant temperature of $19^{\circ} \mathrm{C}$. On the second day the first lot was brought to the light, and thereafter one lot after another was brought to the light at $8 \mathrm{a} . \mathrm{m}$. every other day or every day. The last was drawn out on the sixteenth day, when most of the eggs had hatched out. Whenever each was drawn out, a number of eggs were fixed and preserved for observation of embryos. The results obtained from the eleven lots are shown in Table 1. 


\section{Table 1}

Results of the experiment in which each lot was removed from the dark to the light

\begin{tabular}{|c|c|c|c|c|}
\hline \multirow{2}{*}{$\begin{array}{c}\text { Date on } \\
\text { which lots } \\
\text { were } \\
\text { brought to } \\
\text { the light }\end{array}$} & \multicolumn{2}{|c|}{ Number of moths } & \multirow{2}{*}{$\begin{array}{c}\text { Percent. of } \\
\text { moths laying } \\
\text { dark-colored } \\
\text { eggs }\end{array}$} & \multirow{2}{*}{$\begin{array}{l}\text { State of development of the } \\
\text { embryo at the time when it } \\
\text { was brought to the light }\end{array}$} \\
\hline & $\begin{array}{c}\text { dark-colored } \\
\quad \text { eggs } \\
\end{array}$ & $\begin{array}{c}\text { light-colored } \\
\text { eggs }\end{array}$ & & \\
\hline 2nd & 45 & 1 & 97.83 & Thoracic legs appeared. \\
\hline 4 th & 71 & 1 & 98.61 & The embryo began to con- \\
\hline eth & 59 & 4 & 93.65 & $\begin{array}{l}\text { The blastokinesis of the em- } \\
\text { bryo setting in. }\end{array}$ \\
\hline 8 th & 78 & 3 & 96.30 & $\begin{array}{l}\text { The embryo in the course of } \\
\text { blastokinesis. }\end{array}$ \\
\hline 10 th & 65 & 1 & 98.48 & The blastokinesis completed. \\
\hline 11th & 45 & 8 & 84.91 & $\begin{array}{l}\text { The tracheae differentiated, } \\
\text { the mouth parts began to } \\
\text { be colored. }\end{array}$ \\
\hline 12th & 52 & 13 & 80.00 & $\begin{array}{l}\text { The head colored, setae ap. } \\
\text { peared. }\end{array}$ \\
\hline 13th & 51 & 28 & 64.56 & $\begin{array}{l}\text { The embryo nearly full deve. } \\
\text { loped, integument colored. }\end{array}$ \\
\hline 14 th & 32 & 33 & 49.23 & $\begin{array}{l}\text { The coloring denser, ocelli } \\
\text { visible. }\end{array}$ \\
\hline 15 th & $€ 5$ & 47 & 58.04 & $\begin{array}{l}\text { About one-half of eggs hat- } \\
\text { ched out. }\end{array}$ \\
\hline 16 th & 61 & 40 & 60.40 & Most of eggs hatched out. \\
\hline
\end{tabular}

As is seen above, the lots brought to the light in the earlier days, or before the blastokinesis of the embryo, produced higher percentages of moths laying dark-colored eggs.

An experiment was carried out, after the reverse manner, i.e., a set of nine lots brought to the light on the fourth day of incubation were put into the dark at $8 \mathrm{a} . \mathrm{m}$. every day, one by one. The temperature was kept at $25^{\circ} \mathrm{C}$. up to the fourth day of incubation, and thereafter it was kept at $19^{\circ} \mathrm{C}$.

Table 2 shows that the more moths laying dark-colored eggs were produced, the later the eggs were removed from the light into the dark.

From above tables we learn that the effect of light upon egg color could be recognized at any time after the completion of blastokinesis of the embryo which takes place at about seventh day of incubation, as ascertained by WATANABE for temperature. 


\section{Table 2}

Results of the experiment in which each lot was removed from the light to the dark

\begin{tabular}{|c|c|c|c|c|}
\hline $\begin{array}{l}\text { Date on } \\
\text { which lots }\end{array}$ & Number & of moths & Percent. of & State of development of the \\
\hline $\begin{array}{l}\text { were put } \\
\text { into the } \\
\text { dark }\end{array}$ & $\begin{array}{c}\text { dark-colured } \\
\text { eggs }\end{array}$ & $\begin{array}{c}\text { light-colored } \\
\text { eggs }\end{array}$ & $\begin{array}{l}\text { moths laying } \\
\text { dark-colored } \\
\text { eggs }\end{array}$ & $\begin{array}{l}\text { embryo at the time when it } \\
\text { was put into the dark }\end{array}$ \\
\hline 4th & 35 & 66 & 34.65 & The embryo in the course of \\
\hline 5 th & 47 & 47 & 50.00 & $\begin{array}{l}\text { The blastokinesis finished } \\
\text { completelv. }\end{array}$ \\
\hline Eth & 37 & 72 & 33.9 .1 & The mouth parts colored. \\
\hline 7th & 49 & 27 & 64.47 & The tracheae differentiated. \\
\hline 8 th & 89 & 8 & 91.75 & The head colored. \\
\hline 9 th & 76 & 3 & 96.20 & The integument colored. \\
\hline 10 th & 87 & 0 & 100.00 & The embryo advanced to the \\
\hline 11 th & 69 & 3 & 95.83 & Most of eggs hatched out. \\
\hline 12 th & 84 & 1 & 98.82 & All the eggs hatched out. \\
\hline
\end{tabular}

The next experiments were made in order to find the period of embryonic development to be affected by light at different temperatures. Twenty hibernated egg batches of the race Showa were divided into two groups. Each group was again divided into nine lots. When the embryo reached the stage of the blastokinesis, they were put in darkness, being brought to the light one after another every day and exposed to light for three days in one group, and five days in the other group, and then they were put in darkness again until the end of the embryonic life. Seven lots out of nine in each group were treated as above, the remaining two being the controls, i.e., continuous light and continuous darkness. Temperature was kept at $20^{\circ} \mathrm{C}$. constantly during the incubation period.

At $20^{\circ}$, five days were enough to let moths lay dark-colored cggs, whilst three days were somewhat insufficient thereof The fact that the most effective stage was found between the sixth and tenth days, when tracheae, blood and other organs are differentiated, may have, as will be discussed later, a significance from the physiological standpoint. 
Table 3

Effects of the duration of light to which the embryo was cxposed at a temperature of $20^{\circ} \mathrm{C}$.

\begin{tabular}{|c|c|c|c|c|}
\hline \multirow{2}{*}{$\begin{array}{l}\text { Date on which lots } \\
\text { were brought to } \\
\text { the light }\end{array}$} & \multirow{2}{*}{$\begin{array}{l}\text { Number of } \\
\text { days in the } \\
\text { light }\end{array}$} & \multicolumn{2}{|c|}{ Number of moths } & \multirow{2}{*}{$\begin{array}{l}\text { Percent. of } \\
\text { moths laying } \\
\text { dark-colored } \\
\text { eggs }\end{array}$} \\
\hline & & $\begin{array}{l}\text { datk-colored } \\
\text { eggs }\end{array}$ & $\begin{array}{l}\text { light-colored } \\
\text { eggs }\end{array}$ & \\
\hline 5 th & 3 & 94 & 4 & 95.92 \\
\hline 6 th & 3 & 82 & 8 & 91.11 \\
\hline 7th & 3 & 74 & ij & 92.50 \\
\hline 8th & 3 & 99 & 4 & 96.12 \\
\hline 9 th & 3 & 102 & 7 & 93.58 \\
\hline $10 \mathrm{th}$ & 3 & 87 & 5 & 94.57 \\
\hline 11 th & 3 & 97 & 10 & $99 . \ell 5$ \\
\hline continuous light & 14 & 79 & 0 & 100.00 \\
\hline continuous darkness & 0 & 54 & 34 & 61.36 \\
\hline$\quad \ldots \ldots$. & $\cdots$ & - & $\ldots \ldots$ & -- \\
\hline 5 th & 5 & 120 & 1 & 99.17 \\
\hline Eth & 5 & 151 & 0 & 100.00 \\
\hline ith & 5 & 162 & 0 & 100.00 \\
\hline 8 th & 5 & 136 & 0 & 100.00 \\
\hline 9 th & 5 & 127 & 4 & 95.95 \\
\hline 10th & 4 & 149 & 2 & 98.68 \\
\hline 11 th & 3 & 102 & 21 & 82.93 \\
\hline continuous light & 1.1 & 114 & 0 & 100.00 \\
\hline continuous darliness & 0 & 67 & 60 & 52.76 \\
\hline
\end{tabular}

Another experiment was performed with twelve batches of Shohaku at a low temperature of $15^{\circ} \mathrm{C}$. The treatment was carried out reversely to the foregoing experiment. The results follows :- 
Table 4

Effects of the varying number of days in which the embryo was kept in the dark at a temperature of $15^{\circ} \mathrm{C}$.

\begin{tabular}{|c|c|c|c|c|}
\hline \multirow{2}{*}{$\begin{array}{c}\text { Date on which lots } \\
\text { were put into the } \\
\text { dark }\end{array}$} & \multirow{2}{*}{$\begin{array}{l}\text { Number of } \\
\text { days in tne } \\
\text { dark }\end{array}$} & \multicolumn{2}{|c|}{ Number of moths } & \multirow{2}{*}{$\begin{array}{l}\text { Percent. of } \\
\text { moths laying } \\
\text { dark-colored } \\
\text { eggs }\end{array}$} \\
\hline & & $\begin{array}{l}\text { dark-colored } \\
\text { eggs }\end{array}$ & $\begin{array}{c}\text { light-colored } \\
\text { eggs }\end{array}$ & \\
\hline 7 th & 10 & 23 & 42 & 35.38 \\
\hline 10 th & 10 & 10 & 51 & 16.39 \\
\hline 13 th & 10 & 12 & 59 & 16.90 \\
\hline 16 th & 9 & 27 & 39 & 40.91 \\
\hline continuous light & 0 & 61 & 34 & 64.21 \\
\hline continuous darkness & 26 & 0 & 54 & 0 \\
\hline 7 th & 15 & 10 & 79 & 11.24 \\
\hline 10 th & 15 & 1 & 80 & 1.23 \\
\hline 13 th & 13 & 2 & 93 & 2.04 \\
\hline 16 th & 9 & 21 & 68 & 23.EO \\
\hline continuous light & 0 & 71 & 40 & 63.96 \\
\hline continuous darkness & 26 & 0 & 92 & 0 \\
\hline
\end{tabular}

As shown in Table 4, less numbers of moths laying darkcolored eggs were recognized in the lots which were put into darkness on the tenth and thirteenth days. The lots placed for ten days in the dark gave more moths laying dark-colored eggs as compared with continuous darkness, but those of fifteen days succeeded in producing as many moths laying light-colored eggs.

In 1928, eggs of Shohaku and Tsunomata were divided into eight parts which were put into constant temperatures at $28^{\circ}, 24^{\circ}$, $20^{\circ}$ and $15^{\circ} \mathrm{C}$., respectively, at which one of the two parts was kept in continuous light, the other in continuous darkness. In the next year, eggs of Shohaku and Showa were divided into six parts, every two of which were kept at $25^{\circ}, 20^{\circ}$, and $15^{\circ} \mathrm{C}$. Four parts of eggs of Japanese No. 1 were taken, two being kept at $20^{\circ}$, two at $15^{\circ} \mathrm{C}$, and at a given temperature one part of the two was kept 
in the light, the other in the dark. The results are shown in Table 5.

Table 5

Effects of light and temperature combined during the incubation period upon the production of moths laying dark-colored eggs

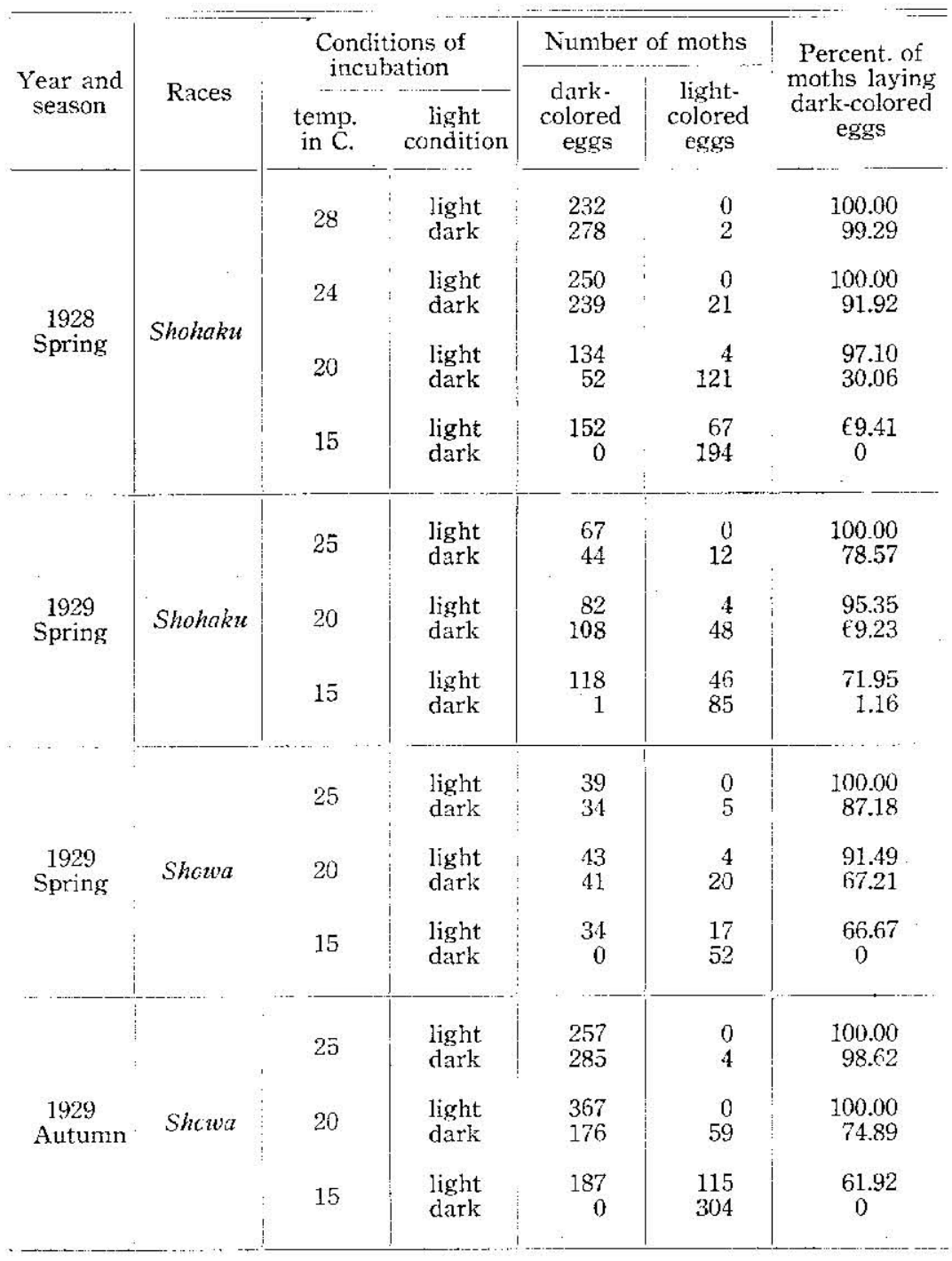




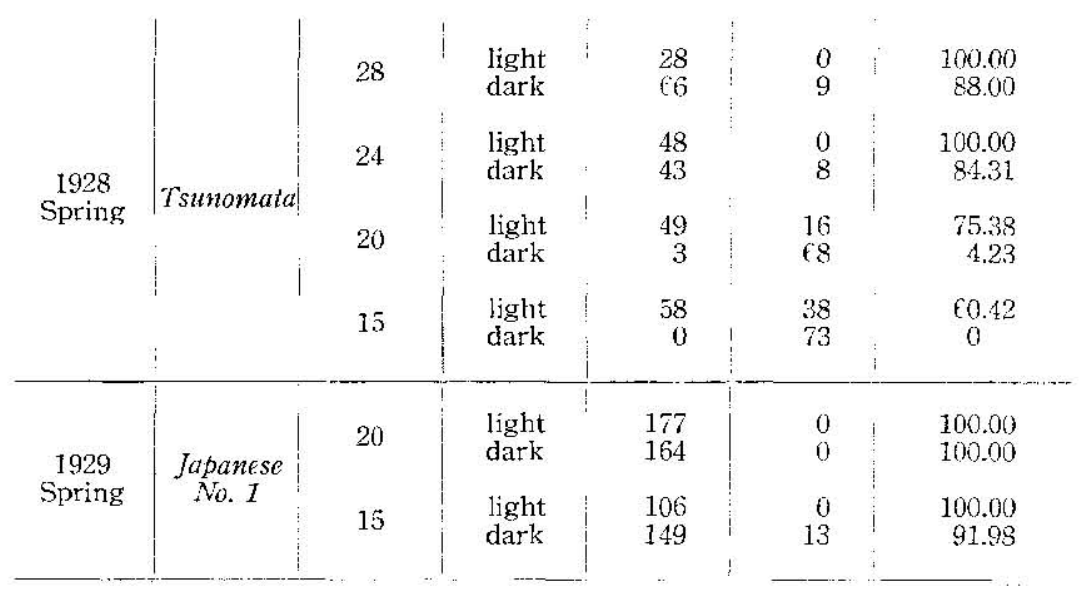

The table shows divergent results in the races of different voltinism. In the bivoltine races, Shohaku and Showa all turned into moths laying light-colored eggs at the temperature of $15^{\circ}$ in the dark. At $24^{\circ}$ and $25^{\circ}$ in the light, and at $28^{\circ}$ either in the dark or in the light, total moths laid dark-colored eggs. The temperature of $20^{\circ}$ in the light and that of $24^{\circ}$ in the dark resulted in moths laying dark-colored eggs over 90 per cent. Intermediate percentages were obtained at $15^{\circ}$ in the light, and at $20^{\circ}$ in the dark.

In the tetravoltine race, Tsunomata nearly the same percentages of moths laying dark-colored eggs as in the bivoltine were obtained, except that intermediate percentages resulted at $24^{\circ}$ in the dark, and at $20^{\circ}$ in the light.

Now we come to the univoltine race Japanese No. 1 . Here, the temperature of $15^{\circ}$ in the dark gave a small percentage of moths laying light-colored eggs and not a single moth under other conditions.

Shohaku produced higher percentages of moths laying darkcolored eggs than Showa. A considerable variability was observed in Showa reared in the different seasons, spring and autumn, as well as in Shohaku reared in different years, 1928 and 1929, in the case of incubation at the temperature of $20^{\circ}$ in the dark and at that of $15^{\circ}$ in the light.

\section{B. Larval Period}

In the experiments so far described, where the eggs were in- 
cubated at an intermediate temperature in the dark, and a low temperature in the light, somewhat variable results were obtained. This seems to suggest the possibility that some effects of light and temperature are present some time in or after the larval period. As to temperature, WATANABE verified the fact that high temperature during the earlier larval stadia and low temperature during the later larval stadia were conducive to the production of darkcolored eggs and vice versa. But very little attention was paid to the independent effect of light and still less to combined action of light and temperature. The results of my experiments on this point are stated in the following pages.

a) Eatier larval stadia (first, second and third instars). An experiment was performed to investigate the independent effect of light. The eggs of seven batches of Showa incubated at $19^{\circ} \mathrm{C}$. in darkness were brought into the room temperature $\left(24^{\circ} \mathrm{C}\right.$.) and parcelled out into five lots ; 1) light for the first instars, dark for the second and third; 2) light for the second instars, dark for first and third; 3) light for the third instars, dark for the first and second; 4) light throughout the three earlier stadia ; 5) dark throughout the same period.

\section{Table 6}

Results of the experiment to determine the effect of light during the earlier stadia

\begin{tabular}{l|c|c|c}
\hline $\begin{array}{c}\text { Light conditions and } \\
\text { stadia }\end{array}$ & $\begin{array}{c}\text { Number of moths } \\
\text { dark-colored } \\
\text { eggs }\end{array}$ & $\begin{array}{c}\text { Percent. of } \\
\text { light-colored } \\
\text { eggs } \\
\text { moths laying } \\
\text { dark-colored } \\
\text { eggs }\end{array}$ \\
\hline $\begin{array}{c}\text { stadium 1 light } \\
\text { stadium 2 light }\end{array}$ & 60 & 92 & 41.40 \\
stadium 3 light & 26 & 97 & 38.22 \\
stadia $1+2+3$ light & 79 & 98 & 20.97 \\
stadia $1+2+3$ dark & 3 & 98 & 44.63 \\
\hline
\end{tabular}

The results in Table 6 indicate that light had a great effect during the first and second stadia, but a considerably smaller effect during the third stadium, and that much more moths laying dark- 
colored eggs were produced, when the larvae were kept light throughout the earlier period than they were kept in darkness.

To know any relation which might exist between the effects of light and temperature in the earlier larval stadia and those in the incubation period, the eggs of forty batches of Shohaku were parcelled out into eight parts, and every two were put into constant temperature incubators at $28^{\circ}, 24^{\circ}, 20^{\circ}$ and $15^{\circ} \mathrm{C}$. Twenty batches of Tsunomata were treated in a similar way, and fifteen batches of Japanese No. I were parcelled out into four parts, every two of which were put at $20^{\circ}$ and $15^{\circ} \mathrm{C}$., respectively. At each of the temperatures in these experiments, one part was kept in the light, the other in the dark. Larvae from each of the eight parts of eggs, in case of Shohaku, were divided into four approximately equal groups, two of which were reared at $28^{\circ}$ and two at $20^{\circ} \mathrm{C}$. throughout the earlier stadia, lasting from hatching up to the beginning of the third stadium. For each temperature again one of the groups of larvae was fed in the light and one in the dark. In ease of Tsunomata and Japanese No. 1, larvae from each of the experimental parts were divided into two groups, one kept light and at the high temperature during the young stages, and the other under opposite conditions. The later stadia and pupae of the treated lots were kept at the room temperature of $24^{\circ} \mathrm{C}$.

Table 7

Effects of light and temperature combined during the incuabtion and the earlier larval stadia upon the production of moths laying dark-colored eggs

\begin{tabular}{|c|c|c|c|c|c|c|c|}
\hline \multirow[b]{2}{*}{ Races } & \multicolumn{2}{|c|}{$\begin{array}{l}\text { Conditions of } \\
\text { incubation }\end{array}$} & \multicolumn{2}{|c|}{$\begin{array}{l}\text { Conditions of rearing } \\
\text { the earlier instars }\end{array}$} & \multicolumn{2}{|c|}{ Number of moths } & \multirow{2}{*}{$\begin{array}{l}\text { Percent. of } \\
\text { moths lay- } \\
\text { ing dark- } \\
\text { colored eggs }\end{array}$} \\
\hline & temp. in & $\begin{array}{c}\text { light } \\
\text { conditions }\end{array}$ & temp. in & \begin{tabular}{|c|} 
light \\
conditions
\end{tabular} & $\begin{array}{l}\text { dark- } \\
\text { colored } \\
\text { eggs }\end{array}$ & $\begin{array}{l}\text { light- } \\
\text { colored } \\
\text { eggs }\end{array}$ & \\
\hline & & & 28 & $\begin{array}{l}\text { light } \\
\text { dark }\end{array}$ & $\begin{array}{l}209 \\
133\end{array}$ & $\begin{array}{l}0 \\
0\end{array}$ & $\begin{array}{l}100.00 \\
100.00\end{array}$ \\
\hline & & light & 20 & $\begin{array}{l}\text { light } \\
\text { dark }\end{array}$ & $\begin{array}{l}186 \\
138\end{array}$ & $\begin{array}{l}0 \\
0\end{array}$ & $\begin{array}{l}100.00 \\
100.00\end{array}$ \\
\hline & 28 & & 28 & $\begin{array}{l}\text { light } \\
\text { dark }\end{array}$ & $\begin{array}{l}293 \\
224\end{array}$ & $\begin{array}{l}0 \\
2\end{array}$ & $\begin{array}{r}100.00 \\
99.12\end{array}$ \\
\hline $\begin{array}{l}\text { Sho- } \\
\text { hakut }\end{array}$ & & dark & 20 & $\begin{array}{l}\text { light } \\
\text { dark }\end{array}$ & $\begin{array}{l}206 \\
144\end{array}$ & $\begin{array}{l}0 \\
0\end{array}$ & $\begin{array}{l}100.00 \\
100.00\end{array}$ \\
\hline
\end{tabular}


Light and Temperature on Characters of Silkworm

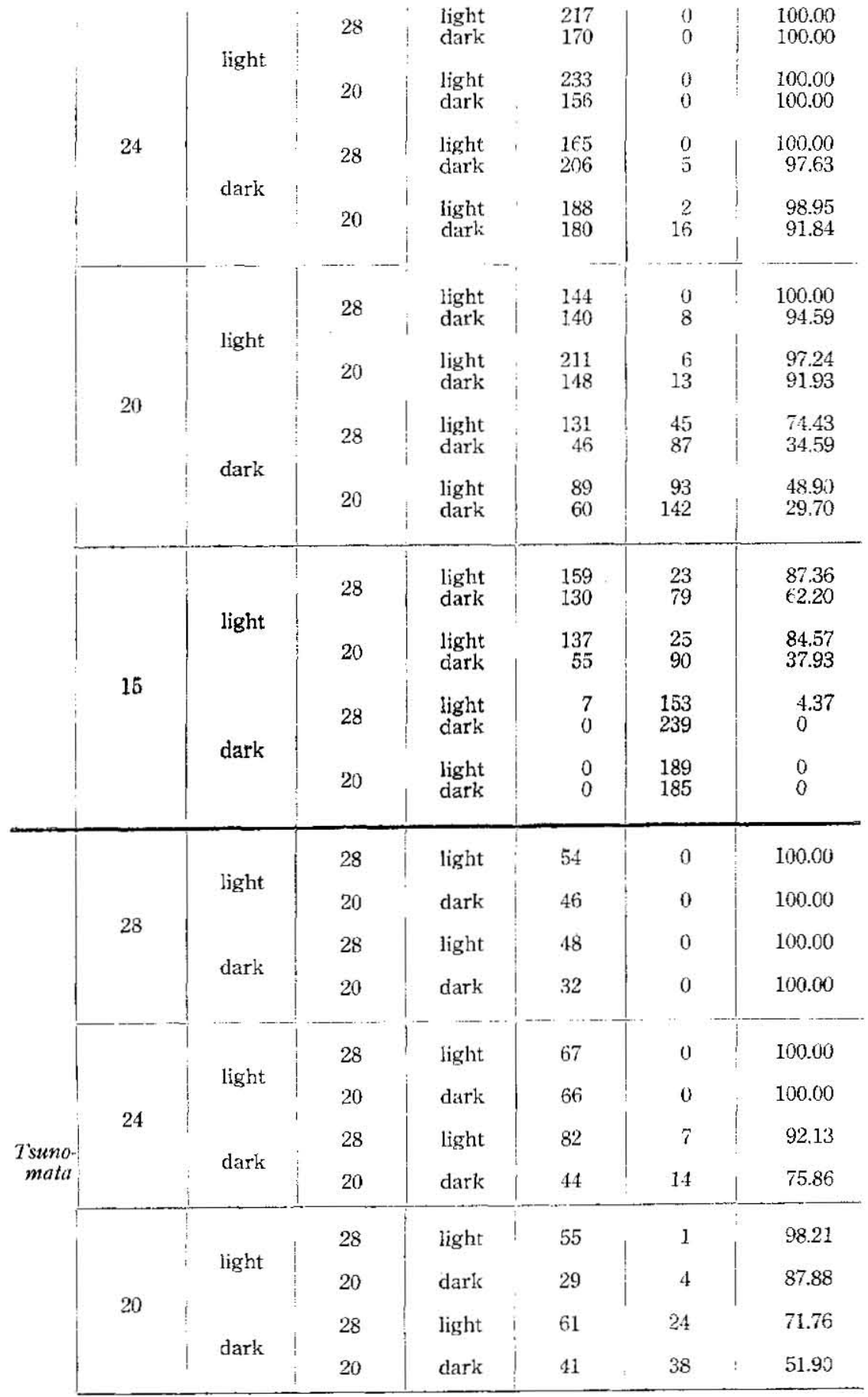




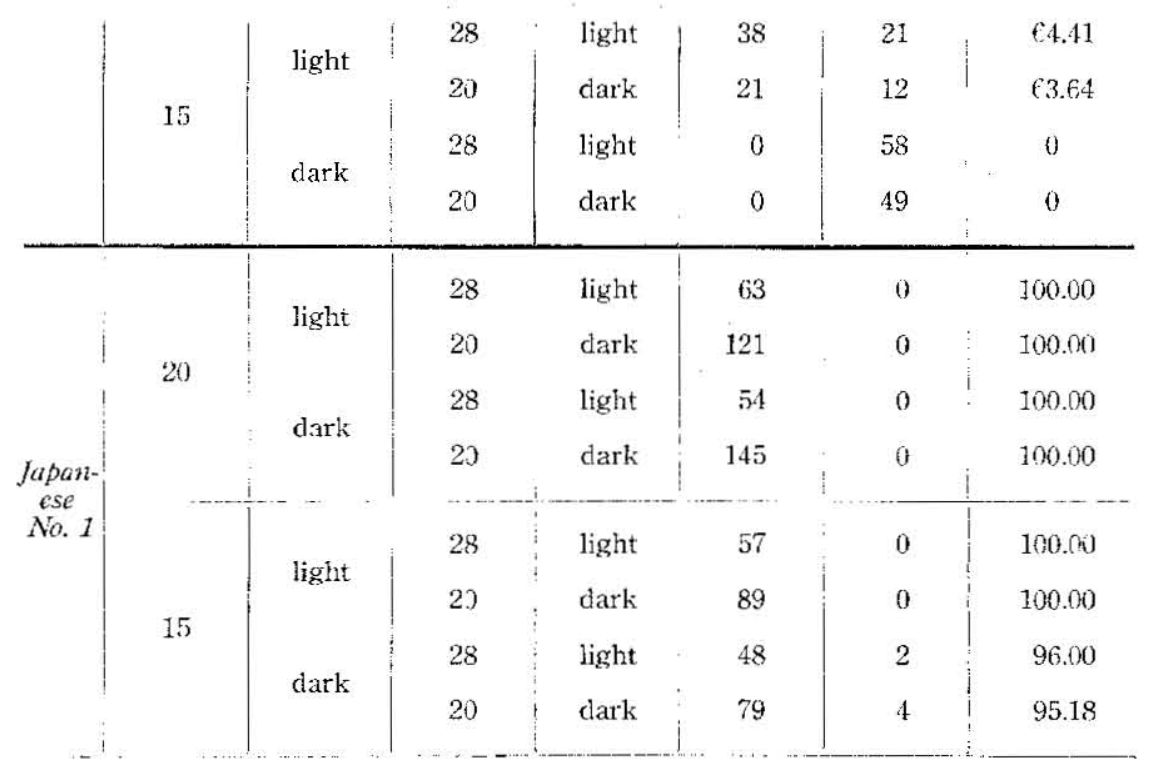

The rcsults in Table 7, for the carlier instars, so far as the effect of light is concerned, stand in fairly close agreement with those in Table 6, the light rearing showing some excess of moths laying dark-colored eggs over those in the dark. The high temperature gave also more dark-colored eggs than did the low temperature. There was a great excess of dark-colored eggs produced at the high temperature and light combined, over those at the low temperature and darkness.

Turning to the effects of light and temperature for incubation and the earlier stadia, much dissimilarity was found in different races regarding voltinism. The infant instars of the bivoltine and tetravoltine were more easily influenced by light and temperature than those of the univoltine. In the case of the bivoltine and tetravoltine, when cggs were incubated at temperatures above $24^{\circ}$ in the light, or at the temperature of $15^{\circ}$ in the dark, no influence was perceived upon producing dark-colored eggs, no matter what the rearing conditions of light and temperature might be. If incubation was carried out at the temperature of $24^{\circ}$ in the dark or at $20^{\circ}$ in the light, much more dark-colored eggs were produced when the infant instars were reared at the high temperature in the light. If the eggs were incubated at $20^{\circ}$ in the dark or $15^{\circ}$ in the light, and the infant instars were reard at the high tem- 
perature in the light, remarkably higher percentages of moths laying dark-colored eggs were obtained, while the percentages among the lots in which light and temperature conditions were directly opposite to one another during the earlier stadia, were nearly equal.

In the univoltine, if eggs were incubated at $15^{\circ}$ in the dark, and the infant instars were reared at the low temperature under the dark condition, they turned a little more numerously into moths laying light-colored eggs. In case of all other conditions of incubation, even if the infant instars werc reared under any favorable conditions of light and temperature, the production of moths laying light-colored eggs was not influenced in the least.

b) Later larval stadia (fourth and fifth instars) For the purpose of investigating the effect of light during the later larval stadia, the larvae of Showa obtained from incubation at $17^{\circ} \mathrm{C}$. in the dark were put in a constant temperature chamber at $28^{\circ} \mathrm{C}$., at the beginning of the fourth stadium, and were divided into four lots; 1) light for the fourth instars, dark for the fifth; 2) light for the fifth instars, dark for the fourth; 3) light throughout both stadia; 4) dark throughout the same period. A similar experiment was performed with Tsunomata. In these experiments,

Table 8

Results of experiments to determine the effect of light during the later larval stadia

\begin{tabular}{|c|c|c|c|c|}
\hline \multirow[b]{2}{*}{ Races } & \multirow[b]{2}{*}{ Light and stadia } & \multicolumn{2}{|c|}{ Number of moths } & \multirow{2}{*}{$\begin{array}{c}\text { Percent. of } \\
\text { moths laying } \\
\text { dark-colored } \\
\text { eggs }\end{array}$} \\
\hline & & $\begin{array}{c}\text { dark-colored } \\
\text { eggs }\end{array}$ & $\begin{array}{l}\text { light-colored } \\
\text { eggs }\end{array}$ & \\
\hline \multirow{4}{*}{ Showa } & stadium 4 light & 67 & 13 & 83.75 \\
\hline & stadium 5 light & 89 & 17 & 83.96 \\
\hline & stadia $4+5$ light & 62 & 16 & 79.49 \\
\hline & stadiat $4+5$ dark & 67 & 10 & 87.01 \\
\hline \multirow{2}{*}{ Tsunomata } & stadia $4+5$ light & 48 & 42 & 53.33 \\
\hline & stadia $4+5$ dark & 31 & 22 & 58.49 \\
\hline
\end{tabular}


the pupal period was cared for in a constant temperature chamber of $20^{\circ} \mathrm{C}$. in the dark (Table 8 ).

The light either in the fourth or in the fifth, stadium resulted in a smaller number of moths laying dark-colorcd cggs than darkness. The effect was more striking when the inscets were exposed to light throughout both stadia.

The next test was performed to determine the interrelation between the effects of light and temperature in the later larval stadia and those during incubation. Eggs and later instars of Shohaku and Tsunomata were treated after the same manner as described for the experiment on the earlier instars.

\section{Table 9}

Effects of light and temperature combined during incubation and the later larval stadia upon the production of moths laying dark-colored eggs

\begin{tabular}{|c|c|c|c|c|c|c|c|}
\hline \multirow[b]{2}{*}{ Races } & \multicolumn{2}{|c|}{$\begin{array}{l}\text { Conditions of } \\
\text { incubation }\end{array}$} & \multicolumn{2}{|c|}{$\begin{array}{c}\text { Conditions of rearing } \\
\text { the later instars }\end{array}$} & \multicolumn{2}{|c|}{ Number of maths } & \multirow{2}{*}{$\begin{array}{l}\text { Percent. of } \\
\text { moths laying } \\
\text { dark-colored } \\
\text { eggs }\end{array}$} \\
\hline & temp. in & $\begin{array}{l}\text { lightt } \\
\text { conditions }\end{array}$ & temp. in & $\begin{array}{c}\text { light } \\
\text { conditions }\end{array}$ & $\begin{array}{l}\text { dark- } \\
\text { colored } \\
\text { eggs }\end{array}$ & $\begin{array}{l}\text { light- } \\
\text { colored } \\
\text { eggs }\end{array}$ & \\
\hline & & light & 28 & $\begin{array}{l}\text { light } \\
\text { dark }\end{array}$ & $\begin{array}{l}184 \\
147\end{array}$ & $\begin{array}{l}0 \\
0\end{array}$ & $\begin{array}{l}100.00 \\
100.00\end{array}$ \\
\hline & & & 20 & $\begin{array}{l}\text { light } \\
\text { darts }\end{array}$ & $\begin{array}{l}130 \\
152\end{array}$ & $\begin{array}{l}0 \\
0\end{array}$ & $\begin{array}{l}100.00 \\
100.00\end{array}$ \\
\hline & 28 & & 28 & $\begin{array}{l}\text { jight } \\
\text { dark }\end{array}$ & $\begin{array}{l}152 \\
138\end{array}$ & $\begin{array}{l}0 \\
0\end{array}$ & $\begin{array}{l}100.00 \\
100.00\end{array}$ \\
\hline & & dark & 20 & $\begin{array}{l}\text { light } \\
\text { dark }\end{array}$ & $\begin{array}{l}174 \\
160\end{array}$ & $\begin{array}{l}0 \\
0\end{array}$ & $\begin{array}{l}100.00 \\
100.00\end{array}$ \\
\hline & & & 28 & $\begin{array}{l}\text { light } \\
\text { dark }\end{array}$ & $\begin{array}{l}1 € 4 \\
137\end{array}$ & $\begin{array}{l}0 \\
0\end{array}$ & $\begin{array}{l}100.00 \\
100.00\end{array}$ \\
\hline & . & & 20 & $\begin{array}{l}\text { light } \\
\text { dark }\end{array}$ & $\begin{array}{l}170 \\
170\end{array}$ & $\stackrel{0}{0}$ & $\begin{array}{l}100.00 \\
100.00\end{array}$ \\
\hline & $2-1$ & & 28 & $\begin{array}{l}\text { light } \\
\text { dark }\end{array}$ & $\begin{array}{l}148 \\
148\end{array}$ & 1 & $\begin{array}{r}99.333 \\
100.00\end{array}$ \\
\hline $\begin{array}{l}\text { Sho- } \\
\text { hakut }\end{array}$ & & dark & 20 & $\begin{array}{l}\text { light } \\
\text { dark }\end{array}$ & $\begin{array}{l}119 \\
120\end{array}$ & 4 & $\begin{array}{r}95.75 \\
100.00\end{array}$ \\
\hline
\end{tabular}


Light and Temperature on Characters of Silkworm

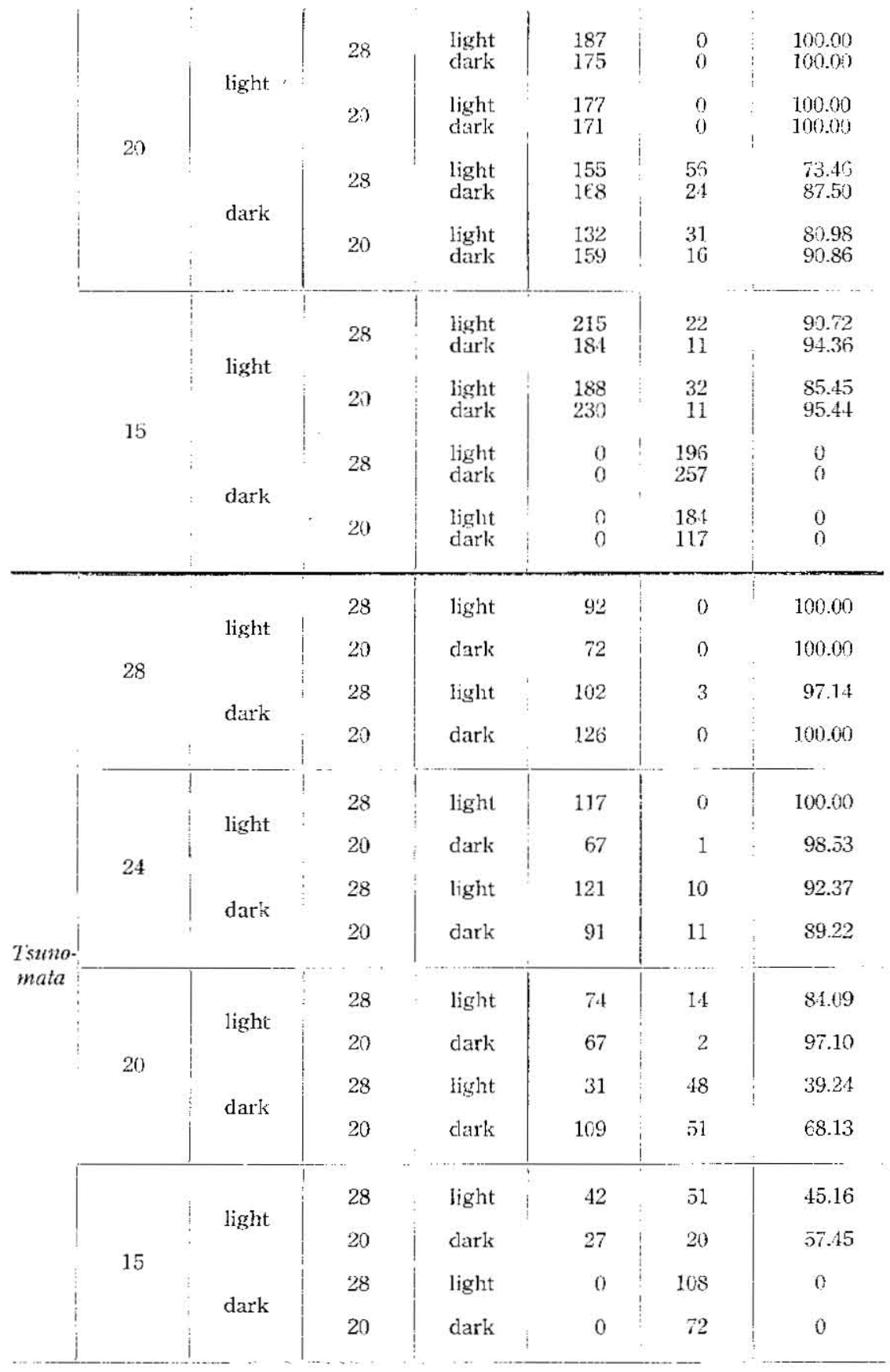


During the later larval stadia light favored the production of moths laying light-colored eggs, and the high temperature also was conducive to it. When the two factors were used in combination, more marked results were obtained.

Light acts in the same way as high temperature during the later larval stadia, though their action is against that during the earlier larval period. If the eggs were incubated at temperatures above $24^{\circ}$ in the light, or at $28^{\circ}$ in the dark, the larvae developed nearly or completely all into moths laying dark-colored eggs, no matter to what light and temperature conditions they were exposed during the larval stadia. If incubated at $15^{\circ}$ in the dark, on the contrary, no effect of light and temperature during the later instars was seen. In the incubation of $20^{\circ}$ and darkness, or of $15^{\circ}$ and light, however, temperature and light led the percentages to decrease and the low temperature and darkness led them to increase.

When light and temperature were opposed to one another, temperature had, other conditions being equal, a greater effect than light.

\section{Pupal Period}

That temperature, during the pupal period, has a contradictory influence on the production of dark-colored eggs as compared with that during the earlier larval stadia has been reported by WATANABE and UMEYA. However, very little evidence of the effect of light has ever been obtained.

Eggs of Shohaku were put into constant temperature chambers at $28^{\circ}, 24^{\circ}, 20^{\circ}$ and $15^{\circ} \mathrm{C}$. for incubation and at each of the temperatures some were kept in the light, others in the dark. Eggs of Tsunomata and Japanese No. $I$ were each separated into four groups, two of which were incubated at $24^{\circ}$ (Tsunomata) or $20^{\circ}$ (Japanese No. I) and two at $15^{\circ} \mathrm{C}$. (both races), and at each temperature one was kept light, the other dark. The pupae were reared at the room temperatures of $28^{\circ}$ and $20^{\circ} \mathrm{C}$., at which they were subjected again to the light and the dark conditions. 
Table 10

Effects of light and temperature combined during the incubation and the pupal periods upon the production of moths laying dark-colored eggs

\begin{tabular}{|c|c|c|c|c|c|c|c|}
\hline \multirow{2}{*}{ Races } & \multicolumn{2}{|c|}{$\begin{array}{l}\text { Conditions of } \\
\text { incubation }\end{array}$} & \multicolumn{2}{|c|}{$\begin{array}{l}\text { Conditions of } \\
\text { treatment for pupae }\end{array}$} & \multicolumn{2}{|c|}{ Number of moths } & \multirow{2}{*}{$\begin{array}{l}\text { Percent, of } \\
\text { moths laying } \\
\text { dark-colored } \\
\text { eggs }\end{array}$} \\
\hline & temp. in & $\begin{array}{l}\text { light } \\
\text { conditions }\end{array}$ & temp. in & $\begin{array}{c}\text { light } \\
\text { conditions }\end{array}$ & $\begin{array}{l}\text { dark- } \\
\text { colored } \\
\text { eggs }\end{array}$ & $\begin{array}{l}\text { Jight- } \\
\text { colored } \\
\text { eggs }\end{array}$ & \\
\hline & & light & 28 & $\begin{array}{l}\text { light } \\
\text { dark }\end{array}$ & $\begin{array}{l}75 \\
59\end{array}$ & $\begin{array}{l}0 \\
0\end{array}$ & $\begin{array}{l}100.00 \\
100.00\end{array}$ \\
\hline & 28 & & 20 & $\begin{array}{l}\text { light } \\
\text { dark }\end{array}$ & $\begin{array}{l}74 \\
66\end{array}$ & $\begin{array}{l}0 \\
0\end{array}$ & $\begin{array}{l}100.00 \\
100.00\end{array}$ \\
\hline & 20 & dark & 28 & $\begin{array}{l}\text { light } \\
\text { dark }\end{array}$ & $\begin{array}{l}89 \\
89\end{array}$ & $\begin{array}{l}0 \\
0\end{array}$ & $\begin{array}{l}100.00 \\
100.00\end{array}$ \\
\hline & & & 20 & $\begin{array}{l}\text { light } \\
\text { dark }\end{array}$ & $\begin{array}{l}82 \\
87\end{array}$ & $\begin{array}{l}0 \\
0\end{array}$ & $\begin{array}{l}100.00 \\
100.00\end{array}$ \\
\hline & & light & 28 & $\begin{array}{l}\text { light } \\
\text { dark }\end{array}$ & $\begin{array}{l}8.3 \\
99\end{array}$ & $\begin{array}{l}0 \\
0\end{array}$ & $\begin{array}{l}100.00 \\
100.00\end{array}$ \\
\hline & 21 & & 20 & $\begin{array}{l}\text { light } \\
\text { dark }\end{array}$ & $\begin{array}{r}114 \\
95\end{array}$ & $\begin{array}{l}0 \\
0\end{array}$ & $\begin{array}{l}100.00 \\
100.00\end{array}$ \\
\hline & 2. & dark & 28 & $\begin{array}{l}\text { light } \\
\text { dark }\end{array}$ & $\begin{array}{l}113 \\
108\end{array}$ & $\begin{array}{l}8 \\
1\end{array}$ & $\begin{array}{l}93.39 \\
99.08\end{array}$ \\
\hline Sho- & & & 20 & $\begin{array}{l}\text { light } \\
\text { dark }\end{array}$ & $\begin{array}{l}136 \\
129\end{array}$ & $\begin{array}{l}2 \\
1\end{array}$ & $\begin{array}{l}98.55 \\
99.23\end{array}$ \\
\hline & & light & 28 & $\begin{array}{l}\text { light } \\
\text { dark }\end{array}$ & $\begin{array}{l}64 \\
67\end{array}$ & $\begin{array}{l}4 \\
0\end{array}$ & $\begin{array}{r}94.12 \\
100.00\end{array}$ \\
\hline & 20 & MSth & 20 & $\begin{array}{l}\text { light } \\
\text { dark }\end{array}$ & $\begin{array}{l}64 \\
66\end{array}$ & $\begin{array}{l}0 \\
0\end{array}$ & $\begin{array}{l}100.00 \\
100.00\end{array}$ \\
\hline & E) & dark & 28 & $\begin{array}{l}\text { light } \\
\text { dark }\end{array}$ & $\begin{array}{l}19 \\
33\end{array}$ & $\begin{array}{l}52 \\
33\end{array}$ & $\begin{array}{l}26.76 \\
50.00\end{array}$ \\
\hline & & & 20 & $\begin{array}{l}\text { light } \\
\text { dark }\end{array}$ & $\begin{array}{l}33 \\
52\end{array}$ & $\begin{array}{l}31 \\
10\end{array}$ & $\begin{array}{l}51.56 \\
83.87\end{array}$ \\
\hline & & & 28 & $\begin{array}{l}\text { light } \\
\text { dark }\end{array}$ & $\begin{array}{l}66 \\
87\end{array}$ & $\begin{array}{l}38 \\
13\end{array}$ & $\begin{array}{l}63.46 \\
87.00\end{array}$ \\
\hline & 1.5 & & 20 & $\begin{array}{l}\text { light } \\
\text { dark }\end{array}$ & $\begin{array}{l}83 \\
90\end{array}$ & $\begin{array}{r}12 \\
8\end{array}$ & $\begin{array}{l}87.37 \\
91.84\end{array}$ \\
\hline & & & 28 & $\begin{array}{l}\text { light } \\
\text { dark }\end{array}$ & $\begin{array}{l}0 \\
0\end{array}$ & $\begin{array}{l}122 \\
110\end{array}$ & $\begin{array}{l}0 \\
0\end{array}$ \\
\hline & & (1) & 20 & $\begin{array}{l}\text { light } \\
\text { dark }\end{array}$ & $\begin{array}{l}0 \\
0\end{array}$ & $\begin{array}{l}91 \\
94\end{array}$ & $\begin{array}{l}0 \\
0\end{array}$ \\
\hline
\end{tabular}




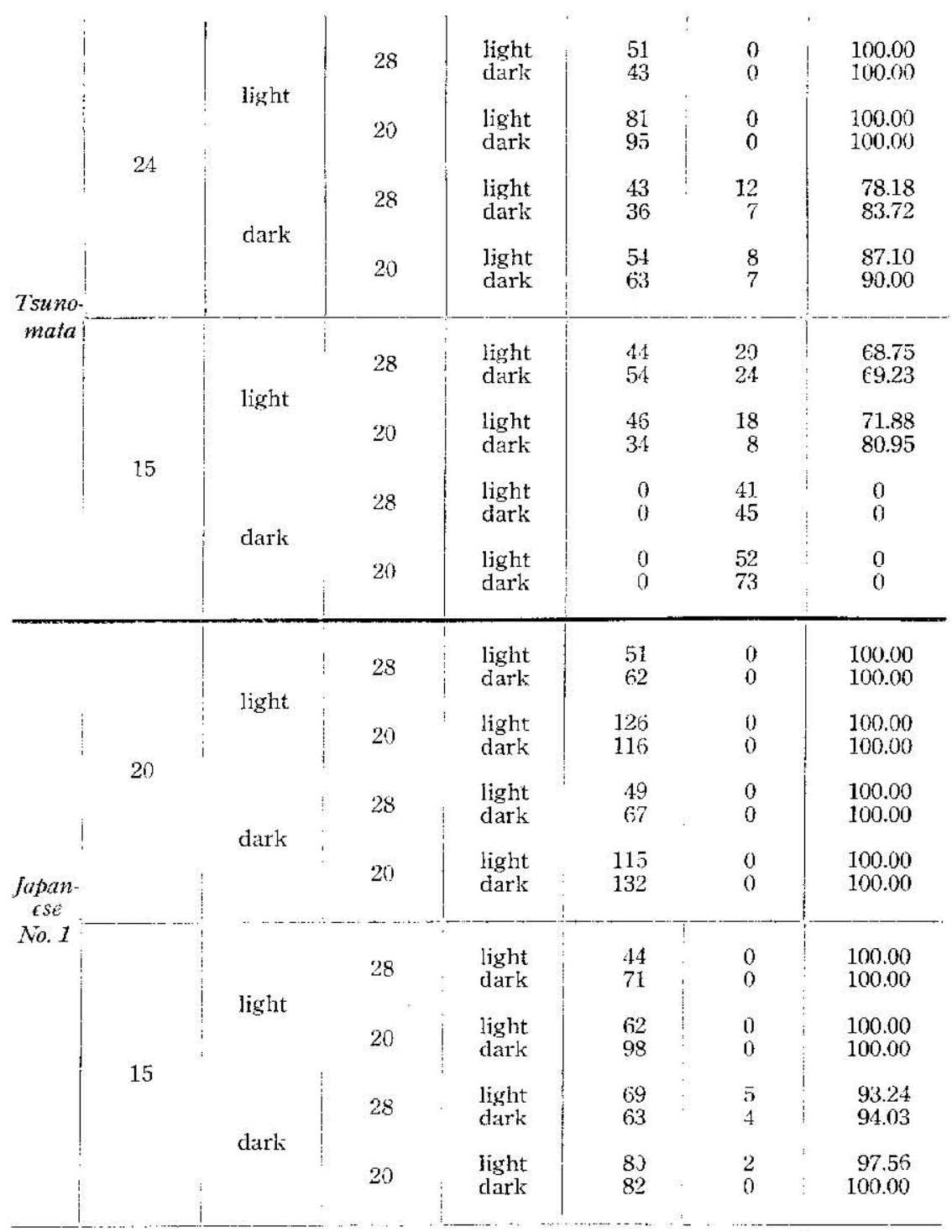

The results indicate that light acted inversely upon the production of dark-colored eggs, compared with the case of the infant instars, and that high temperature acted consistently with light.

In the effects of light and temperature during incubation and those during the pupal stage, a great discrepancy may be found in different types of voltinism. In the bivoltine and tetravoltine, when 
eggs were incubated at temperatures above $24^{\circ}$ in the light, or at $28^{\circ}$ in the dark, the pupae tended no more to be moths laying lightcolored eggs than to be moths laying dark-colored eggs in case of incubation at $15^{\circ}$ in the dark, whatever light and temperature condi tions might be during the pupal period. But if incubated at $20^{\circ}$ in the dark, or at $15^{\circ}$ in the light, the high temperature and light during the pupal period gave lower percentages of moths laying dark-colored eggs, than did either the high temperature and darkness, or the low temperature and light.

In the univoltine race, there was a slight excess of moths laying light-colored eggs at the high temperature in the light over those at the low temperature in darkness only when the eggs were incubated at $15^{\circ}$ in darkness. No excess of them was found under the other conditions of incubation as to light and temperature.

2. Relation between Light and Temperature in producing Moths laying Dark-colored Eggs

A few experiments have been undertaken for the purpose of testing the specific effects of light operative during the incubation and the earlier larval periods, for the reason that light has, at these periods, a strong influence on the production of dark- or lightcolored eggs.

\section{A. Effects of Light Intensity at Different Temperatures}

I took fourteen lots of eggs of Showa, seven of which were incubated at $20^{\circ} \mathrm{C}$, and the other seven at $15^{\circ} \mathrm{C}$. At each of the temperatures, the first lot was covered with a transparent glass plate (light control), the second kept dusky with a frosted glass plate, the third with two such plates, the fourth with three plates, the fifth with five plates, the sixth with seven plates, and the last was kept entirely dark (dark control). The light source, in each room, was Mazda point bulbs of 6 C. P. regulating the potential at 6 volt constantly. The intensity measured at a distance of $3 \mathrm{~m}$. from the source was $0.0256 \mathrm{~F} . \mathrm{C}$. in the first lot, $0.0184 \mathrm{~F} . \mathrm{C}$. in the second, $0.0136 \mathrm{~F} . \mathrm{C}$. in the third, $0.0095 \mathrm{~F} . \mathrm{C}$. in the fourth, 0.0051 F.C. in the fifth and 0.0036 F.C. in the sixth. 
Table 11

Effects of the light intensity during egg incubation upon the production of moths laying dark-colored eggs at different temperatures

\begin{tabular}{|c|c|c|c|c|}
\hline \multicolumn{2}{|c|}{ Conditions of incubation } & \multicolumn{2}{|c|}{ Number of moths } & Percent. of \\
\hline $\begin{array}{l}\text { temp. } \\
\text { in } C .\end{array}$ & light intensity & $\begin{array}{c}\text { dark-colored } \\
\text { eggs }\end{array}$ & $\begin{array}{l}\text { light-colored } \\
\text { eggs }\end{array}$ & $\begin{array}{l}\text { kark-colored } \\
\text { eggs }\end{array}$ \\
\hline \multirow{7}{*}{20} & 1 transparent glass plate & 282 & 4 & 98.60 \\
\hline & 1 frosted glass plate & 164 & 4 & 97.62 \\
\hline & 2 frosted glass plates & 199 & 2 & $99 \cdot 00$ \\
\hline & 3 frosted glass plates & 240 & 4 & 98.36 \\
\hline & 5 frosted glass plates & 142 & 7 & 95.30 \\
\hline & 7 frosted glass plates & 209 & 31 & 87.08 \\
\hline & entire darkness & 217 & 24 & 90.04 \\
\hline \multirow{7}{*}{15} & 1 transparent glass plate & 162 & 45 & 78.26 \\
\hline & 1 frosted glass plate & 181 & 51 & 78.30 \\
\hline & 2 frosted glass plates & 201 & 50 & 8008 \\
\hline & 3 frosted glass plates & 165 & 82 & 66.80 \\
\hline & 5 frosted glass plates & 135 & 102 & 56.96 \\
\hline & 7 frosted glass plates & 76 & 126 & 37.62 \\
\hline & entire darkness & 3 & 145 & 2.03 \\
\hline
\end{tabular}

The influence of the light intensity during the period of incubation upon the percentages is evident and it varies with temperature. At $20^{\circ}$ lower intensities than 0.0051 F.C. (five frosted glass plates) were less favorable to the production of moths laying dark-colored eggs than higher ones, and at the intensity of 0.0095 F.C. (three frosted glass plates) the percentages of moths laying dark-colored eggs were fairly as numerous as at the greater intensities. At $15^{\circ}$, however, above $0.0136 \mathrm{~F} . \mathrm{C}$. (two frosted glass plates) nearly equal percentages resulted, and below 0.0095 F.C. (three frosted glass plates) the fainter the intensity became, the less the percentages were obtained. 
Judging from the mentioned results, the lower light intensity limit for the production of moths laying dark-colored eggs varies with the incubation temperature and the intensity at a low temperature $\left(15^{\circ}\right)$ seems to be a little higher than at a high temperature $\left(20^{\circ}\right)$.

Another experiment was carried out in which eggs were divided into two parts to be incubated at two different constant temperatures, $20^{\circ}$ and $15^{\circ} \mathrm{C}$., and in cach room they were kept at various distances from the light source. The result was that the lower light intensity limit remained nearly the same as shown in the foregoing experiment.

An experiment to test the effects of light during the earlier larval stadia, was done. Eggs of Showa were incubated at the temperature of $17^{\circ} \mathrm{C}$. in the dark. Upon hatching, larvae were separated into five lots; 1) the control covered with a transparent glass plate, the intensity being 0.21 F.C.; 2) covered with a frosted glass plate $(0.15$ F.C.) ; 3) covered with three plates $(0.077$ F.C.) ; 4) covered with seven plates $(0.027$ F.C. $)$; 5) the control kept dark throughout the earlier larval stadia. These intensities of illumination were measured at a distance of $1.8 \mathrm{~m}$. from the light source.

The results are given in Table 12, which show that the intensity of illumination up to 0.15 F.C. (one frosted glass plate) conduced to the production of dark-colored eggs, and that below 0.077 F.C. (three frosted glass plates) was unfavorable to their production. In other words, during the period of feeding, the

Table 12

Effects of the light intensity during the earlier larval stadia upon the production of moths laying dark - colored eggs

\begin{tabular}{l|c|c|c|c}
\hline \multicolumn{1}{c}{ Light intensity } & \multicolumn{2}{c|}{$\begin{array}{c}\text { Number of moths } \\
\text { dark-colored } \\
\text { esgs }\end{array}$} & $\begin{array}{c}\text { light-colored } \\
\text { eggs }\end{array}$ & $\begin{array}{c}\text { Percent. of } \\
\text { moths laying } \\
\text { dark-colored } \\
\text { eggs }\end{array}$ \\
\hline 1 transparent glass plate & 44 & 38 & 53.66 \\
1 frosted glass plate & 46 & 40 & 53.49 \\
3 frosted glass plates & 36 & 51 & 41.38 \\
7 frosted glass plates & 26 & 72 & 26.53 \\
entire darkness & 25 & 55 & 31.25 \\
\hline
\end{tabular}


lower light intensity limit goes up, as a rule, in a certain degree in comparison with that of the incubation period. It has not been made clear whether this is owing to the interruption of light by mulberry leaves or to the lower sensibility in the larva.

\section{B. Effects of Different Wave-lengths of Light at Different Temperatures}

To examine the effects of light of different wave-lengths upon the production of dark-colored eggs during the period of incubation and larval life, glass plates of five different colors, red, orangeyellow, violet, white and dark, of which the tops of the boxes were made, wete used. The red allowed the transmission of rays of wave-lengths below $6100 \AA$, the orange-yellow below $5500 \AA$, and the violet 5100 to $3500 \AA$. The white was a heat-absorbing glass, the transmission range of which was from 7000 to $3500 \AA \tilde{A}$, and the dark was shaded by charcoal paper. At the beginning of the experiment, radiations were measured with an arbitrary unit against the light source of a Mazda daylight lamp. The proportion of the radiation energy was 100 for the red, 312 for the orangeyellow, 200 for the violet, 976 for the heat-absorbing, 0 for the dark, where the red and the orange-yellow were together with heatabsorbing plates. To equalize relatively the total radiation energy through the various colored glass plates, the red was kept at a distance of $0.6 \mathrm{~m}$. from the light source, the orange-yellow $1.0 \mathrm{~m}$., and the violet $0.85 \mathrm{~m}$. The white and dark were kept at a distance of $1.0 \mathrm{~m}$. without regarding the total energy.

Eggs of Showa were divided into ten parts, five of which were placed at a constant temperature room at $20^{\circ} \mathrm{C}$., the other five at $15^{\circ} \mathrm{C}$. At each temperature five were kept separately in different boxes provided with various ray filters as shown above. The light source was a Mazda daylight lamp of 6 vok, 6 C.P. A similar experiment was performed with eggs of the race Tsunomata, in which a Mazda C 2 bulb of 40 watt, keeping 100 volt constantly, was used.

The light intensity under the white (heat-absorbing) glass plate used as the control was 0.3 F. C. in the experiment with Showa, and $3 \mathrm{~F} . \mathrm{C}$. in that with Tsunomata. In these two experiments, the ratio of the amount of light rays of various wave-lengths transmitted through the different plates was about $1: 10$. 
Table 13

Effects of light rays of different filters during the incubation period upon the production of moths laying dark-colored eggs at different temperatures

\begin{tabular}{|c|c|c|c|c|c|}
\hline \multirow[b]{2}{*}{ Races } & \multicolumn{2}{|c|}{ Conditions of incubation } & \multicolumn{2}{|c|}{ Number of moths } & \multirow{2}{*}{$\begin{array}{l}\text { Prrcent. of } \\
\text { moths laying } \\
\text { dark-colored } \\
\text { eggs }\end{array}$} \\
\hline & temp. in & ray filters & $\begin{array}{c}\text { dark-colored } \\
\text { eggs }\end{array}$ & $\begin{array}{c}\text { light-colored } \\
\text { eggs }\end{array}$ & \\
\hline \multirow{10}{*}{ Showa } & \multirow{5}{*}{20} & dark & 274 & 47 & \multirow[t]{5}{*}{85.36} \\
\hline & & red & 261 & 48. & \\
\hline & & orange-yellow & 264 & 19 & \\
\hline & & violet & 269 & 1 & \\
\hline & & white & 341 & 4 & \\
\hline & \multirow{5}{*}{15} & dark & 6 & 205 & 2.84 \\
\hline & & red & 6 & 201 & 2.90 \\
\hline & & orange-yellow & 18 & 216 & 7.69 \\
\hline & & violet & 217 & 5 & 97.75 \\
\hline & & white & 193 & 5 & 97.44 \\
\hline \multirow{10}{*}{$\begin{array}{c}\text { Tsuno- } \\
\text { mata }\end{array}$} & \multirow{5}{*}{20} & dark & 29 & 3 & 93.62 \\
\hline & & red & 60 & 4 & 93.75 \\
\hline & & orange-ye!low & 61 & 2 & 96.83 \\
\hline & & violet & 57 & 0 & 100.00 \\
\hline & & white & 41 & 0 & 100.00 \\
\hline & \multirow{5}{*}{15} & dark & 3 & 100 & 2.91 \\
\hline & & red & 0 & 88 & 0 \\
\hline & & arange-yellow & 13 & 95 & 12.04 \\
\hline & & violet & 95 & 18 & 84.07 \\
\hline & & white & 63 & 19 & 76.83 \\
\hline
\end{tabular}

We learn from these results that different light wave-lengths with nearly equal energy had different effects upon the production of moths laying dark-colored eggs. The red had no more effect than had the dark. The orange-yellow gave results very similar 
to the red, but not exactly the same. The violet as well produced a large number of moths laying dark-colored eggs as the white. These results did neither vary with various incubation temperatures, nor with different amounts of rays as applied to different silkworm races.

In short, the wave-lengths of light below $5500 \AA$, which the orange-yellow plate permits, have little or no effect upon the production of moths laying dark-colored eggs, whilst those above this limit exert a considerable effect on it.

Eggs of Showa were incubated at $17^{\circ} \mathrm{C}$. in the dark, and those of Tsunomata, at $20^{\circ} \mathrm{C}$. in the dark. Upon hatching, they were put into a room at $24^{\circ} \mathrm{C}$., and then separated into five lots. The larvae were treated only during the first and second stadia under five different light conditions, as mentioned in the preceding experiments, and after the third stadium they werc reared similarly. In these experiments, the light source was a Mazda daylight lamp of 40 watt, and the distance was the same as designated above.

The results showed remarkable agreement with those in experiments where eggs were exposed to different rays; the violet as well as the white had a great effect on the production of moths laying dark-colored eggs; the red, orange-yellow as well as the dark were of no effect. Strictly speaking, however, on the occasion of the incubation experiment the orange-yellow showed a slight indication of effectiveness, but not at all in the experiment in the larval period.

\section{Table 14}

Effects of light rays of different filters during the earlier larval stadia upon the production of moths laying dark-colored eggs

\begin{tabular}{|c|c|c|c|c|}
\hline \multirow[b]{2}{*}{ Races } & \multirow[b]{2}{*}{ Ray filters } & \multicolumn{2}{|c|}{ Number of moths } & \multirow{2}{*}{$\begin{array}{l}\text { Percent. of } \\
\text { moths laying } \\
\text { clark-colored } \\
\text { eggs }\end{array}$} \\
\hline & & $\begin{array}{l}\text { dark-colored } \\
\text { eggs }\end{array}$ & $\begin{array}{l}\text { light-culured } \\
\text { eggs }\end{array}$ & \\
\hline \multirow{5}{*}{ Showa } & dark & 28 & 63 & 30.77 \\
\hline & red & 24 & 56 & 30.00 \\
\hline & orange-yellow & 30 & 69 & 30.30 \\
\hline & violet & 50) & 30 & 62.50 \\
\hline & white & 43 & 25 & 63.24 \\
\hline
\end{tabular}




\begin{tabular}{c|c|c|c|c} 
diark & 25 & 79 & 24.04 \\
Tsunomata & 31 & 83 & 27.19 \\
red & 28 & 72 & 28.00 \\
& violet & 51 & 34 & 60.00 \\
& white & 26 & 18 & 59.09 \\
\hline
\end{tabular}

\section{Effects of the Length of Day at Different Temperatures}

As a preliminary to more extensive experiments to determine whether the production of dark-colored eggs could be controlled by the relative length of daily light exposure, numerous trials were carried out. One of them is worth while to be noted. Eighteen egg batches of Showa were divided into nine lots, the first of which was kept in continuous darkness, the second in alternating 3 hours light and 21 hours darkness, for each lot from the third to eighth, light exposure was decreased every day by 3 hours successively, and the ninth lot was kept in continuous light. In the course of the experiment, temperature was kept constantly at $19^{\circ} \mathrm{C}$. The results are recorded in the following table.

Table 15

Effects of the length of day during the period of egg incubation upon the production of moths laying dark-colored eggs

\begin{tabular}{|c|c|c|c|}
\hline \multirow[b]{2}{*}{ Length of day } & \multicolumn{2}{|c|}{ Number of moths } & \multirow{2}{*}{$\begin{array}{c}\text { Percent. of } \\
\text { moths laying } \\
\text { dark-colored } \\
\text { eggs }\end{array}$} \\
\hline & $\begin{array}{c}\text { dark-colored } \\
\text { eggs }\end{array}$ & $\begin{array}{c}\text { light-colored } \\
\text { eggs }\end{array}$ & \\
\hline continuous darkness & 76 & 72 & 51.35 \\
\hline 3 hours light & 82 & 75 & 52.23 \\
\hline 6 hours light & 91 & 81 & 52.91 \\
\hline 9 hours light & 70 & 75 & 48.28 \\
\hline 12 hours light & 92 & 80 & 53.49 \\
\hline 15 hours light & 103 & 11 & 90.35 \\
\hline 18 hours light & 74 & 2 & 97.37 \\
\hline 21 hours light & 86 & 3 & 96.63 \\
\hline continuous light & 93 & 3 & 96.88 \\
\hline
\end{tabular}


No difference was perceptible among the five lots from continuous darkness up to 12 hours exposure, and there very small numbers of moths laying dark-colored eggs were produced. On the other hand, all of the four lots exposed to light for 15 hours or more showed higher percentages without exception, though the lot of 15 hours exposure gave a little lower percentage than any others. This point will be examined further.

Now we come to results of more extensive experiments. Four different tempratures, $28^{\circ}, 24^{\circ}, 20^{\circ}$ and $15^{\circ} \mathrm{C}$. for Shohaku, and two, $25^{\circ}$ and $18^{\circ} \mathrm{C}$. for Tsunomata, were used. At each of the temperatures except $28^{\circ} \mathrm{C}$., twelve lots were established in hourly increasing daily exposure over 12 up to 21 hours. At $28^{\circ} \mathrm{C}$, six lots were set up to increase daily exposure from 12 to 15 hours. Two controls, continuous light and continuous darkness were used in each of these experiments.

\section{Table 16}

Effects of the length of day during the period of incubation upon the production of moths laying dark-colored eggs, in case of more than 12 hours exposure

\begin{tabular}{|c|c|c|c|c|c|}
\hline \multirow[b]{2}{*}{ Races } & \multicolumn{2}{|c|}{ Conditions of incubation } & \multicolumn{2}{|c|}{ Number of moths } & \multirow{2}{*}{$\begin{array}{l}\text { Percent. of } \\
\text { moths laying } \\
\text { dark-colored } \\
\text { eggs }\end{array}$} \\
\hline & temp. in & length of day & $\begin{array}{l}\text { dark- } \\
\text { colored } \\
\text { egggs }\end{array}$ & $\begin{array}{l}\text { light. } \\
\text { colored } \\
\text { eggs }\end{array}$ & \\
\hline & \multirow{6}{*}{28} & continuous darkness & 246 & 0 & 100.00 \\
\hline 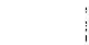 & & 12 hours light & 276 & 3 & 98.92 \\
\hline & & 13 hours light & 251 & 4 & 98.43 \\
\hline & & 14 hours light & 309 & 0 & 100.00 \\
\hline & & 15 hours light & 257 & 0 & 100.00 \\
\hline & & continuous light & 300 & 0 & 100.00 \\
\hline & & continuous darkness & 217 & 15 & 93.53 \\
\hline & & 12 hours light & 229 & 25 & 90.16 \\
\hline & & 13 hours light & 177 & 19 & 90.31 \\
\hline $\mathrm{i}$ & & 14 hours light & 211 & 13 & 94.20 \\
\hline 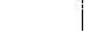 & & 15 hours light & 232 & 0 & 10000 \\
\hline
\end{tabular}




\begin{tabular}{|c|c|c|c|c|c|}
\hline & & 16 hours light & 240 & 0 & 100.00 \\
\hline & 24 & 17 hours light & 245 & 0 & 100.00 \\
\hline & & 18 hours light & 246 & 0 & 100.00 \\
\hline & & 19 hours light & 230 & 0 & 100.00 \\
\hline & & 20 hours light & 195 & 0 & 100.00 \\
\hline & & 21 hours light & 222 & 0 & 100.00 \\
\hline & & continuous light & 232 & 0 & 100.00 \\
\hline haku & & continuous darkness & 52 & 141 & 26.94 \\
\hline & & 12 hours light & 36 & 147 & 19.67 \\
\hline & & 13 hours light & 53 & 118 & 30.99 \\
\hline & & 14 hours light & 76 & 86 & 46.91 \\
\hline 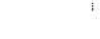 & & 15 hours light & 163 & 14 & 92.09 \\
\hline & & 16 hours light & 135 & 5 & 96.43 \\
\hline & & 17 hours light & 126 & 8 & 94.03 \\
\hline & & 18 hours light & 126 & 2 & 98.44 \\
\hline & & 19 hours lgiht & 169 & 2 & 98.83 \\
\hline & & 20 hours light & 133 & 2 & 98.52 \\
\hline & & 21 hours light & 158 & 3 & 98.14 \\
\hline & & continuous light & 139 & 3 & 97.89 \\
\hline & & continuous darkness & 0 & 190 & 0 \\
\hline & & 12 hours light & 0 & 192 & 0 \\
\hline & & 13 hours light & 0 & 192 & 0 \\
\hline & & 14 hours light & 34 & 183 & 15.67 \\
\hline & & 15 hours light & 79 & 116 & 40.51 \\
\hline & & 16 hours light & 116 & 84 & 58.00 \\
\hline & 10 & 17 hours light & 152 & 68 & 69.09 \\
\hline : & & 18 hours light & 125 & 62 & 66.84 \\
\hline & & 19 hours light & 119 & 50 & 70.41 \\
\hline & & 20 hours light & 148 & 65 & 69.48 \\
\hline & & 21 hours light & 142 & 70 & 66.98 \\
\hline & & continuous light & 1.52 & 65 & 70.05 \\
\hline
\end{tabular}




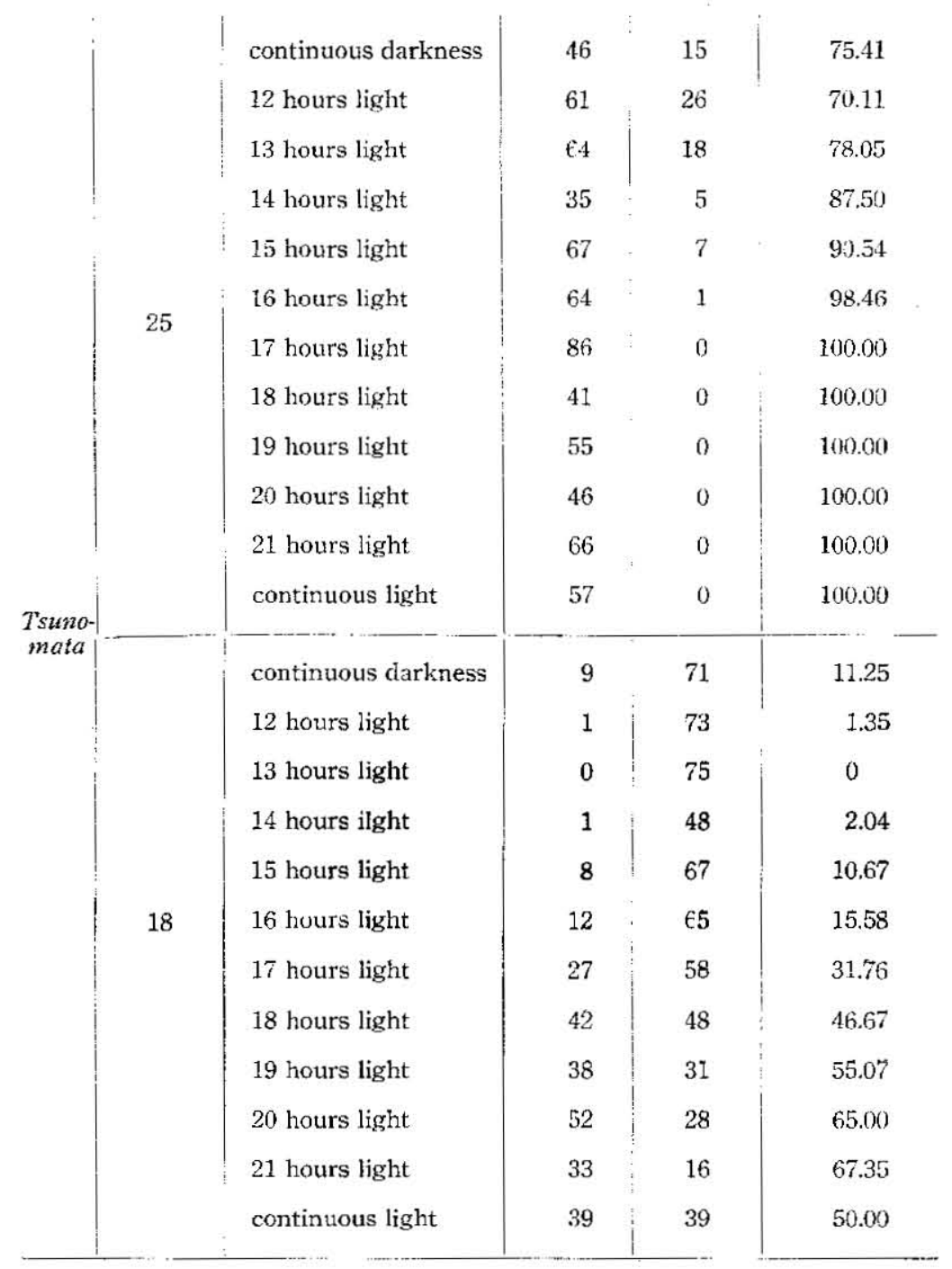

In Shohaku, at $28^{\circ}$ the lot which endured 12 or 13 hours exposure produced only a very small number of moths laying lightcolored eggs, but those of not less than 14 hours exposure produced dark-colored eggs only. Exposure to 15 hours or more produced 100 per cent of moths laying dark-colored eggs at $24^{\circ}$, and 16 hours or more exposure resulted in as many numbers of them as continuous light at $20^{\circ}$. Nevertheless, at the low temperature of $15^{\circ}$, 
more than 17 hours exposure gave rise to about 70 per cent. of moths laying dark-colored eggs. In Tsunomata, more than 16 hours exposure produced a majority of moths laying dark-colored eggs at the high temperature of $25^{\circ}$, and more than 18 hours exposure resulted in 50 per cent, while 12 to 14 hours exposure only a few at $18^{\circ}$. During incubation, 12 or 13 hours exposure did not favor moths laying dark-colored eggs any more than continuous darkness, and a longer exposure was more conducive to their production. The limit of daily exposure, in which an equal number of moths laying dark-colored eggs as that under continuous light were produced, varies by temperature. Between $15^{\circ}$ and $28^{\circ}$, the limit of daily exposure drops by about an hour at every $4^{\circ}$ or $5^{\circ} \mathrm{C}$. rise of temperature.

Eggs of Showa were incubated at $16^{\circ} \mathrm{C}$. in darkness and the first and second instars were put under the following conditions. At each of three differet temperatures, $35^{\circ}, 31^{\circ}$ and $27^{\circ} \mathrm{C}$, five lots were made, the first of which was in continuous darkness, the second in 6 hours exposure, the third in 12 hours, the forth in 18 hours, and the fifth in continuous light. Similarly the eggs of Okusa were incubated at $17^{\circ} \mathrm{C}$. in darkness, and the larvae were reared at $20^{\circ} \mathrm{C}$. in the earlier larval stadia, being separated into nine parts, one in continuous darkness, seven in from 12 to 19 hours exposure every day, and the rest in continuous light.

\section{Table 17}

Effects of the length of day during the earlier larval stadia upon the production of moths laying dark-colored eggs

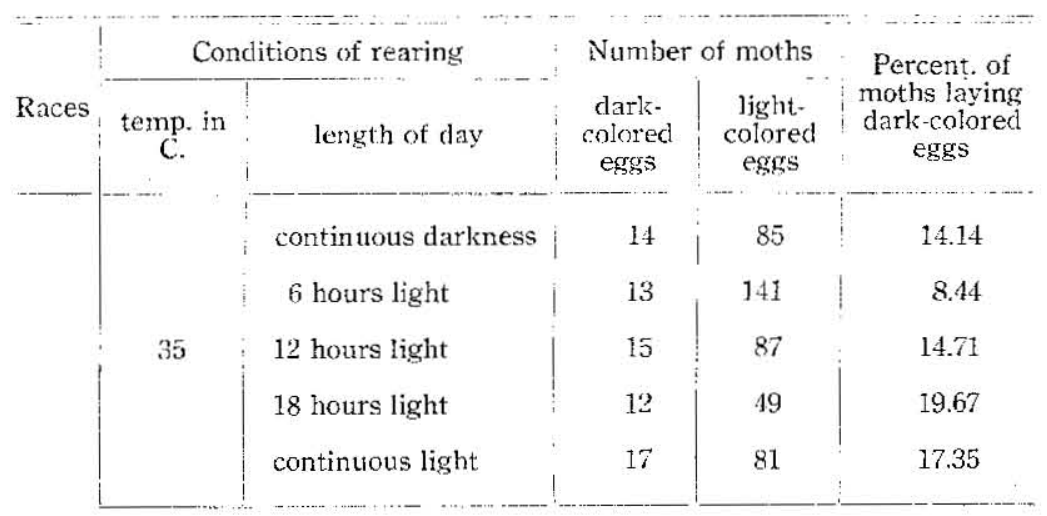




\begin{tabular}{|c|c|c|c|c|c|}
\hline \multirow{10}{*}{ Showa } & \multirow{5}{*}{31} & continuous darkness & 14 & 216 & 6.09 \\
\hline & & 6 hours light & 20 & 182 & 9.90 \\
\hline & & 12 hours light & 11 & 243 & 4.33 \\
\hline & & 18 hours light & 20 & 219 & $8.3 \%$ \\
\hline & & contintuous light & 21 & 172 & 10.88 \\
\hline & \multirow{5}{*}{27} & continuous darkness & 8 & 242 & 3.20 \\
\hline & & 6 hours light & 13 & 270 & 4.59 \\
\hline & & 12 hours light & 1 & 282 & 0.35 \\
\hline & & 18 hours light & 13 & 225 & 5.46 \\
\hline & & continuous light & 17 & 184 & 8.46 \\
\hline \multirow{10}{*}{ Okusa } & \multirow{10}{*}{20} & continuous darkness & 20 & 220 & 10.57 \\
\hline & & 12 hours iight & 18 & 223 & 7.47 \\
\hline & & 13 hours light & 17 & 210 & 7.49 \\
\hline & & 14 hours light & 30 & 264 & 10.20 \\
\hline & & 15 houirs lighi & 43 & 159 & 21.29 \\
\hline & & 16 hours light & 64 & 187 & $25.5 j$ \\
\hline & & 17 hours Ilght & 77 & 165 & 31.82 \\
\hline & & 18 hours light & 100 & 163 & 38.02 \\
\hline & & 19 hours light & 74 & 178 & 29.37 \\
\hline & & continuous light & 106 & 189 & 35.93 \\
\hline
\end{tabular}

The lots exposed for more than 17 or 18 hours during the carlier stadia, produced as many dark-colored eggs as those in continuous light. This is the same result as obtained in the incubation experiment, but in rearing, whether the relative length of daily exposure necessary for producing as many moths laying dark-colored eggs as continuous light does, is changeable by temperatures or not, is uncertain at present. One thing to be noticed in this connection is that a maximum percentage of moths laying light-colored eggs was often attained in 12 hours alternating exposure. This was true in the experiment treated during the incubation as well as in that treated during the larval period, probably 
because of the possible stimulation which alternating light and darkness might give to the material, thus producing more lightcolored eggs than continuous darkness.

3. Effects of Environmental Conditions upon the Production of Mixed Batches

Eggs laid by a single moth are colored, as a rule, either dark or light, except some rare cases where both are mixed in the same batch. These exceptional cases were, however, put out in the foregoing consideration, as they seemed not to affect seriously my conclusion already given. In the "mixed" batches, eggs are deposited in a mass or masses, presenting intermediate colors besides the normal dark violet color and the light one. These intermediate colors were much variable, and the proportion of a definite color has never been determined. Very little account of such a mixed batch has hitherto been published. To ascertain under what conditions they are caused, present experiments were undertaken.

\section{A. Effects of Light and Temperature during the Incutation Period}

In my experiments regarding the effects of light and temperature during incubation upon the production of dark-colored eggs, some mixed batches were found, usually independent of voltinism. The results in Shohaku, Tsunomata and Japanese No. I with reference to the numerical proportion of mixed batches are as follows :

\section{Table 18}

Effects of light and temperature during incubation upon the production of mixed batches

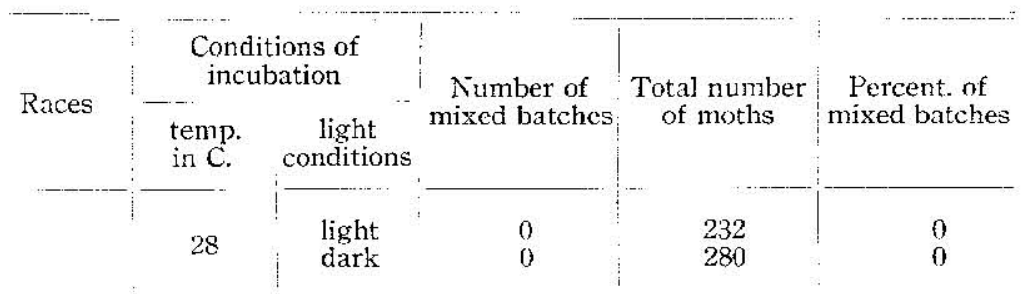




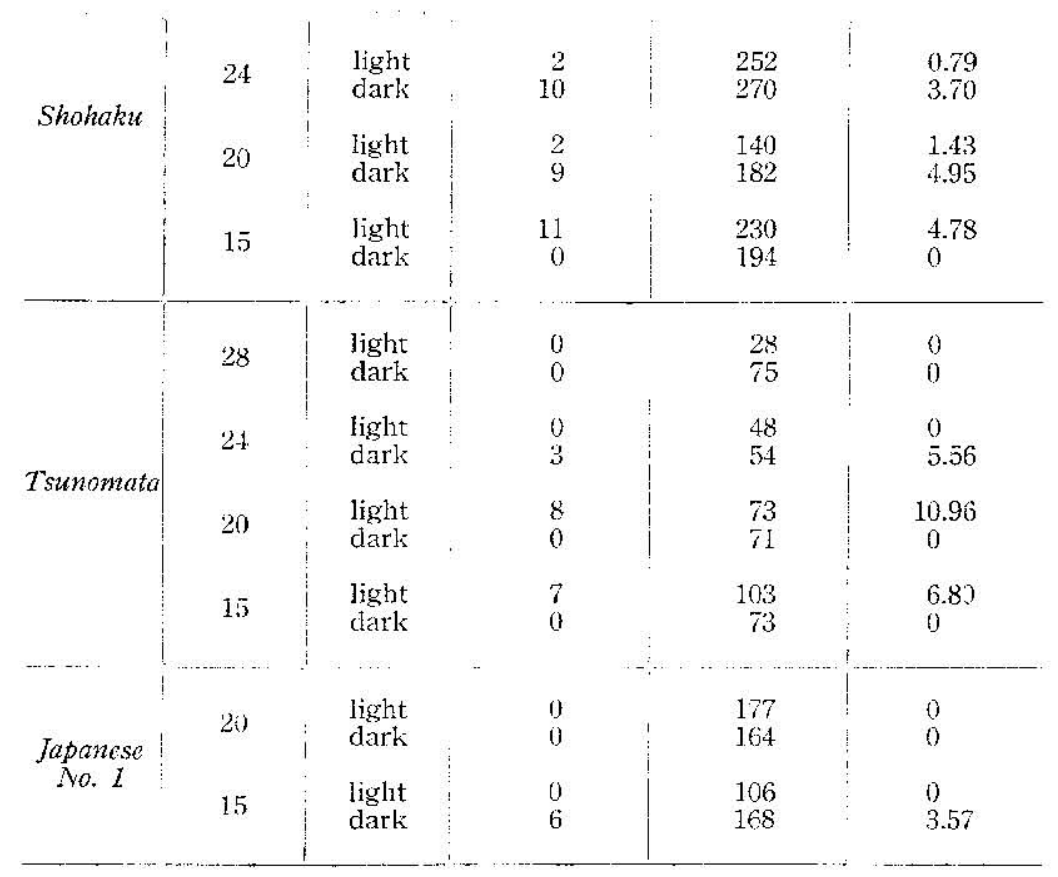

In Shohaku and Tsunomata little larger numbers of mixed batches were found when eggs were incubated under intermediate conditions as to light and temperature. Namely, highest percentages resulted, when the incubation was carried out either at $20^{\circ}$ in the dark, or at $15^{\circ}$ in the light, while incubation at $24^{\circ}$ in the dark, or at $20^{\circ}$ in the light produced lower percentages. Other conditions of light and temperature never induced the production of mixed batches. In Japanese No. 1, a small number of them was obtained at $15^{\circ}$ in the dark, bat nothing under the other conditions.

\section{B. Fffects of Light and Temperature during the Pupal Period}

Although a number of mixed batches may be produced by incubation under intermediate conditions, their percentages are exceedingly variable. This may be attributed to the influence of light and temperature during the pupal period. Two experiments seem to be sufficient to explain this point.

Eggs of Shohaku and Tsunomata were incubated at $20^{\circ} \mathrm{C}$. in the 
dark. After spinning, the pupae were separated into four groups to be subjected to different conditions of light and temperature.

Table 19

Effects of light and temperature during the pupal period upon the production of mixed batches

\begin{tabular}{|c|c|c|c|c|c|}
\hline \multirow{2}{*}{ Races } & \multicolumn{2}{|c|}{$\begin{array}{c}\text { Treatment for } \\
\text { pupae }\end{array}$} & \multirow{2}{*}{$\begin{array}{l}\text { Number of } \\
\text { mixed batches }\end{array}$} & \multirow{2}{*}{$\begin{array}{c}\text { Total number } \\
\text { of batches }\end{array}$} & \multirow{2}{*}{$\begin{array}{l}\text { Percent. of } \\
\text { mixed batches }\end{array}$} \\
\hline & $\begin{array}{l}\text { temp. } \\
\text { in } C \text {. }\end{array}$ & $\begin{array}{c}\text { light } \\
\text { conditions }\end{array}$ & & & \\
\hline \multirow{2}{*}{ Shohaku } & 30 & $\begin{array}{l}\text { light } \\
\text { dark }\end{array}$ & $\begin{array}{r}35 \\
6\end{array}$ & $\begin{array}{l}221 \\
223\end{array}$ & $\begin{array}{r}15.84 \\
2.69\end{array}$ \\
\hline & 20 & $\begin{array}{l}\text { light } \\
\text { dark }\end{array}$ & $\begin{array}{l}2 \\
4\end{array}$ & $\begin{array}{l}280 \\
305\end{array}$ & $\begin{array}{l}0.71 \\
1.31\end{array}$ \\
\hline \multirow{2}{*}{ Tsunomata } & 30 & $\begin{array}{l}\text { light } \\
\text { dark }\end{array}$ & $\begin{array}{l}7 \\
3\end{array}$ & $\begin{array}{l}71 \\
81\end{array}$ & $\begin{array}{l}9.86 \\
3.70\end{array}$ \\
\hline & 20 & $\begin{array}{l}\text { light } \\
\text { dark }\end{array}$ & $\begin{array}{l}2 \\
0\end{array}$ & $\begin{array}{l}66 \\
42\end{array}$ & $\begin{array}{l}3.03 \\
0\end{array}$ \\
\hline
\end{tabular}

It is evident that light and temperature in the pupal period exerted a great influence on producing mixed batches, especially when the two factors were combined in the same direction.

\section{Different Features of the Initial and Final Deposits in Mixed Batches with Reference to Temperature during the Pupal Period}

As mentioned in the preceding section, mixed batches deposit dark-colored, light-colored and intermediate colored eggs, high temperature and light during the pupal period accelerating their production. The following experiment was done for the purpose of knowing if there were any relation between the sequence of oviposition and egg color. When eggs of Showa were incubated at $17^{\circ} \mathrm{C}$. in the dark, the pupae were parcelled out into two groups, one of which was kept at $30^{\circ}$, the other at $20^{\circ} \mathrm{C}$. (both in the light). The moths were allowed to deposit for two hours and the eggs thus obtained are called the first deposit. Then 
they were removed to lay on new sheets of the card-board and left there till the next morning. The eggs obtained during this interval are named as the sccond deposit. These treatments were done for the moths from pupae kept at two different temperatures, $30^{\circ}$ and $20^{\circ} \mathrm{C}$.

Table 20

Mixed batches and the order of deposit according to temperature during the pupal period

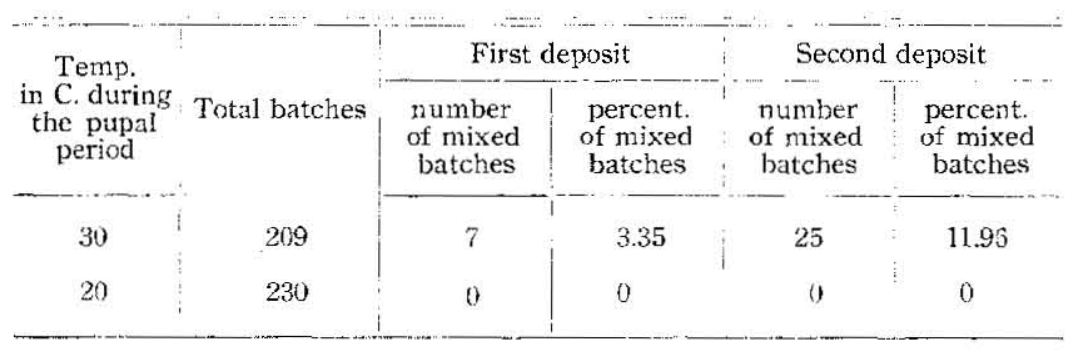

Keeping the pupal period in the high temperature, more mixed batches were produced in the second deposit than in the first one. If the pupae were placed in tha low temperature, neither the first nor the second yielded mixed batches.

\section{Color Grades of Dark- and Light-colored Eggs}

All newly laid eggs are colorless, but some eggs deposit dark violet pigment within the serosa after several days, while some others do not change exceedingly their color, they remaining very light or uncolored. There are considerable variations of color both in dark-colored and light-colored eggs by different temperatures to which they were exposed. Even if temperature was kept the same, still some variations are met with. This fact speaks for the existence of different genetical constitution with respect to the color formation, but this point has not been followed in my present work. An observation on the effect of temperature after egg laying was done by Matsumura (27), who did not come to any definite conclusion. Further knowledge seemed to me urgent, which might not only elucidate the cause of the color variability, but also that of hiberation in the silkworm if possible. 


\section{A. Effects of Temperature upon the Color Variation of Dark-colored Eggs}

Dark-colored eggs are easily distinguishable in the presence of exceedingly dark violet pigment in the serosa from light-colored eggs. The chorion can be slightly tinted yellowish in the darkcolored eggs as compared with the light-colored eggs, although this characteristics is hardly visible in Japanese races.

a) Temperature during the pupal period Pupae of Shohaku, Tsunomata and Japanese No. I were subjected to two different constant temperatures of $30^{\circ}$ and $20^{\circ} \mathrm{C}$. and left, as they were, up to emergence. Eggs laid by the emerging moths were put into a constant temperature. After ten to fifteen days the intensity of egg color was observed.

Table 21

Effects of temperature during the pupal period upon the intensity of egg color

\begin{tabular}{|c|c|c|c|c|c|c|c|c|}
\hline \multirow[b]{2}{*}{ Races } & \multirow{2}{*}{$\begin{array}{l}\text { Temp. } \\
\text { in C. }\end{array}$} & \multirow{2}{*}{$\begin{array}{c}\text { Total } \\
\text { number } \\
\text { of moths }\end{array}$} & \multicolumn{5}{|c|}{ Percent. of moths } & \multirow{2}{*}{$\begin{array}{l}\text { Mean } \\
\text { degree of } \\
\text { cgg color }\end{array}$} \\
\hline & & & eggs & $\underset{\text { eggss }}{+}$ & $\begin{array}{c}\text { t+ } \\
\text { eggs }\end{array}$ & $\begin{array}{c}\text { Ht } \\
\text { eggs }\end{array}$ & $\begin{array}{c}\text { thit } \\
\text { eggs }\end{array}$ & \\
\hline \multirow{2}{*}{ Shohaku } & 30 & 68 & 29.41 & 60.29 & 10.30 & 0 & 0 & $t$ \\
\hline & 20 & 147 & 1.46 & 19.71 & 24.82 & 43.80 & 10.21 & $\mathrm{H} \sim \mathrm{H}$ \\
\hline \multirow{2}{*}{ Tsunemata } & 30 & 32 & 0 & 12.50 & 43.75 & 43.75 & 0 & $\mathrm{H} \sim \mathrm{Ht}$ \\
\hline & 20 & 49 & 0 & 2.04 & 16.33 & 48.98 & 32.65 & $\mathrm{HH} \sim \mathrm{H} H$ \\
\hline \multirow{2}{*}{$\begin{array}{c}\text { Japanese } \\
\text { No. } 1\end{array}$} & 30 & 110 & 10.91 & 21.82 & 61.82 & 5.45 & 0 & $+\sim H$ \\
\hline & 20 & 241 & 0 & 3.73 & 18.67 & 36.10 & 11.50 & $\mathrm{HH} \sim \mathrm{HH}$ \\
\hline
\end{tabular}

Symbol - indicates the least intensive color, Ht the most intensive and others the intermediate colors in order.

It was found that when the pupae were kept at the high temperature of $30^{\circ}$, their eggs became fainter in color than eggs from the pupae kept at the low temperature of $20^{\circ}$. No significant difference in variability was seen between those two experimental series. 
b) Temperature after the time of laying New-laid eggs from somc moths of bivoltine, tetravoltine and univoltine races were divided and put into six different constant temperatures, $30^{\circ}, 25^{\circ}$, $20^{\circ}, 15^{\circ}, 13^{\circ}$ and $11^{\circ} \mathrm{C}$. When twenty days had elapsed after laying the eggs were drawn out from the given temperatures, and placed at $25^{\circ} \mathrm{C}$. for five days, then the intensity of egg color was examined.

Table 22

Effects of temperature upon the intensity of egg color after the time of egg laying

\begin{tabular}{l|c|cc|c|c|c}
\hline \hline $\begin{array}{l}\text { Temp. in } \mathrm{C} . \\
\begin{array}{c}\text { Mean degree of } \\
\text { egg color }\end{array}\end{array}$ & $\begin{array}{c}30 \\
\mathrm{H}\end{array}$ & 25 & 20 & 15 & 13 & 11 \\
\hline
\end{tabular}

The greatest amount of pigment developed at $15^{\circ}$ and $20^{\circ}$. The farther the temperature went up or down from these degees, the less the amount of pigment came out.

Hereupon, to ascertain how long eggs must be kept under the optimum temperature of $15^{\circ} \mathrm{C}$. to produce a maximum amount of pigment, another trial was performed. New-laid eggs of Showa were separated into six parts and kept at $15^{\circ} \mathrm{C}$. They were brought out into the temperature of $30^{\circ} \mathrm{C}$. every day one by one.

Table 23

Relation between the number of days placed at $15^{\circ} \mathrm{C}$. and the intensity of egg color

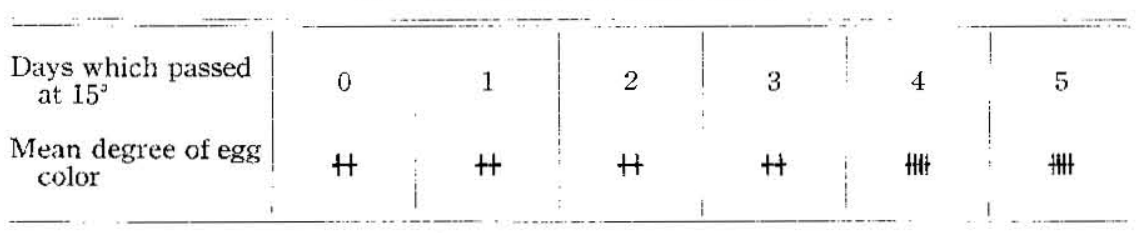

Eggs kept at $15^{\circ}$ for four days or more manifested most intensive color, whereas those kept at $30^{\circ}$ less intensive one. This phenomenon was true in any different races as to voltinism. 


\section{B. Effects of Temperature upon the Color Variation of Light-colored Iiggs}

It has been observed by some investigators that light-colored eggs could be more or less strongly colored when treated with a temperature lower than $5^{\circ} \mathrm{C}$. According to my experiments, this coloration is merely due to the change of color of the yolk which is caused to degenerate by a low temperature. I, therefore, put eggs into temperatures higher than $10^{\circ} \mathrm{C}$. to avoid the yolk degeneration, and studied the variation of the serosa color of light-colored eggs affected by temperature cluring the pupal period and after egg laying. The least intensive had but little amount of pigment, while the most was as darkly pigmented as brown. The intensity of egg color was classified into five grades.

a) Temperature during the pupal period. On spinning, the larvae from the incubation at a $10 \mathrm{w}$ temperature of $15^{\circ} \mathrm{C}$. in the dark, were divided into two groups, one was kept at $30^{\circ}$ and other at $20^{\circ} \mathrm{C}$. The moths were made to lay in the temperature of $13^{\circ}$ or $20^{\circ} \mathrm{C}$. The intensity of egg color was observed after twenty-five days.

Table 24

Effects of temperature during the pupal period upon the intensity of egg color

\begin{tabular}{|c|c|c|c|c|c|c|c|c|}
\hline \multirow[b]{2}{*}{ Races } & \multirow{2}{*}{$\begin{array}{l}\text { Temp. } \\
\text { in C. }\end{array}$} & \multirow{2}{*}{$\begin{array}{c}\text { Total } \\
\text { number } \\
\text { of moths }\end{array}$} & \multicolumn{5}{|c|}{ Percent. of moths } & \multirow{2}{*}{$\begin{array}{c}\text { Mean } \\
\text { degree of } \\
\text { egg color }\end{array}$} \\
\hline & & & $\frac{-}{\operatorname{cggs}}$ & $\stackrel{+}{\operatorname{cggs}}$ & $\begin{array}{c}\text { H } \\
\text { cggs }\end{array}$ & $\begin{array}{c}\text { tit } \\
\text { eggs }\end{array}$ & $\begin{array}{l}\text { Htt } \\
\text { eggs }\end{array}$ & \\
\hline \multirow{2}{*}{ Showa } & 30 & 484 & 0 & 1.44 & 14.67 & 42.36 & 41.53 & $\mathrm{Ht} \sim \mathrm{HHH}$ \\
\hline & 20 & 616 & 46.91 & 24.03 & 13.31 & 15.75 & 0 & $-\sim+$ \\
\hline \multirow{2}{*}{ Tsunomata } & 30 & 86 & 0 & 0 & 2.33 & 19.77 & 77.90 & HH \\
\hline & 20 & 79 & 0 & 1.27 & 5.05 & 20.25 & 73.43 & tHt \\
\hline
\end{tabular}

In Shohaku, temperature during the pupal period proved an important factor; at the high temperature the eggs deposited greater amount of pigment than at the low temperature. In the 
case of Tsunomata, on the other hand, temperature did not play any important rôle for changing the intensity of egg color.

b) Temperature after egg laying. Newly laid eggs to be lightcolored eggs were parcelled out into six lots and put into constant temperature chambers at $30^{\circ}, 25^{\circ}, 20^{\circ}, 15^{\circ}, 13^{\circ}$ and $11^{\circ} \mathrm{C}$. Two lots of these which were placed at $25^{\circ}$ and $30^{\circ}$, were left there for three days, the one lot at $20^{\circ}$ was left there for five days, the one at $15^{\circ}$ for fifteen days, and the one at $11^{\circ}$ for twenty days, and then they were all transferred to $13^{\circ} \mathrm{C}$. The intensity of egg color was investigated on the twenty-fifth day after egg laying.

Table 25

Effects of temperature after the time of egg laying upon the intensity of egg color

\begin{tabular}{|c|c|c|c|c|c|c|}
\hline Temp. in C. & 30) & 25 & 20 & 15 & 13 & 11 \\
\hline $\begin{array}{l}\text { Mean degree of } \\
\text { egg color }\end{array}$ & - & - & $-\sim+$ & tt & $\mathrm{Ht}$ & $H H \sim$ HH \\
\hline
\end{tabular}

The result shown in the above table is much different from those in the case of the dark-colored eggs. As the lower temperature used, the more intensive the egg color grew.

Another experiment was carried out in order to ascertain the number of days needed to pass at $13^{\circ} \mathrm{C}$. to cause the eggs to become more intensive. Eggs of Showa were divided into six parts, four of which werc kept at $13^{\circ}$ and were removed into $25^{\circ} \mathrm{C}$. every five days. Among the remaining two parts, the one was kept at $13^{\circ}$ and the other at $25^{\circ}$ from the beginning of the experiment. The intensity of egg color was examined on the thirtieth day after laying.

Table 26

Relation between the number of days which passed at $13^{\circ} \mathrm{C}$. and the intensity of egg color

\begin{tabular}{l|ccccccc}
$\begin{array}{l}\text { Days which passed } \\
\text { at } 13^{\circ}\end{array}$ & 0 & 5 & 10 & 15 & 20 & 25 \\
$\begin{array}{l}\text { Mean degree of egg } \\
\text { color }\end{array}$ & - & $+\sim \mathrm{H}$ & $\mathrm{H} \sim \mathrm{Ht}$ & $\mathrm{H} \sim \mathrm{Ht}$ & $\mathrm{H} \sim \mathrm{HH}$ & $\mathrm{H} \sim \mathrm{HH}$ \\
\hline
\end{tabular}


Eggs placed at $13^{\circ}$ for five days put on color to some degrec, while those kept at that temperature for more than ten days produced a considerable deal of pigment. These results harmonize with the fact that the serosa formation takes two or three days at a high temperature such as $25^{\circ}$, but lakes about ten days at a low temperature of $13^{\circ}$.

It is worthy of consideration that color variation caused by temperature is limited to the light-colored eggs of the bivoltine and univoltine races, but no pigment increases in those of the tetravoltine race.

\section{Hibernation of Dark- and Light-colored Eggs}

As stated previously, dark-colored eggs lie dormant, as a rule, while the light-colored do not. This, however, does not hold true for tetravoltine races, since WATANABE successfully changed a majority, even all, of dark-colored eggs of the tetravoltine into non-hibernating eggs by means of controlling the environmental factors, especially temperature. Dark-colored eggs of the bivoltine and univoltine have also been sometimes observed to become nonhibernating. On the other hand, light-colored eggs have been believed never to be turned into hibernating eggs. I have, however, succeeded in modifying some of the light-colored into hibernating eggs, especially in those of the bivoltine and univoltine. Consequently, it is possible to say that hibernation is not always determined by whether the eggs are colored darked or not, but is partly determined by other conditions such as temperature. Hibernating or non-hibernating eggs occurring in the dark-colored or light-colored are scattered irregularly within the same batch, their proportion being very variable by different batches even if they were kept under uniform environmental conditions.

\section{Production of Non-hibernating Fggs out of the Dark-colored}

In order to ascertain the period when the external agent works most efficiently upon the production of non-hibernating eggs out of the dark-colored, a great many trials were performed. Some more important results are given below. 


\section{A. Effects of Light and Temperature during Incubation}

It has been believed by WATANABE ('24) that producing nonhibernating eggs out of the dark-colored depends upon temperature during incubation, that is, a higher degree of their production is followed by incubation at an intermediate temperature $\left(20^{\circ}\right)$ than that at a higher temperature $\left(25^{\circ} \mathrm{C}\right.$.). The results of my experiments are somewhat different from this.

The races Shohaku, Showa, Tsunomata and Japanese No. 1 were used as materials. Light and temperature during incubation were varied according to races used; Shohaku and Showa were kept at $20^{\circ}$ and $25^{\circ} \mathrm{C}$. in the light and the dark, respectively, Tsunomata at $20^{\circ}$ in the light and the dark, and Japanese No. 1 at $15^{\circ} \mathrm{C}$. in the light and the dark. After egg laying all the lots were kept at $25^{\circ}$ or $30^{\circ} \mathrm{C}$. for about a month, and then left at the room temperature till the winter, when non-hibernating eggs were examined.

Table 27

Effects of light and temperature during incubation upon the production of non-hibernating eggs out of the dark-colored

\begin{tabular}{|c|c|c|c|c|}
\hline \multirow{2}{*}{ Races } & \multicolumn{2}{|c|}{$\begin{array}{l}\text { Conditions of } \\
\text { incubation }\end{array}$} & \multirow{2}{*}{$\begin{array}{l}\text { Total number } \\
\text { of dark-colored } \\
\text { egg batches }\end{array}$} & \multirow{2}{*}{$\begin{array}{l}\text { Mean percent. of } \\
\text { non-hibernating eggs }\end{array}$} \\
\hline & $\begin{array}{l}\text { temp. } \\
\text { in C. }\end{array}$ & $\begin{array}{l}\text { light } \\
\text { conditions }\end{array}$ & & \\
\hline \multirow{2}{*}{ Shohaku } & 20 & $\begin{array}{l}\text { light } \\
\text { dark }\end{array}$ & $\begin{array}{l}483 \\
517\end{array}$ & $\begin{array}{l}1.35 \pm 0.15 \\
1.83 \pm 0.18\end{array}$ \\
\hline & 25 & $\begin{array}{l}\text { light } \\
\text { dark }\end{array}$ & $\begin{array}{l}410 \\
453\end{array}$ & $\begin{array}{l}1.91 \pm 0.24 \\
1.90 \pm 0.18\end{array}$ \\
\hline \multirow{2}{*}{ Showa } & 20 & $\begin{array}{l}\text { light } \\
\text { dark }\end{array}$ & $\begin{array}{l}354 \\
176\end{array}$ & $\begin{array}{l}1.98 \pm 0.21 \\
2.50 \pm 0.39\end{array}$ \\
\hline & 25 & $\begin{array}{l}\text { light } \\
\text { dark }\end{array}$ & $\begin{array}{l}257 \\
281\end{array}$ & $\begin{array}{l}2.68 \pm 0.37 \\
2.51 \pm 0.34\end{array}$ \\
\hline \multirow{2}{*}{ Isunomata } & \multirow{2}{*}{20} & light & 164 & $18.13 \pm 1.31$ \\
\hline & & clark & 111 & $20.05 \pm 1.66$ \\
\hline
\end{tabular}


Light and Temperature on Characters of Silkworm

\begin{tabular}{cc:c|cc}
$\begin{array}{c}\text { Japancse } \\
\text { No. } 1\end{array}$ & 15 & light & 154 & $0.25 \pm 0.05$ \\
& & dark & 157 & $0.13 \pm 0.04$ \\
\hline
\end{tabular}

Table 27 shows that light and temperature during the incubation period have nothing to do with the production of nonhibernating eggs out of the dark-colored.

\section{B. Effects of Temperature during the Pupal Period}

WATANABE discovered in the tetravoltine that many more dark-colored eggs are turned into non-hibernating eggs when kept at a higher temperature during the pupal period. My experiments were planned to pursue the influence of temperature upon the occurrence of non-hibernating eggs out of the dark-colored in the bivoltine, univoltine as well as the tetravoltine. The pupae were divided into two groups, one of which was kept at a temperature of $30^{\circ}$ or $28^{\circ}$, the other $20^{\circ} \mathrm{C}$, and the eggs laid were placed at $25^{\circ} \mathrm{C}$.

Table 28

Effects of temperature during the pupal period upon the production of non-hibnerating eggs out of the dark-colored

\begin{tabular}{c|c|c|c}
\hline \multirow{2}{*}{ Races } & Temp. in C. & $\begin{array}{c}\text { Total number of } \\
\text { dark-colored egg } \\
\text { batches }\end{array}$ & $\begin{array}{c}\text { Mean percent. of } \\
\text { non-hibernating } \\
\text { eggs }\end{array}$ \\
\hline Shohaku & 30 & 251 & $0.20 \pm 0.04$ \\
& 20 & 410 & $1.91 \pm 0.24$ \\
\hline Showa & 30 & 535 & $0.23 \pm 0.04$ \\
& 20 & 655 & $2.00 \pm 0.21$ \\
\hline Tsunomata & 28 & 60 & $98.07 \pm 0.57$ \\
\hline \multirow{2}{*}{ Japancse } & 20 & 111 & $20.05 \pm 1.66$ \\
No. I & 30 & 120 & $0.08 \pm 0.02$ \\
\hline
\end{tabular}


The data from these experiments show that the pupal stage was one of the periods most sensible for environmental conditions which might operate to make eggs non-hibernating, and that temperature was an important agent in this connection. It is also evident that the effect of temperature was not the same in different races, namely, the low temperature gave a larger yield of non-hibernating eggs than the high temperature in bivoltine and univoltine races, while the high temperature resulted in a larger number of non-hibernating eggs than the low temperature in the tetravoltine in which the numerical proportion for both temperatures was exceedingly high as compared with that in others.

\section{Effects of Temperature after the Time of Egg Laying}

As temperature was kept at $25^{\circ} \mathrm{C}$. after the time of egg laying, in the experiments above mentioned, it may be suspected if the temperature had an influence upon the production of nonhibernating eggs in the egg period. To clear up this point the following test was made. Eggs of bivoltine Shohaku, the parental pupae of which were raised at a low temperature of $20^{\circ} \mathrm{C}$. were parcelled out into five parts and put into different temperatures, $30^{\circ}, 25^{\circ}, 20^{\circ}, 15^{\circ}$ and $13^{\circ} \mathrm{C}$, respectively immediately after laying. In tetravoltine Tsunomata, whose pupae had passed at a high temperature of $30^{\circ} \mathrm{C}$, the eggs laid were divided into four parts and put into four different temperatures, the same except $13^{\circ}$ as in the foregoing series. Eggs of univoltine Japanese No. 1 from the pupae which had been kept at $20^{\circ} \mathrm{C}$., were treated in a similar manner to Tsunomata. In each series, the lots kept at $25^{\circ}$ were removed into $30^{\circ}$ after three days, those kept at $20^{\circ}$ after five days, those kept at $15^{\circ}$ after eight days, and those kept at $13^{\circ}$ after fifteen days. The lots kept at $30^{\circ}$ and those removed from lower temperatures were left for a month as they were, and then they were returned to the natural environmental conditions. The investigation in the winter offerred the following results.

\section{Table 29}

Effects of temperature after the time of egg laying upon the production of non-hibernating eggs 


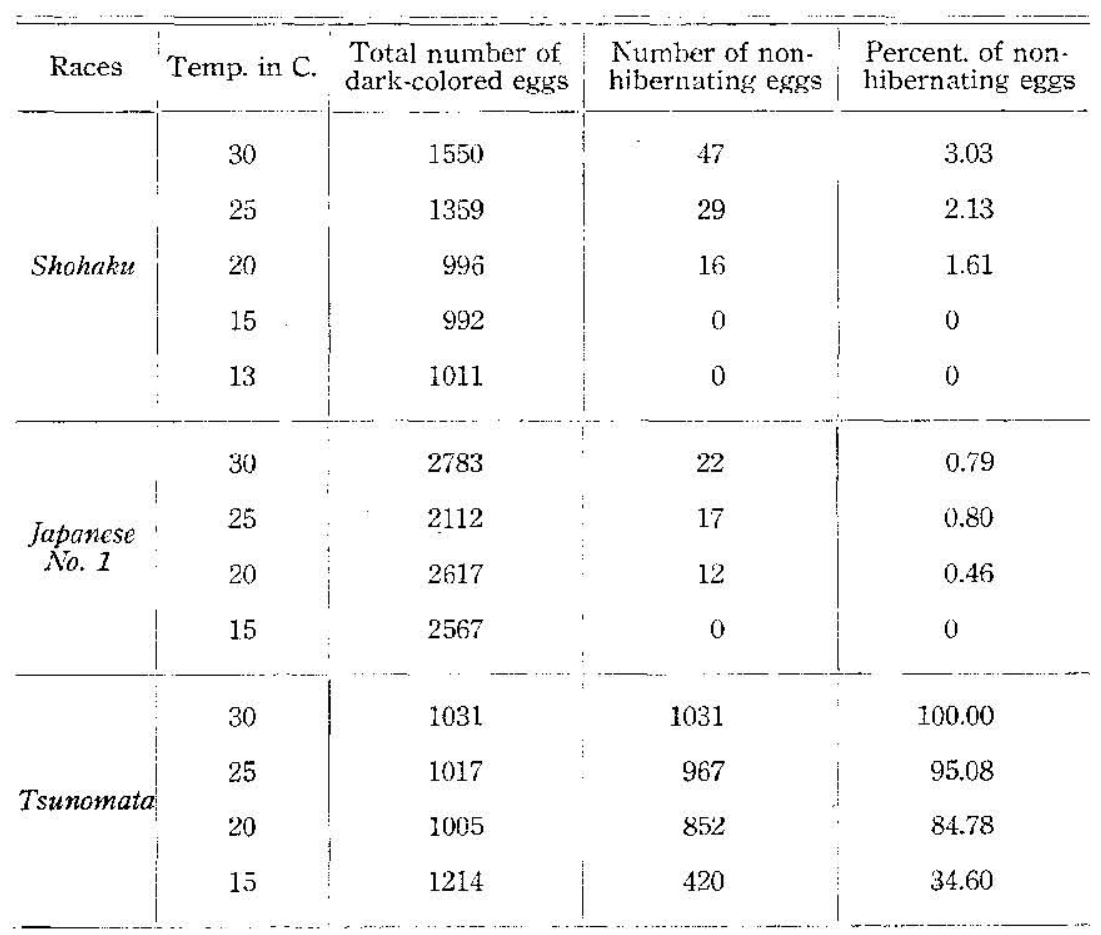

As shown in Table 29, all the races experimented, changed a considerable number of dark-colored eggs into non-hibernating ones, increasing the number with temperature, although the percentages in the bivoltine and univoltine were much less than those in the tetravoltine. The high temperature of $30^{\circ}$ was able to make all eggs non-hibernating in the tetravoltine. On the contrary, all eggs were made hibernating in the bivoltine and univoltine at the low temperature of $15^{\circ}$ or $13^{\circ}$.

In the foregoing experiment, dark-colored eggs of the bivoltine and univoltine were never turned into non-hibernating eggs, provided that eggs were kept either at $15^{\circ} \mathrm{C}$. as long as for eight days, or at $13^{\circ} \mathrm{C}$. for fifteen days. We might harbor a doubt that if they had been left at such low temperatures for a longer time, some of the dark-colored eggs might have turned into nonhibernating ones. The answer to this question is obtained from the following experiment, in which eggs of Showa were kept for forty days at five different temperatures, and then brought to natural conditions. 
Table 30

Effects of temperature when eggs were kept for forty days at five different temperatures

\begin{tabular}{c|c|c|c}
\hline $\begin{array}{c}\text { Temp. } \\
\text { in C. }\end{array}$ & $\begin{array}{c}\text { Total number of } \\
\text { dark-colored eggs }\end{array}$ & $\begin{array}{c}\text { Number of non- } \\
\text { hibernating cggs }\end{array}$ & $\begin{array}{c}\text { Percent. of non- } \\
\text { hibernating eggs }\end{array}$ \\
\cline { 1 - 3 } 30 & 2240 & 74 & 3.30 \\
25 & 2423 & 58 & 2.39 \\
20 & 2080 & 22 & 1.06 \\
15 & 2529 & 130 & 5.14 \\
13 & 2823 & 711 & 25.19 \\
\hline
\end{tabular}

When eggs were kept for forty days after laying at different temperatures, an increasing number of non-hibernating eggs was obtained with decreasing temperature below $20 .^{\circ}$

Eggs of Showa were parcelled out into six lots; one lot was placed in a constant temperature chamber of $25^{\circ} \mathrm{C}$. and the other five were put in at $15^{\circ} \mathrm{C}$. and each of five lots was later removed into $25^{\circ}$ at 12 hours, one day, two days, three days, or four days, respectively after egg laving. One more trial was carried out in an opposite way, namely, that six lots were removed from $25^{\circ}$ into $13^{\circ} \mathrm{C}$., and they were kept there as long as for forty days.

Table 31

The period to be affected by temperature after laying, in the dark-colored eggs

\begin{tabular}{|l|l|c|c|c|}
\hline $\begin{array}{c}\text { Mani- } \\
\text { pulation }\end{array}$ & $\begin{array}{c}\text { Time when lots } \\
\text { were removed }\end{array}$ & $\begin{array}{c}\text { Total number of } \\
\text { dark-colored eggs }\end{array}$ & $\begin{array}{c}\text { Number of non- } \\
\text { hibernating eggs }\end{array}$ & $\begin{array}{c}\text { Percent of non } \\
\text { hibernating eggs }\end{array}$ \\
\hdashline & immediately & 2267 & 72 & 3.18 \\
& 12 hours & 2318 & 59 & 25.5 \\
from $15^{\circ}$ & one day & 2620 & 18 & 0.69 \\
into $25^{\circ}$ & two days & 2860 & 7 & 0.24 \\
& three days & 2621 & 0 & 0 \\
& four days & 2716 & 0 & 0 \\
& & & &
\end{tabular}




\begin{tabular}{l|l|l|l|l} 
& immediately & 4298 & 408 & 9.49 \\
from $25^{\circ}$ & 12 hours & 4376 & 408 & 9.32 \\
into $13^{\circ}$ & one day & 4396 & 337 & 7.67 \\
& two days & 4388 & 42 & 0.96 \\
three days & 4462 & 8 & 0.18 \\
four days & 4321 & 1 & 0.23 \\
\hline
\end{tabular}

In the first trial, eggs removed from $15^{\circ}$ into $25^{\circ}$ at the end of three days, become all hibernating. In the second trial, the lots removed from $25^{\circ}$ into $13^{\circ}$ within a day after laying, resulted in rather large numbers of non-hibernating eggs. We know thus that the effective period for the occurrence of the non-hibernating eggs extends over two or three days after deposition.

In another test, eggs of Showa and Tsunomata, the parental pupae of which were kept at two different temperatures, $30^{\circ}$ and $20^{\circ} \mathrm{C}$., were put in a temperature chamber of $13^{\circ} \mathrm{C}$. and divided into two parts, one was left there for fifteen days and the other for forty days. Then the eggs were brought into $25^{\circ} \mathrm{C}$., and after a month they were exposed to the room temperature till the winter, when the number of non-hibernating eggs out of the dark-colored were counted.

Table 32

Effects of temperature during the pupal period with special reference to the duration to keep the eggs at $13^{\circ} \mathrm{C}$.

\begin{tabular}{|c|c|c|c|c|c|}
\hline Races & $\begin{array}{l}\text { Temp. in C. } \\
\text { during the } \\
\text { pupal period }\end{array}$ & $\begin{array}{c}\text { Duration } \\
\text { in days } \\
\text { at } 13^{\circ}\end{array}$ & $\begin{array}{c}\text { Total number } \\
\text { of dark- } \\
\text { colored eggs }\end{array}$ & $\begin{array}{l}\text { Number of } \\
\text { non-hibernat- } \\
\text { ing eggs }\end{array}$ & $\begin{array}{c}\text { Percent. of } \\
\text { non-hibernat- } \\
\text { ing eggs }\end{array}$ \\
\hline \multirow{4}{*}{ Showa } & \multirow{3}{*}{30} & 15 & 2603 & 0 & 0 \\
\hline & & 40 & 3048 & 311 & 10.20 \\
\hline & & 15 & 2596 & 1 & 0.04 \\
\hline & 20 & 40 & 2491 & 468 & 18.79 \\
\hline
\end{tabular}




\begin{tabular}{|c|c|c|c|c|c|}
\hline \multirow{4}{*}{$\begin{array}{l}\text { Tsuno- } \\
\text { mata }\end{array}$} & \multirow{3}{*}{30} & 15 & 8091 & 382 & 4.72 \\
\hline & & 40 & 8564 & 3067 & 35.81 \\
\hline & & 15 & 8797 & 2 & 0.02 \\
\hline & 20 & 40 & 8969 & 2115 & 23.58 \\
\hline
\end{tabular}

In Showa, the eggs of short duration never turned out to be non-hibernatíng eggs, while those of long duration produced a large number of them, although they were more abundant in the lots which were kept at the low temperature during the pupal period than those at the high temperature. In Tsunomata, when the pupal period was kept at the low temperature, a smaller number resulted than at the high temperature. But it was found concerning duration that a decidedly larger number of non-hibernating eggs resulted in long duration than in short duration.

2. Production of Ilibernating Eggs out of the Light-colored

It has been believed that light-colored eggs are by no means capable of hibernation. This is probably because the eggs had been exposed to a comparatively high temperature after deposition, and not treated with a low temperature, or they had been, if any, treated too late. I have succeeded in ascertaining that temperature during the pupal period and immediately after egg laying make some light-colored eggs hibernate.

\section{A. Effects of Temperalure during the Pupal Period}

Pupae of Shohaku, Showa, Tsunomata and European No.9, were subjected to a high $\left(28^{\circ}\right.$ or $30^{\circ} \mathrm{C}$.) and a low $\left(20^{\circ} \mathrm{C}\right.$.) temperatures throughout the pupal period. Immediately after laying, eggs of each race were kept at $13^{\circ} \mathrm{C}$. as long as fifteen or twenty days. In the winter, the hibernating eggs were examined; the results are given below.

Table 33

Effects of temperature during the pupal period upon the production of hibernating eggs out of the light-colored 
Light and Temperature on Characters of Silkworm

\begin{tabular}{|c|c|c|c|}
\hline Races & Temp. in C. & $\begin{array}{c}\text { Total number of } \\
\text { light-colored } \\
\text { batches }\end{array}$ & $\begin{array}{l}\text { Mean percent. of } \\
\text { hibernating eggs }\end{array}$ \\
\hline \multirow{2}{*}{ Shohaku } & 28 & 149 & $16.81 \pm 1.36$ \\
\hline & 20 & 153 & $7.14 \pm 0.83$ \\
\hline \multirow{2}{*}{ Showa } & 30 & 481 & $28.75 \pm 0.87$ \\
\hline & 20 & 616 & $16.71 \pm 0.65$ \\
\hline \multirow{2}{*}{ Tsunomata } & 30 & 97 & $0.26 \pm 0.08$ \\
\hline & 20 & 122 & $2.39 \pm 0.58$ \\
\hline \multirow{2}{*}{ European No. 9} & 30 & 19 & 62.58 \\
\hline & 20 & 5 & 41.87 \\
\hline
\end{tabular}

It is clearly shown in the table that temperature during the pupal period stands in close connection with the occurrence of hibernating eggs. The percentages of hibernating eggs and effects of temperature upon them were, however, much different by races. In'Shohaku, Showa and European No. 9, the low temperature favored the occurrence of non-hibernating eggs, while the high temperature conduced to hibernation. This relation was reversed in Tsunomata.

\section{B. Effects of Temperature after the Time of Egg Laying}

Since the eggs were kept at $13^{\circ} \mathrm{C}$. after laying in the foregoing experiments, temperature during this period might have affected the production of hibernating eggs. To elucidate this point, eggs of Showa and Tsunomata were divided into six (in Showa) or five parts (in Tsunomata) immediately after laying. Each part of Showa was at once brought into different chambers of $30^{\circ}, 25^{\circ}, 20^{\circ}, 15^{\circ}$, $13^{\circ}$ and $11^{\circ} \mathrm{C}$. Each lot of Tsunomata was put into one of the same temperature chambers, except $11^{\circ} \mathrm{C}$. as in Showa. In both cases, cggs in $11^{\circ}$ were conveyed into the $25^{\circ}$ chamber after twenty days, those in $13^{\circ}$ after fifteen days, those in $15^{\circ}$ after ten days, those in $20^{\circ}$ after five days, and those in $30^{\circ}$ after three days. They were placed there for thirty days. 
Table 34

Effects of temperature after the time of egg laying upon the production of hibernating eggs

\begin{tabular}{|c|c|c|c|c|}
\hline Races & Temp. in $\mathrm{C}$. & $\begin{array}{l}\text { Total number of } \\
\text { light-colored eggs }\end{array}$ & $\begin{array}{c}\text { Number of } \\
\text { hibernating eggs }\end{array}$ & $\begin{array}{c}\text { Percent. of } \\
\text { hibernating eggs }\end{array}$ \\
\hline \multirow{6}{*}{ Showa } & 30 & 878 & 0 & 0 \\
\hline & 25 & 875 & 0 & 0 \\
\hline & 20 & 922 & 3 & 0.33 \\
\hline & 15 & 958 & 108 & 11.27 \\
\hline & 13 & 923 & 554 & 60.02 \\
\hline & 11 & 901. & 901 & 100.00 \\
\hline \multirow{5}{*}{ Tsunomata } & 30 & 2002 & 0 & 0 \\
\hline & 25 & 1943 & 0 & 0 \\
\hline & 20 & 2266 & 0 & 0 \\
\hline & 15 & 2424 & 40 & 1.65 \\
\hline & 13 & 2181 & 148 & 6.79 \\
\hline
\end{tabular}

The information to be obtained from this table is that lower temperatures gave more production of hibernating eggs, and the percentages were different in two races, being higher in Showa than in Tsinomata.

To examine how long the susceptible period does last, eggs of Nisshin were divided into six parts at once aftcr laying, and kept for five, ten, fifteen, twenty, thirty or forty days, respectively, in a chamber at $13^{\circ} \mathrm{C}$. As a result, the lot of fifteen days attained the highest percentage, while those of either shorter or longer duration than this gave rise to lower percentages (Table 35).

A test was performed to detect the developmental stage of the embryo which is most sensitive for the production of hibernating eggs. Eggs of Showa were laid in a $25^{\circ} \mathrm{C}$. chamber and they were parcelled out into five lots; the first was brought immediately after laying, the second at 12 hours, and others every day, into $13^{\circ} \mathrm{C}$. All the lots were removed again into the $25^{\circ}$ chamber after twenty days (Table 36). 
Table 35

Effects of the number of days kept at $13^{\circ} \mathrm{C}$. upon the production of hibernating eggs

\begin{tabular}{|c|ccc}
$\begin{array}{c}\text { Number of days } \\
\text { at } 13^{2}\end{array}$ & $\begin{array}{c}\text { Total number of } \\
\text { light-colored eggs }\end{array}$ & $\begin{array}{c}\text { Number of } \\
\text { hibernating eggs }\end{array}$ & $\begin{array}{c}\text { Percent. of } \\
\text { hibernating eggs }\end{array}$ \\
\hline 5 & 1938 & 0 & 0 \\
10 & 2037 & 293 & 14.53 \\
15 & 1841 & 471 & 25.58 \\
20 & 1788 & 409 & 22.88 \\
30 & 1695 & 269 & 15.87 \\
40 & 1828 & 113 & 6.18 \\
\hline
\end{tabular}

Table 36

The period to be affected by temperature after laying, in the light-colored eggs

\begin{tabular}{l|c|cc}
$\begin{array}{c}\text { Time when lots } \\
\text { were removed } \\
\text { into } 13^{5}\end{array}$ & $\begin{array}{c}\text { Total number of } \\
\text { light-colored eggs }\end{array}$ & $\begin{array}{c}\text { Number of } \\
\text { libernating eggs }\end{array}$ & $\begin{array}{c}\text { Percent. of } \\
\text { hibernating eggs }\end{array}$ \\
\hdashline immediately & 1979 & 943 & 17.65 \\
12 hours & 2355 & 886 & 37.62 \\
one day & 2461 & 268 & 10.89 \\
two days & 2117 & 28 & 1.32 \\
three days & 2242 & 0 & 0 \\
\end{tabular}

The occurrence of hibernating eggs was less numerous when older cmbryos were exposed to the low temperature, in the lots at $25^{\circ}$ for two days or more, little or no hibernating eggs resulted. Thus we know that the production of hibernating eggs out of the light-colored depends upon temperature in pupal and egg periods, and in the egg period, the first two days only being susceptible to the temperature effect. 


\section{General Consideration of Hibernation and Egg Color in the Silkworm Eggs}

\section{Problem of Hibernation}

Several hypotheses on the phenomenon of hibernation or dormancy of insects have hitherto been presented by many authors, such as Roubard ('22), TOWNSEND ('26), PARKer and Thompson ('27), Shelford ('27), SpoONer ('27), and Robinson ('29). But none of them is, it seems to me, sufficient to explain the very complex phenomenon in question.

Concerning the silkworm a physico-chemical explanation has been made public by WATANABE and UMEYA. WATANABE ('24) took granted the existence of an "inhibitory substance" in the eggs destined to hibernate, which UMEYA ('26) called a "voltinism-determiner." On the other hand, I believe in the presence of two distinct substances, i.e., a "first hibernation substance" and a "second hibernation substance," the former being analogous to the inhibitory substance or voltinism-determiner of the enumerated authors.

The first hibernation substance principally determines egg color, i.e., dark- or light-colored, but it exerts, at the same time, a considerable effect on the hibernating character. While the second hibernation substance has chiefly to do with hibernation of eggs, it affects also egg color. The first hibernation substance is affected by light and temperature during the incubation, larval and pupal periods, while the second hibernation substance is influenced by temperature only after pupation.

\section{On the First Hibernation Substance}

The effects of light and temperature upon the production of

the dark- and light-colored eggs, will be summarized with reference to the different types of voltinism, in the following table.

Table 37

The production of the dark- and light-colored eggs as influenced by light and temperature 
Light and Temperature on Characters of Silkworm

\begin{tabular}{|c|c|c|c|c|}
\hline Voltinism & $\begin{array}{l}\text { Conditions } \\
\text { during } \\
\text { incubation }\end{array}$ & $\begin{array}{l}\text { Conditions } \\
\text { during the } \\
\text { earlier stadia }\end{array}$ & $\begin{array}{l}\text { Conditions during } \\
\text { the later larval } \\
\text { and pupal periods }\end{array}$ & Results \\
\hline \multirow{3}{*}{ Bivoltine } & $\begin{array}{l}28^{3} \text {, daxk } \\
24^{\circ}, \text { light }\end{array}$ & $\begin{array}{l}\text { high, light } \\
\text { low, dark }\end{array}$ & $\begin{array}{l}\text { low, dark } \\
\text { high, light }\end{array}$ & $\begin{array}{l}\text { dark-colored eggs only } \\
\text { dark-colored eggs only }\end{array}$ \\
\hline & $\begin{array}{l}20^{\circ} \text {, dark } \\
15^{\circ} \text {, light }\end{array}$ & $\begin{array}{l}\text { high, light } \\
\text { low, dark }\end{array}$ & $\begin{array}{l}\text { low, dark } \\
\text { high, light }\end{array}$ & $\begin{array}{l}\text { daris-colored (more) and } \\
\text { light-colored (less) eggs } \\
\text { dark-colored (less) and } \\
\text { light-colored (more) eggs }\end{array}$ \\
\hline & $15^{\circ}$, dark & $\begin{array}{l}\text { high, light } \\
\text { low, dark, }\end{array}$ & $\begin{array}{l}\text { low, dark } \\
\text { high, light }\end{array}$ & $\begin{array}{l}\text { light-colored eggs only } \\
\text { light-colored eggs only }\end{array}$ \\
\hline \multirow{3}{*}{$\begin{array}{l}\text { Tetra- } \\
\text { voltine }\end{array}$} & $\begin{array}{l}28^{\circ} \text {, dark } \\
24^{\circ} \text {, light }\end{array}$ & $\begin{array}{l}\text { high, light } \\
\text { low, dark }\end{array}$ & $\begin{array}{l}\text { low, dark } \\
\text { high, light }\end{array}$ & $\begin{array}{l}\text { dark-colored eggs only } \\
\text { dark-colored eggs only }\end{array}$ \\
\hline & $\begin{array}{l}20^{\circ} \text {, dark } \\
15^{\prime}, \text { light }\end{array}$ & $\begin{array}{l}\text { high, light } \\
\text { low, dark }\end{array}$ & $\begin{array}{l}\text { low, clark } \\
\text { high, light }\end{array}$ & $\begin{array}{l}\text { dark-colored (more) and } \\
\text { light-colored (less) eggs } \\
\text { dark-colored (less) and } \\
\text { light-colored (more) eggs }\end{array}$ \\
\hline & $15^{\circ}$, dark & $\begin{array}{l}\text { high, light } \\
\text { low, dark }\end{array}$ & $\begin{array}{l}\text { low, dark } \\
\text { high, light }\end{array}$ & $\begin{array}{l}\text { light-colored egrgs only } \\
\text { light-colored eggs only }\end{array}$ \\
\hline \multirow[b]{2}{*}{ Univoltine } & $\begin{array}{l}20^{\circ}, \text { dark } \\
15^{\circ}, \text { light }\end{array}$ & $\begin{array}{l}\text { high, Jight } \\
\text { low, dark }\end{array}$ & $\begin{array}{l}\text { low, dark } \\
\text { high, light }\end{array}$ & $\begin{array}{l}\text { datk-colored eggs only } \\
\text { dark-colored eggs only }\end{array}$ \\
\hline & $15^{2}$, dark & $\begin{array}{l}\text { high, light } \\
\text { Low, dark }\end{array}$ & $\begin{array}{l}\text { low, dark } \\
\text { high, light }\end{array}$ & $\begin{array}{l}\text { dark-colored (majority) and } \\
\text { light-colored ia few) eggs } \\
\text { dark-colored (somewhat } \\
\text { less) and light-colored } \\
\text { (somewhat more) eggs }\end{array}$ \\
\hline
\end{tabular}

"High" designates a temperature of $30^{\circ}$ or $28^{\circ}$ and "low," $20^{\circ} \mathrm{C}$. "Light" shows an intensity of light of about 0.5 F.C. and "dark-" perfect darkness.

Either embryos, larvae or pupae which have a definite deal of the first hibernation substance develop into moths laying darkcolored eggs, while those which have none or a little of it develop into moths laying light-colored eggs.

There are distinct racial characteristics with respect to the first hibernation substance. In the bivoltine and tetravoltine, the substance is produced abundantly only by means of the light and the high temperature incubation, while the univoltine has 
plenty of it as shown in the fact that this race usually gives rise to a complete number of moths laying dark-colored eggs at any incubation temperature, except $15^{\circ} \mathrm{C}$. in the dark. If eggs of the bivoltine and tetravoltine are incubated under the intermediate conditions $\left(20^{\circ}\right.$ dark or $15^{\circ} \mathrm{C}$. light), and those of the univoltine at $15^{\circ}$ in the dark, two kinds of moths, one laying dark-colored and the other laying light-colored eggs, are produced. The first hibernation substance does not seem to be produced in these cases, sufficiently to cause all moths to lay dark-colored eggs, for some of them lay light-colored eggs, owing to the individual variations of amount of the substance. The individuals provided with a medium amount of the substance are affected by the environmental conditions after hatching. Namely, if they were reared either at high temperature in the light during the earlier larval stadia or at low temperature in the dark during the later larval and pupal stages, more moths laying dark-colored eggs result.

As stated previously, the distinction between the dark-colored and the light-colored is clear, notwithstanding the fact that among one kind slight variations of the coloration can be found. It may be said, therefore, that there is a limit of the amount of the substance above which the dark-colored occur, while below it the light-colored are produced.

The environmental stimuli during both the incubation and the earlier larval periods, can be regarded as working in the same direction; high temperature and light resulting in a greater amount of the substance, their effects are at a maximum at the stage from the blastokinesis to the tracheal formation of the embryo, dccreasing gradually up to the end of the third larval stadium. In the pointed stage of the embryo, blood cells differentiate from the mesoderm and increase in number suddenly. Both the incubation period and the carlier larval stadia may be called, so to speak, an "anabolic" period for the substance, accumulating in the body fiuid of the silkworm through the effect of high tem. perature and light.

Next we come to the first hibernation substance during the later larval stadia and pupal period. This period is affected by environmental stimuli as follows:-Low temperature and darkness favor the production of moths laying dark-colored eggs, but high temperature and light do not. WATANABE believes in an accelerated 
production of the inhibitory substance by low temperature and no effectiveness of high temperature in this point. I am, however, of the opinion that low temperature and darkness during this period never accelerate the production of the substance in the body fluid, but high temperature and light tend to destroy it. In other words, the later period of the life history of the silkworm may possibly be indicated as a "catabolic" period. In explanation of my opinion that the individuals which might accumulate a definite amount of the substance by virtue of high temperature and light during the egg and the earlier larval stages, no longer increase the amount during the later larval and the pupal life by low temperature and darkness, but reduce it under high temperature and light, the following data are presented.

a) The mixed batches are produced under the intermediate conditions during incubation and in the case where pupae are kept at high temperature in the light. The eggs in the egg-tubes, develop from the lower parts toward the termini successively during the pupal period. The majority of pupae developed from the eggs which were under the intermediate conditions of incubation, should lie near the critical boundary to become moths laying either dark- or light-colored eggs, so that light and temperature, during the maturation period of egg-cells, may cause the occurrence of the mixed batches. Even the individuals which carry a sufficient quantity of the substance to lay dark-colored eggs in the anabolic period, under high temperature and light in the catabolic period, may be turned into moths laying the mixed batches, by making the final deposit light-colored, the earlier deposit being dark-colored. Even if low temperature and darkness might be kept throughout pupal period, the individuals having the smaller quantity of the substance could produce by no means the mixed batches, because low temperature and darkness could never increase the amount of the substance during that period.

b) The color grades of the dark-colored cggs are much infuenced by temperature during the pupal period and after egg laying. After laying, the temperature range from $15^{\circ}$ to $20^{\circ} \mathrm{C}$. has been found most effective to make the egg color more intensive, as the temperature goes up or down the farther from that range, the less grows the intensity of egg color, and the effective period is confined to two or threc days after laying. 
It is possible that when pupae are kept at high temperature, those which have a smaller quantity of the first hibernation substance are apt to turn into moths laying light-colored eggs, and those which contain larger amount lay the dark-colored ones, but they are less intensive in color as comparcd with those kept at low temperature. These results run parallel to MATSUMURA's observation that tyrosinase in blood of the silkworm larvae is greatest in its action at $15^{\circ}$ or $20^{\circ} \mathrm{C}$., and it grows weaker and weaker according to the degree of divergence from those optimum temperatures.

\section{On the Second Hibernation Substance}

The occurrence of hibernating or non-hibernating eggs out of the dark-colored or light-colored has been announced. The numerial rate varies with temperature after pupation. The different rates of non-hibernating eggs out of the dark-colored and those of hibernating eggs out of the light-colored may be tabulated as follows :

\section{Table 38}

Comparison of the proportion of hibernating or non-hibernating eggs out of the dark- or light-colored as influenced by temperature

\begin{tabular}{|c|c|c|c|c|}
\hline Voltinism & $\begin{array}{c}\text { Temperature } \\
\text { during the } \\
\text { pupal period }\end{array}$ & $\begin{array}{l}\text { Temperature } \\
\text { after egg } \\
\text { laying }\end{array}$ & $\begin{array}{l}\text { Proportion of } \\
\text { non-hibernating } \\
\text { eggs out of the } \\
\text { dark-colored }\end{array}$ & $\begin{array}{l}\text { Proportion of } \\
\text { hibernating eggs } \\
\text { out of the } \\
\text { light-colored }\end{array}$ \\
\hline \multirow{4}{*}{ Bivoltine } & \multirow{2}{*}{ high } & high & + & - \\
\hline & & low & - & $\mathrm{HH}$ \\
\hline & \multirow{2}{*}{ low } & high & H & - \\
\hline & & low & - & H \\
\hline \multirow{4}{*}{ Tetravoltine } & \multirow{2}{*}{ hight } & high & Hth & - \\
\hline & & low & + & - \\
\hline & \multirow[b]{2}{*}{ low } & high & $\mathrm{HH}$ & - \\
\hline & & $10 \mathrm{w}$ & - & + \\
\hline
\end{tabular}




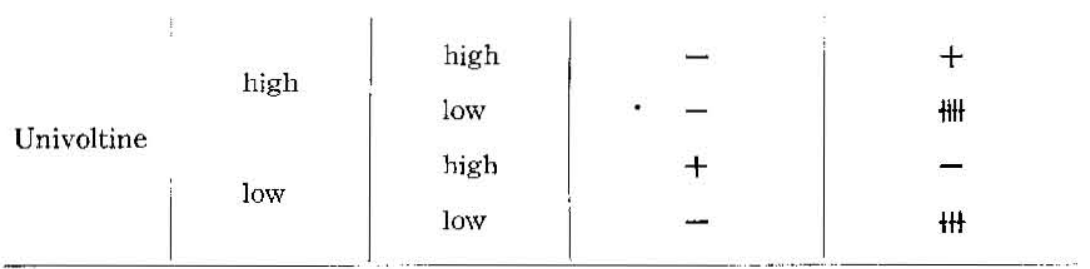

“High" designates $30^{\circ} \mathrm{C}$. in the pupal period and higher than $25^{\circ} \mathrm{C}$. in eggs, while "low" indicates $20^{\circ} \mathrm{C}$. in pupae and lower than $15^{\circ} \mathrm{C}$. for ten days in eggs. Symbol - indicates the smallest, $\mathrm{ll}$ the largest, and the others designate the intermediate rates in succession.

It will be seen that the production of hibernating eggs from the dark-colored is parallel to that for hibernating eggs out of the light-colored, and that both the bivoltine and univoltine differ from the tetravoltine with respect to the way that temperature during the pupal period influences hibernation.

\section{The Bivoltine (including the Univoltine)}

The bivoltine produces more hibernating eggs at high temperature during the pupal period and at low temperature after egg laying than the opposite conditions. Since the hibernation takes place differently according to individual eggs within the same batch and its modification is due to the conditions after pupation, we cannot help assuming that the second hibernation substance is produced at the time of maturation of eggs. As the eggs are liable to become non-hibernating at a certain temperature during two days after laying, the substance might be influenced even in this period.

\section{The Tetravoltine}

The tetravoltine devclops no greater tendency towards hibernation or it has a smaller quantity of the second hibernation substance inherently than the bivoltine. The most susceptible period to the cnvironmental factors for becoming non-hibernating is the pupal period in the tetravoltine, in contrast to the bivoltine in which the period is immediately after egg laying. In other words, the tetravoltine has a longer range of the susceptible period to high temperature which acts to prevent hibernation than the 
bivoltine, that is from the beginning of the pupal period till two days after laying.

The fact that the occurrence of hibernating eggs is variable not only according to individuals within a batch, but also among the different batches, is to be explained likewise in the bivoltine.

\section{Interrelation between the Grades of Egg Color and Hibernation of the Eggs}

The variation of coloration in dark- and light-colored eggs, is contrasted with the proportion of hibernating eggs in the following table.

\section{Table 39}

Comparison of the grades of egg color with the rates of hibernating eggs in the bivoltine (including the univoltine) and the tetravoltine

\begin{tabular}{|c|c|c|c|c|c|c|}
\hline \multirow[b]{2}{*}{ Egg color } & \multirow[b]{2}{*}{$\begin{array}{l}\text { Temperature } \\
\text { during the } \\
\text { pupal period }\end{array}$} & \multirow[b]{2}{*}{$\begin{array}{l}\text { Tempersture } \\
\text { after laying }\end{array}$} & \multicolumn{2}{|c|}{ Bivoltine } & \multicolumn{2}{|c|}{ Tetravoltine } \\
\hline & & & $\begin{array}{l}\text { grades of } \\
\text { erge color }\end{array}$ & $\begin{array}{l}\text { rates of } \\
\text { hibernat- } \\
\text { ing eggs }\end{array}$ & $\begin{array}{l}\text { grades of } \\
\text { egg color }\end{array}$ & $\begin{array}{l}\text { rates of } \\
\text { hibernat- } \\
\text { ing eggs }\end{array}$ \\
\hline \multirow{4}{*}{$\begin{array}{l}\text { Dark- } \\
\text { colored }\end{array}$} & \multirow{2}{*}{ high } & high & + & H & + & - \\
\hline & & low & HH & 㤸 & $\mathrm{HH}$ & tHt \\
\hline & \multirow{2}{*}{ low } & high & $H$ & $H$ & Ht & tt \\
\hline & & low & titit & $H$ & 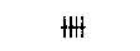 & HH \\
\hline \multirow{4}{*}{$\begin{array}{l}\text { Light- } \\
\text { colored }\end{array}$} & \multirow{2}{*}{ high } & high & + & - & HAt & - \\
\hline & & Iow & $\mathrm{HH}$ & H & HHt & - \\
\hline & \multirow{2}{*}{ low } & high & - & - & H\# & - \\
\hline & & low & $H$ & + & HAt & + \\
\hline
\end{tabular}

At a glance over this table, we know that the dark-colored usually produce more hibernating cggs than the light-colored do. This shows that the first hibernation substance largely accompanies the hibernation of the silkworm eggs.

Examined further, in dark-colored eggs of the tetravoltine, the 
grades of egg color run parallel to hibernation; the more intensive color results in a greater number of hibernating eggs. On the other hand the color grades of the dark-colored of the bivoltine do not always determine the numerical proportion of hibernation; that is, when the pupa is kept at a lower temperature, egg color grows more intensive, while the number of hibernating eggs grows less. This fact may be interpreted by a conception that the changes in the amount of the first and second hibernation substances take place in opposite directions in the pupal period. If the pupa is reared at high temperature, the first hibernation substance decreases catabolicly and lightens egg color, while the second hibernation substance increases and causes the eggs to hibernate.

In light-colored eggs of the bivoltine, the proportion of hibernating eggs is accompanied by an intensity of egg color.

a) After laying, egg color of the light-colored gets more intensive, however at low temperature within the range of $11^{\circ}$ to $30^{\circ} \mathrm{C}$ the number of hibernating eggs tends to increase.

b) Light-colored eggs kcpt under similar environmental conditions usually display some color variations by batches. The eggs of Showa deposited by moths coming from the incubation at $15^{\circ} \mathrm{C}$. in the dark, showed the following variations in the color and hibernating characters.

Table 40

Color variation of light-colored eggs and the number of hibernating eggs
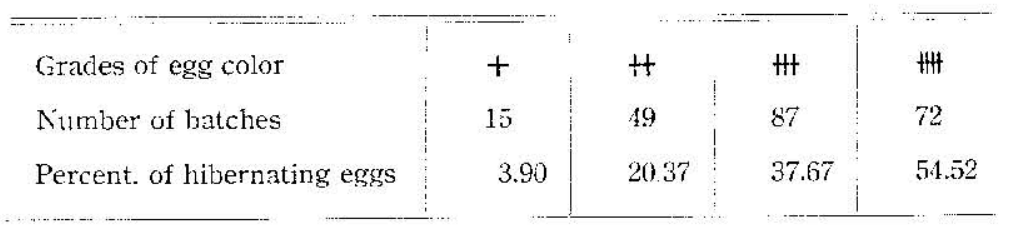

c) When the pupa is kept at high temperature, the color of the light-colored grows more intensive and hibernating eggs more frequent.

d) The color grades of light-colored eggs are different by batches as in the case of dark-colored eggs. In addition to this, 
the color variation can be seen among the individuals in the same batch.

On the ground of the facts above enumerated, I venture to suggest that the second hibernation substance exerts some influence upon the intensity of egg color. At the same time it is conceivable that whatever amount of the second hibernation substance produced in dark-colored eggs may be, the color grades induced by means of the first hibernation substance dominates that of the second substance. Accordingly, the color variation of the dark-colored eggs does not depend upon the amount of the second substance, but upon that of the first substance. On the other hand, the color variation of light-colored eggs depends upon the amount of the second hibernation substance, because the lightcolored have little or no amount of the first substance so that the less intensive coloration by the second substance manifest its proper tone.

Light-colored eggs of the tetravoltine contain a greater quantity of pigment in comparison with those of the bivoltine. As the tetravoltine have little or no amount of the second hibernation substance, their egg color should depend upon other pigment than that contained by the light-colored of the bivoltine. Although it is not yet clear what sort of pigment it is, it is by no means affected by temperature during the pupal period and after egg laying.

\section{Characteristics of the Three Types of Voltinism}

The bivoltine and tetravoltine differ from the univoltine with respect to the production of dark- and light-colorcd cggs. The univoltine is less ready to lay light-colored eggs than the bivoltine and tetravoltine.

As stated previously, the coloring character of the eggs is for the most part controlled by the amount of the first hibernation substance. If the univoltine may possibly be a strongly coloring type, the bivoltine and tetravoltine are a weakly coloring type, because while the former has a large amount of the first hibernation substance, the latter two have a smaller amount.

Although the bivoltine and tetravoltine may have the same tendency for the coloring character, a little discrepancy is re- 
cognized between them; namely that the former gives more easily dark-colored eggs than the latter. Further among different races of the same type of voltinism, there may be found some variability. For example, among the bivoltine races, Shohaku shows a higher percentage of dark-colored eggs than Showa. The small differences may ba due to the variations of hereditary amount of the first hibernation substance.

The bivoltine and univoltine are quite different from the tetravoltine, the former two being likely to turn out non-hibernating, when the pupae were kept at low temperature, and the latter being ready to produce hibernating eggs under the same condition. The former two, as pointed out already, have a great deal of the second hibernation substance and the latter little or none. Among the races of the former type, howevcr, there are some slight differences, presumably hereditary, as is the case between the bivoltine and univoltine.

\section{Summary of Part I}

1. There exist two kinds of silkworm eggs, the dark-colored which bear dark violet pigment within the egg serosa, and the light-colored, which have little or no pigment.

2. The production of moths laying dark-colored and lightcolored eggs depends mostly upon light and temperature during incubation. The response is varied according to the different types of voltinism. The bivoltine and tetravoltine cause nearly all the moths to lay dark-colored eggs when incubated at temperatures above $24^{\circ} \mathrm{C}$. and in the light intensity of $0.5 \mathrm{~F}$. C., while they always produce moths laying light-colored eggs at $15^{\circ} \mathrm{C}$ in the dark. On the other hand, the univoltine never bring forth moths laying light-colored eggs, except that an extremely small number of them results from incubation at $15^{\circ}$ in the dark.

The embryonic period which presents a high degree of susceptibility to light and temperature lies at the time when blood cells differentiatc. If the bivoltine and tetravoltine are subjected to a temperature of $15^{\circ}$ in the dark for fifteen days, only lightcolored eggs result, and if subjected to $20^{\circ} \mathrm{C}$. in the light for five days, a greater number of dark-colored eggs is produced.

3. When eggs of the bivoltine and tetravoltine are incubated 
under intermediate conditions (at $15^{\circ}$ in the light, or $20^{\circ}$ in at the dark), and those of the univoltine are incubated at $15^{\circ}$ in the dark, the effects of light and temperature are still recognized in the following periods.

a) The earlier larval stadia (the first, second and third): If kept at $28^{\circ}$ or $30^{\circ} \mathrm{C}$. and in the light intensity of about $0.5 \mathrm{~F}$. C., the larvae turn out, for the most part, into moths laying darkcolored eggs, and if kept at $20^{\circ}$ in the dark, more moths laying light-colored eggs develop.

b) The later larval instars (the fourth and fifth) and the pupae become more frequently moths laying light-colored eggs under high temperature and light than under low temperature and darkness.

4. The effects of light and temperature during incubation and the earlier larval stadia, upon the production of dark-colored and light-colored eggs are enumerated as follows:- a) If incubation is performed at $20^{\circ} \mathrm{C}$., the light intensity above $0.0095 \mathrm{~F}$. C., or at $15^{\circ} \mathrm{C}$., the light intensity above $0.0136 \mathrm{~F}$. C. favors the production of moths laying dark-colored eggs. The number of light-colored eggs increases as the light intensity decreases within the mentioned intensity limits. During the larval period the lower light intensity limit is about $0.077 \mathrm{~F}$.C. b) Longer wave-lengths of light than $5500 \AA$ have no effect upon the production of darkcolored eggs, likewise in darkness, while shorter wave-lengths than this show a distinct effect upon it, as the white light does. c) Thirteen hours or less exposure to daylight results in a nearly equal number of moths laying light-colored eggs as in continuous darkness. Above fourteen hours, the longer exposure produces the more moths laying dark-colored eggs. During incubation, at a temperature above $20^{\circ}$, more than sixteen hours exposure, and at $15^{\circ}$, more than eighteen hours exposure, and during the larval period, more than eighteen hours exposure result in the same number of moths laying dark-colored eggs as continuous light causes.

5. Though the batch of eggs produced by a silkworm moth is, as a rule, uniform in color, mixed batches, dark- and lightcolored are met with. They occur; a) when the bivoltine and tetravoltine are incubated under intermediate conditions or the univoltine at low temperature and in the dark; b) when the pupa 
is kept at high temperature and in the light, presumably because these conditions affect the final deposits and make them lightcolored.

6. Small color variations occur both in the dark-colored and the light-colored; a) when the pupae are subjected to a high temperature $\left(30^{\circ}\right)$ in the case of the dark-colored, or to a low temperature $\left(20^{\circ}\right)$ in the light-colored, more intensive egg color is produced; b) if the eggs to be dark-colored are kept at $20^{\circ}$ for two or three days after laying or those to be the light-colored are kept at $13^{\circ} \mathrm{C}$. for about ten days after laying, the intensity of egg color becomes exceedingly strong, the farther the divergence from that temperature, the weaker the egg color grows within the range $11^{\circ}$ to $30^{\circ} \mathrm{C}$.

7. Either the dark- or light-colored can be hibernating or non-hibernating eggs. The occurrence of non-hibernating eggs out of the dark-colored and that of hibernating eggs out of the lightcolored does not depend upon light and temperature during incubation, but upon the following conditions: a) In the bivoltine and univol* tine, more hibernating eggs result if the pupa is kept at $30^{\circ} \mathrm{C}$. than at $20^{\circ}$. This is reversed in the tetravoltine. b) When the eggs are subjected to $13^{\circ}$ for fifteen days immediately after laying, more hibernating eggs are produced than when kept at $25^{\circ}$ for two days or at $13^{\circ}$ for more than twenty days. c) In the bivoltine and univoltine, most favorable conditions give about 10 per cent of nonhibernating cggs out of the dark-colored, and more than 50 per cent of hibernating eggs out of the light-colored. It is possible in the tetravoltine to make all the dark-colored eggs non-hibernating, while the light-colored do not hibernate more than an exceedingly small number in any case.

8. Hibernation of the silkworm eggs depends upon two different factors, i.e., the first hibernation substance and the second hibernation substance, as I have designated them:-- a) The first substance is affected most strongly by light and temperature during the incubation period, but slightly in the larval and pupal stages, while the second substance is influenced by temperature only, during the pupal stage and after laying. b) The first substance is uniformly distributed to all eggs laid by the same moth, in contrast to the second substance, which differs in amount not only in different moths but also in different eggs within the same batch. 
9. Fgg color, dark or light, is determined by the amount of the first hibernation substance. The larvae provided with a definite amount of the substance turn into moths laying dark-colored eggs, but under that limit they give light-colored eggs. The embryonic stage and earlier larval stadia are called by the present author an anabolic period for the substance, while the later larval stadia and the pupal stage are designated as a catabolic period.

10. Hibernation of both dark- and light-colored cggs is governed by the amount of the sccond hibernation substance. This substance is increased in amount during the pupal period by means of high temperature. In the case of all races expcrimented with-during the first or days following egg laying - there was manifested a high degree of susceptibility to the environmental stimuli. This was also true in the pupal stage in the tetravolting. In both cases the second substance may be destroyed by high temperature.

11. The first hibernation substance has a great connection with hibernation of eggs in addition two the egg color. The second hibernation substance also controls, besides the hibernation, the egg color variation.

12. Three types of voltinism are distinguishable as regards the amount of the first and second hibernation substances.

$\begin{array}{lcc}\text { Voltinism } & \begin{array}{c}\text { Amount of the first } \\ \text { hibernation substance }\end{array} & \begin{array}{c}\text { Amount of the second } \\ \text { hibernation substance }\end{array} \\ \text { Univoltine } & \text { much } & \text { much } \\ \text { Bivoltine } & \text { scanty } & \text { much } \\ \text { Tetravoltine } & \text { scanty } & \text { scanty }\end{array}$

Some small variations are met with among different races of the same type of voltinism.

\section{PART II \\ INFLUENCE ON THE NUMBER OF IHOLTS \\ Historical Review}

It has already been established that the number of molts of insects is very variable, and that the number of ecdyses may be due to some physical cause.

Lack of food is one of the most effective agents for causing excessive molts. BARNes and GROVE ('16) mentioned that the 
number of molts in Trogoderma granarium, Tribolium castancum, and Lathetics oryzae is dependent on their nutritive conditions. In Tenebrio molitor, different numbers of molts, which might have been caused by different nutritive conditions, were described by HownRD ('96), HeIN ('23) and others. A more convincing instance on this point was noted by TITschacK ('26). According to him, the larva of Tineola biselliella has from four to forty molts, the number varying with the amount of food given. In predaceous insects, also, the number of stages in their larval life seems to be varied by means of changing the kinds of food, as is observed in Sphodromantis bioculata (PRZIBram and Megusar '12), Bättis posticatus (MurPHY '22) and Dytiscus marginalis (BLunck '23).

In the winged insects, especially Lepidoptera, the number of molts is dependent upon the climate. WeNigFr noticed an interesting instance; the larvae of Antheraea mylitta and Ceratocampa imperialis have six stages under normal conditions, but have five stages, i.c., molt four times only when reared in a warmer, moister atomosphere. As to the number of molts of Attacus cecropia, RILLY recorded five and WAILLY six stages. As pointed out by Dimмock ('88), the above mentioned facts may be due to climatic influences. The larva of Callosamia promethea molts but three timcs in warmer climate, as stated by EDwaRDs, it has four times according to LINTNER, who reared it in a northern province of America (Dimmock '88).

PRZIBRAM (in Sphodromantis) and H. H. and C. H. SFverins (13) (in Diapheromera femorata) have stated that temperature plays an important rôle in changing the number of molts; a low temperature decreases and a high temperature increases the number of molts. BARNes and Grove also called attention to the fact that some larvae of Trogoderma reared in the arid season molt but four or five times, while those reared in the rainy season molt five to seven times.

In the silkworm, the larvae molt generally four times. Not a few among them have three or five molts, being designated by the name of a threc- or five-molter. These variations are by no means found simultaneously under the same conditions.

As to the occurrence of the five-molter, some results have been obtained by Niwa ('1i), Kato ('1i), Yokota ('12), KaWASF: and Karasawa ('14), SAKAI ('26), and NAGAMORI ('27). They attributed the cause either to the volcanic ash sprinkled on mulberry 
leaves or to a lower food ration. The appearance of accidental three-molters is more frequent than that of five-molters, nevertheless very little has been known of the exact cause of the occurrence of three-molters. IsHIWATA ('00), IKEDA ('11) and TANAKA ('17) conceived the idea that the larvae bred under warm and moist conditions with good nutrition, tend to be three-molters.

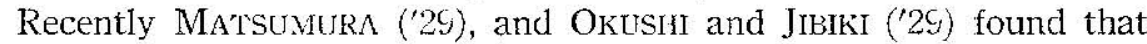
some of the larvae molt only three times when reared at higher temperatures than $28^{\circ} \mathrm{C}$.

I have been concerned in studying the effect of light and temperature on the appearance of three-molters, moisture being kept constant, and have come to the conclusion that light as well as temperature play an important rôle in changing the number of the molts of the silkworm.

\section{Materials and Mcthods}

The races used in these experiments were Showa, Nisshin, Okusa, Chinese No. 105, Chinese No. 4, and Shinano-ohaku, a European race bred in the Nagano-ken Sericultural Experiment Station, and hybrids between some of them. They had not been studied in particular as regards the molting character, but they were all four molting breeds. The eggs of each batch of the same race were divided into a number of approximately equal parts, as in Part I. First count of the three- and four-molters were made at the end of the fourth stadium in the larval life, and the second after pupation. The results obtained in the different races showed fairly good agreement, neglecting a small difference in the rate of three-molters.

The light source was Mazda tungsten 5 and 10 C.P. lamps covered with heat-absorbing glass plates, the distance from them being $1.0 \mathrm{~m}$. in case of incubation and $1.5 \mathrm{~m}$. in case of rearing. The light intensity was controlled as about 0.5 F.C. Rearing trays and ray filters used were the same as used in the preceding cxperiinents. The temperatures were not varied over $0.5^{\circ} \mathrm{C}$. from the desired points throughout the experiments. For the experiments of the incubation period, the larvae were reared at from $30^{\circ}$ to $35^{\circ} \mathrm{C}$., and the eggs for the experiments of the larval period were incubated at $20^{\circ} \mathrm{C}$. as a rule. Since moisture might influence the 
appearance of the three-molter, humidity was always maintained between 80 and 90 per cent during the course of experiments. An effort was made to give an equal quantity and similar quality of food for all lots of the same experiment. The leaves were mostly gathered from two mulberry races, Kairyonezumigaeshi and Kanraso.

\section{Experimental Results}

1. Occurrence of the Threc-molter as influenced by Light and Temperature during the Incubation Period

\section{A. Effects of Light}

a) Light and darkness As a preliminary to more extensive experiments numerous trials were made of light and darkness. The experiment was done on six different occasions, with fairly constant results which are shown in Table 41. More than 13 per cent of three-molters were obtained in the dark, that is twice as many as resulted in the light.

\section{Table 41}

Effects of light and darkness upon the occurrence of the three-molter during the incubation period

\begin{tabular}{c|c|c|c|}
\hline Light conditions & $\begin{array}{c}\text { Number of the } \\
\text { three-molter }\end{array}$ & $\begin{array}{c}\text { Number of the } \\
\text { four-molter }\end{array}$ & $\begin{array}{c}\text { Percent. of the } \\
\text { three-molter }\end{array}$ \\
\hline light & 220 & 4013 & 5.20 \\
dark & 566 & 3567 & 13.69 \\
\hline
\end{tabular}

b) Length of day Since, in the foregoing experiment, light appeared to be unfavorable to the occurrence of the three-molter, other trials were carried out to detect whether the relative length of day would have any connection with their appearance. The eggs, after being divided into five parts, were incubated. These parts werc alloted to lots having the alternation of 18 hours of light and 6 hours of darkness, 12 hours of light and 12 hours of darkness, 6 hours of light and 18 hours of darkness, and two lots of continuous light and continuous darkness. The same experiments undertaken twice showed results in agreement. 
Table 42

Effects of the length of day upon the occurrence of the three-molter during the incubation period

\begin{tabular}{l|c|c|c}
\multicolumn{1}{c}{ Length of day } & $\begin{array}{c}\text { Number of the } \\
\text { three-molter }\end{array}$ & $\begin{array}{c}\text { Number of the } \\
\text { four-molter }\end{array}$ & $\begin{array}{c}\text { Percent. of the } \\
\text { three-molter }\end{array}$ \\
\hline continuous darkness & 238 & 1305 & 15.42 \\
6 hours light & 215 & 1275 & 14.43 \\
12 hours light & 220 & 1397 & 13.61 \\
18 hours light & 115 & 1176 & 8.91 \\
continuous light & 97 & 1072 & 8.30 \\
\hline
\end{tabular}

About twice as many three-molters were produced under either continuous darkness or less than 12 hours exposure to light as under either continuous light or 18 hours light.

Another detailed experiment, to asceitain photoperiodism in the occurrence of the three-molter, was carried out in six lots. Four alloted to increased daily exposure to light by three hours from 12 up to 21 hours, and the remaining two to the controls, continuous light and continuous darkness. The rcsults will be seen in the following table.

\section{Table 43}

Effects of more than 12 hours daily exposure to light upon the rate of occurrence of the three-molter during the incubation period

\begin{tabular}{|c|c|c|c|}
\hline Length of day & $\begin{array}{l}\text { Number of the } \\
\text { three-molter }\end{array}$ & $\begin{array}{l}\text { Number of the } \\
\text { four-molter }\end{array}$ & $\begin{array}{l}\text { Percent. of the } \\
\text { three-molter }\end{array}$ \\
\hline continuous darkness & 34 & 746 & 4.36 \\
\hline 12 hours light & 44 & 812 & 5.14 \\
\hline 15 hours light & 3 & 723 & 0.41 \\
\hline 18 hours light & 0 & 725 & 0 \\
\hline 21 hours light & 1 & 771 & 0.13 \\
\hline contiuuous light & 1 & 640 & 0.16 \\
\hline
\end{tabular}


The table shows that more than 15 hours gave exceedingly small numbers of three-molters, while continuous darkness and 12 hours light favored their occurrence.

c) Wave-lengths of light The eggs, after being parcelled out into five lots, were incubated in different boxes with various ray filters. The boxes were arranged to relatively equalize the total radiation energy through various glass plates, and were kept at different distances, as mentioned in the studies on hibernation. Four sets of similar experiments may be summarized as follows.

Three-molters were produced most abundantly in the red, orange-yellow and dark, while very scantily in the violet and white, as may be seen from Table 44. In other words, larger wavelengths of light than $5500 \AA$, which the orange-yellow glass plate permits, act similarly to darkness, while those below that limitation inhibit the appearance of the three-molter.

\section{Table 4.4}

Effects of light rays of different filters upon the occurrence of the three-molter during the incubation period

\begin{tabular}{l|c|c|c}
\hline Ray filters & $\begin{array}{c}\text { Number of the } \\
\text { three-molter }\end{array}$ & $\begin{array}{c}\text { Number of the } \\
\text { four-molter }\end{array}$ & $\begin{array}{c}\text { Percent. of the } \\
\text { three-1nolter }\end{array}$ \\
\cline { 1 - 3 } dark & 222 & 3692 & 5.67 \\
red &, 154 & 3263 & 4.51 \\
vrange-yellow & 197 & 3434 & 5.43 \\
violet & 85 & 3555 & 2.33 \\
white & 48 & 3688 & 1.28 \\
\hline
\end{tabular}

d) Period of the cmbryo to be affected by light The eggs, after passing into the next year of oviposition, were parcelled out into five lots. The incubation of all the lots was begun at once in the dark, at a constant temperature of $20^{\circ} \mathrm{C}$. The first lot was brought to the light on the first day, the second on the fourth day, the third on the eighth day, the fourth on the twelfth day and the last was drawn out on the sixteenth day, when most of the eggs had hatched out. The stages of the embryonic development were examined from outside or taking off the egg-shell. 
The lots brought into the light on the first and fourth days, before the blastokinesis of the embryo, were able to produce less numbers of three-molters than the others undergoing less exposure, as shown in Table 45.

\section{Table 45}

Results of the experiment in which the lots were moved from darkness into light at different stages of the embryo

\begin{tabular}{c|c|c|c|c}
\hline $\begin{array}{c}\text { Date on which } \\
\text { lots were brought } \\
\text { to the light }\end{array}$ & $\begin{array}{c}\text { Number of } \\
\text { days in the } \\
\text { light }\end{array}$ & $\begin{array}{c}\text { Nnmber of } \\
\text { the } \\
\text { three-molter }\end{array}$ & $\begin{array}{c}\text { Number of } \\
\text { the } \\
\text { four-molter }\end{array}$ & $\begin{array}{c}\text { Percent. of } \\
\text { the } \\
\text { three-molter }\end{array}$ \\
\hline 1st & 16 & 3 & 298 & 1.00 \\
4th & 12 & 1 & 412 & 0.24 \\
8th & 8 & 19 & 529 & 3.47 \\
12th & 4 & 28 & 521 & 5.10 \\
16 th & 0 & 27 & 449 & 5.67 \\
\hline
\end{tabular}

The embryo hatches out in a day or two after the embryonic body is completed. During this period the eggs may be refrigerated at a low temperature of less than $10^{\circ} \mathrm{C}$. in order to suppress hatching, as commonly performed by sericulturists. I separated the eggs into two parts, one of which was exposed to light and the other kept dark, both being left for ten days at $7^{\circ} \mathrm{C}$. The results obtained from four trials, show that the lots exposed to light produced 19.65 per cent of three-molters in the mean, while the darkened resulted in 12.81 per cent.

From the facts above described, we assume that light acts in the period subsequent to the completion of the embryo, contrary to its effect during the proceding period of incubation.

\section{B. Effects of Temperature}

a) Incubation temperature Four degrees of temperature, $30^{\circ}$, $25^{\circ}, 20^{\circ}$ and $15^{\circ} \mathrm{C}$. were used. The eggs in the hibernating state, were divided into four lots and were refrigerated at $0^{\circ} \mathrm{C}$. To cause the eggs to hatch out on the same day, the eggs which were to be 
incubated at the lower temperatures, were taken out carlier from the refrigerator. The light was the same under different temperatures, but no attempt was made to keep it constant. The trials were carried out four times.

\section{Table 46}

Effects of different temperatures upon the occurrence of the three-molter during the incubation period

\begin{tabular}{c|c|c|c}
\hline $\begin{array}{c}\text { Incubation temp. } \\
\text { in C. }\end{array}$ & $\begin{array}{c}\text { Number of the } \\
\text { three-molter }\end{array}$ & $\begin{array}{c}\text { Number of the } \\
\text { four-molter }\end{array}$ & $\begin{array}{c}\text { Percent. of the } \\
\text { three-molter }\end{array}$ \\
\hline 30 & 24 & 2083 & 1.14 \\
25 & 49 & 2567 & 1.87 \\
20 & 294 & 2035 & 12.62 \\
15 & 80 & 2006 & 3.84 \\
\hline
\end{tabular}

At $20^{\circ}$, more than 12 per cent turned into threc-molters, and at $15^{\circ}$, about 4 per cent resulted. At the temperatures above $25^{\circ}$, the number of three-molters decreased exceedingly.

b) Period of the embryo to be affected by temperature To. know what stages of the embryo are more affected by temperature, the experiment was performed thrice in removing eggs from a temperature of $25^{\circ}$ into that of $15^{\circ} \mathrm{C}$. at different stages of the embryo. Among five experimental lots, the first was alloted to the control which was placed at $15^{\circ}$ from the beginning of incubation, the second was removed from $25^{\circ}$ into $15^{\circ}$ on the third day, the third on the sixth day, the fourth on the ninth day, and the last was kept at $25^{\circ}$ throughout the incubation period. These lots were treated to make: the eggs hatch out on the same day, and the experiment was carried out under the condition of darkness. The results obtained will be seen in the following table.

\section{Table 47}

Results of the experiment in which each lot was removed from $25^{\circ}$ into $15^{\circ} \mathrm{C}$. 


\begin{tabular}{c|c|c|c|c}
\hline $\begin{array}{c}\text { Date on which } \\
\text { lots were } \\
\text { moved into 15 }\end{array}$ & $\begin{array}{c}\text { Number of } \\
\text { days at } \\
15^{\circ}\end{array}$ & $\begin{array}{c}\text { Number of } \\
\text { the } \\
\text { three-molter }\end{array}$ & $\begin{array}{c}\text { Number of } \\
\text { the } \\
\text { four-molter }\end{array}$ & $\begin{array}{c}\text { Percent. of } \\
\text { the } \\
\text { three-molter }\end{array}$ \\
\hline 1st & 30 & 8 & 1836 & 0.43 \\
$3 \mathrm{rd}$ & 22 & 15 & 1383 & 1.07 \\
6 th & 16 & 42 & 1809 & 2.27 \\
9th & 5 & 38 & 1716 & 2.17 \\
11th & 0 & 26 & 2035 & 1.26 \\
\hline
\end{tabular}

The lots which were moved on the sixth and ninth days resulted in higher percentages of three-molters, while in other lots they were very scanty. Namely, the low temperature of $15^{\circ}$ from the beginning of incubation, as well as the high temperature of $23^{\circ}$ throughout the timc of incubation, exerted little effect upon the appearance of the three-molter.

In this experiment, the state of the cmbryo on the sixth day was that of blastokinesis. It may be said, therefore, that the high temperature before the blastokinesis as well as the low temperature after that stage are both favorable for the production of three-molters.

According to the data above given, it is possible to recognize three developmental stages responding differently to light and temperature. The first stage ranges from the beginning up to the blastokinesis in which high temperature conduces to the production of the three-molter; the third stage succeeding to the completion of the embryo is favored by light for producing it; the second stage intervening the above two is negatively affected by light and temperature.

\section{Concurrent and Antagonistic Action of Light and Temperature during the Incubation Period}

Four different temperatures, $30^{\circ}, 25^{\circ}, 20^{\circ}$ and $15^{\circ} \mathrm{C}$., were used. The eggs were divided into two lots for each temperature, one kept light, the other dark. The results of the two extensive tests are represented, in the aggregate, in Table 48. 
Table 48

Effects of light and temperature combined during the incubation period upon the occurrence of the three-molter

\begin{tabular}{|c|c|c|c|c|}
\hline $\begin{array}{r}\text { Conditiol } \\
\text { temp. in C. }\end{array}$ & $\begin{array}{l}\text { is of incubation } \\
\text { light conditions }\end{array}$ & $\begin{array}{l}\text { Number of the } \\
\text { three-molter }\end{array}$ & $\begin{array}{l}\text { Number of the } \\
\text { four-molter }\end{array}$ & $\begin{array}{l}\text { Pcrcent. of the } \\
\text { three-molter }\end{array}$ \\
\hline 30 & $\begin{array}{l}\text { light } \\
\text { dark }\end{array}$ & $\begin{array}{l}13 \\
11\end{array}$ & $\begin{array}{l}1018 \\
1065\end{array}$ & $\begin{array}{l}1.26 \\
1.02\end{array}$ \\
\hline 25 & $\begin{array}{l}\text { light } \\
\text { dark }\end{array}$ & $\begin{array}{l}21 \\
28\end{array}$ & $\begin{array}{l}1261 \\
1306\end{array}$ & $\begin{array}{l}1 . € 4 \\
2.10\end{array}$ \\
\hline 20 & $\begin{array}{l}\text { light } \\
\text { datrk }\end{array}$ & $\begin{array}{r}93 \\
204\end{array}$ & $\begin{array}{r}1146 \\
889\end{array}$ & $\begin{array}{r}7.28 \\
18.66\end{array}$ \\
\hline 15 & $\begin{array}{l}\text { light } \\
\text { dark }\end{array}$ & $\begin{array}{l}22 \\
58\end{array}$ & $\begin{array}{r}938 \\
1068\end{array}$ & $\begin{array}{l}2.29 \\
5.15\end{array}$ \\
\hline
\end{tabular}

The difference between light and darkness was negligible at $30^{\circ}$, while it was considerable at the other three temperatures, es-

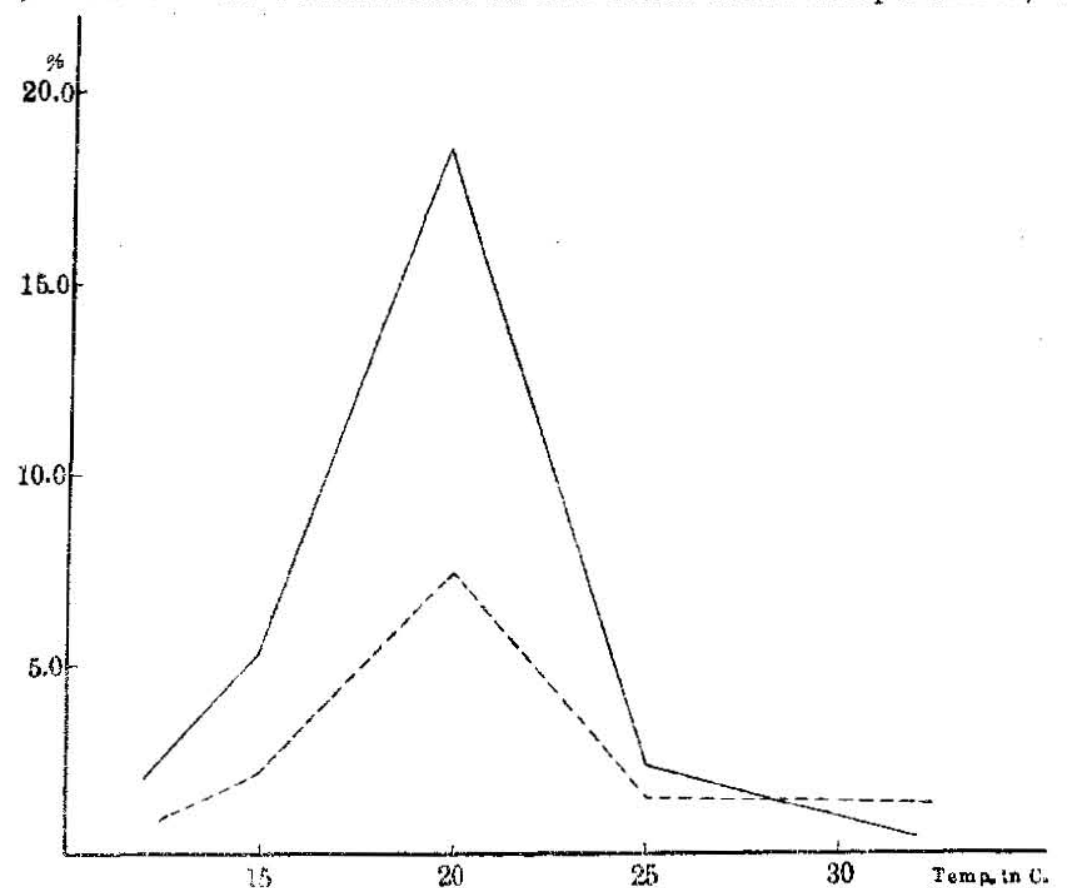

Fig. 1. Variation of three-molter percentages in case of incubation. The broken line represents values obtained in the light; the solid line, those in the dark. 
pecially at $20^{\circ}$. With respect to temperature, $20^{\circ}$ showed highest percentages, $15^{\circ}$ gave more three-molters than those of $25^{\circ}$ and $30^{\circ}$ (Fig. 1).

2. Occurrence of the Three-molter as influenced by Light and Temperature during the Larval Period

\section{A. Effects of Light}

a) Light and darkness The first and second instars of one series of lots were reared in the light, and those of the other series in the dark. In the first group, the different lots were reared at different temperatures above $30^{\circ} \mathrm{C}$. They gave, in average, 12.56 per cent of three-molters in the light and 2.43 per cent in the dark. In these cases light acted positively for producing three-molters.

In the second group, the different lots were reared at different temperatures, below $28^{\circ} \mathrm{C}$. They resulted in 0.36 per cent of three-molters in the light, and 1.06 per cent in the dark. Here darkness was more favorable for the production of the threemolter than light, though the difference was very small.

b) Length of day Relative length of daily exposure to light also may result in different ways according to the temperature under which the earlier larval stadia were kept. At a temperature above $30^{\circ} \mathrm{C}$, the larvae in the first and second stadia were parcelled out into nine lots, the first of which was kept in continuous darkness, the second in alternating 3 hours light and 21 hours darkness, the other lots increasing light exposure daily by 3 hours successively, and the last was kept in continuous light. The experiment was performed nine times with the results given in Table 49.

As is to be seen from this table, there is no definite photoperiodism for the appearance of the three-molter. Below 12 hours lighte xposure, very small numbers of three-molters occurred. An exposure of 15 hours or it showed a larger number increasing with the daily exposure, and attaining the maximum in continuous light.

The second test was carried out in the same manner, except that the first and second instars were reared below $28^{\circ} \mathrm{C}$. (Table 50 ). 
Table 49

Effects of the length of day upon the occurrence of the three-molter, when the earlier larval stadia were reared above $30^{\circ} \mathrm{C}$.

\begin{tabular}{l|c|c|c}
\hline \multicolumn{1}{|c|}{ Length of day } & $\begin{array}{c}\text { Number of the } \\
\text { three-molter }\end{array}$ & $\begin{array}{c}\text { Number of the } \\
\text { four-molter }\end{array}$ & $\begin{array}{c}\text { Percent. of the } \\
\text { three-moiter }\end{array}$ \\
\hline continuous darkness & 47 & 8935 & 0.52 \\
3 hours light & 47 & 8419 & 0.56 \\
6 hours light & 70 & 9035 & 0.77 \\
9 hours light & 69 & 8897 & 0.77 \\
12 hours light & 105 & 9381 & 1.11 \\
15 hours light & 172 & 9156 & 1.84 \\
18 hours light & 217 & 8685 & 2.44 \\
21 hours light & 467 & 7611 & 5.78 \\
continuous light & 623 & 8046 & 7.19 \\
\hline
\end{tabular}

Table 50

Effects of the length of day upon the occurrence of the threemolter, when the earlier larval stadia were kept below $28^{\circ} \mathrm{C}$.

\begin{tabular}{l|c|c|c}
\hline \multicolumn{1}{c|}{ Length of day } & $\begin{array}{c}\text { Number of the } \\
\text { three-molter }\end{array}$ & $\begin{array}{c}\text { Number of the } \\
\text { four-molter }\end{array}$ & $\begin{array}{c}\text { Percent. of the } \\
\text { three-molter }\end{array}$ \\
\hline continuous darkness & 3 & 872 & 0.34 \\
3 hours ligut & 5 & 900 & 0.55 \\
6 hours light & 3 & 793 & 0.38 \\
9 hours light & 4 & 800 & 0.50 \\
12 hours light & 1 & 822 & 0.12 \\
15 hours light & 0 & 799 & 0 \\
18 hours light & 0 & 812 & 0 \\
21 hours light & 0 & 883 & 0 \\
continuous light & 0 & 896 & 0 \\
\hline
\end{tabular}


A few three-molters appeared in less than 13 hours light exposure, but none in more than 15 hours exposure.

In the third experiment, different races were reared in different seasons of the year than the proceeding trials. The first arrd second instars were reared below $28^{\circ} \mathrm{C}$. and then separated into nine lots, one of which was kept in continuous darkness, seven in more than 12 hours light exposure increasing hour by hour up to 19 hours, and the rest in continuous light. The experiment was performed on two different occasions, with results which are tabulated below.

\section{Table $5 \mathfrak{I}$}

Effects of the length of day during the carlier larval stadia upon the occurrence of the three-molter, in the case of more than 12 hours exposure, the temperature being kept below $28^{\circ} \mathrm{C}$.

\begin{tabular}{|c|c|c|c|}
\hline Length of day & $\begin{array}{l}\text { Number of the } \\
\text { three-molter }\end{array}$ & $\begin{array}{l}\text { Number of the } \\
\text { four-molter }\end{array}$ & $\begin{array}{l}\text { Percent. of the } \\
\text { three-molter }\end{array}$ \\
\hline continuous darkness & 19 & 1178 & 1.59 \\
\hline 12 hours light & 60 & 1121 & 5.08 \\
\hline 13 hours light & 32 & 1079 & 2.88 \\
\hline 14 hours light & 18 & 1182 & 1.50 \\
\hline 15 hours light & 9 & 1050 & 0.85 \\
\hline 16 hours light & $i$ & 1227 & 0.57 \\
\hline 17 hours light & 9 & 1251 & 0.71 \\
\hline 18 hours light & 9 & 1200 & 0.74 \\
\hline 19 hours light & 15 & 1208 & 1.23 \\
\hline continuous light & 6 & 1195 & 0.50 \\
\hline
\end{tabular}

The very great excess of the three-molter was recognized in less than 13 hours light over that of more than 15 hours light. Below $28^{\circ}$, the photoperiodism is distinct, namely the limit of daily exposure at which an equal or more numbers of the three-moiter to be obtained as in continuous darkness, rests at 12 or 13 hours exposure to light. 
c) Wave-lengths of light The first and second instars were divided into five lots, the first lot of which was kept dark, the second in red rays, the third in orange-yellow, the fourth in violet, and the fifth in white. The temperature was the same in the five lots. (Table 52.)

The results obtained on ten different occasions were quite different according to temperatures, high (above $30^{\circ} \mathrm{C}$.) and low (below $23^{\circ} \mathrm{C}$.). At the temperature above $30^{\circ}$, larger numbers of larvae reared in the violet and white rays underwent three molts in the larval life, while very few did so under the rod, orange-yellow and darkened conditions. On the other hand, at the temperature below $28^{\circ}$ no three-molter was found in the violet and white rays, and a few appeared in the red, in the orange-yellow as well as in the dark. In short the rays longer than $5500 \AA$ A which is transmissible by the orange-yellow plate, seem to favor the production of the threcmolter below $28^{\circ}$, while the rays of shorter wave-lengths conduce to it above $30^{\circ}$.

\section{Table 52}

Effects of light rays of different filters upon the occurrence of the three-molter during the earlier larval stadia

\begin{tabular}{|c|c|c|c|c|}
\hline $\begin{array}{l}\text { Rearing } \\
\text { temp in } \mathrm{C} .\end{array}$ & Ray filters & $\begin{array}{l}\text { Number of the } \\
\text { three-molter }\end{array}$ & $\begin{array}{l}\text { Number of the } \\
\text { four-molter }\end{array}$ & $\begin{array}{l}\text { Percent. of the } \\
\text { three-molter }\end{array}$ \\
\hline \multirow{5}{*}{ Above $30^{\circ}$} & dark & 67 & 2566 & 2.54 \\
\hline & red & 146 & 2727 & 5.08 \\
\hline & orange-yellow & 143 & 2568 & 5.27 \\
\hline & violet & 391 & 2357 & 14.23 \\
\hline & white & 368 & 2588 & 12.45 \\
\hline \multirow{5}{*}{ Below $28^{\circ}$} & dark & 1 & 564 & 0.18 \\
\hline & red & 2 & 638 & 0.31 \\
\hline & orange-yellow & 1 & $€ 47$ & 0.15 \\
\hline & violet & 0 & 504 & 0 \\
\hline & white & 0 & 501 & 0 \\
\hline
\end{tabular}


d) Changes of light conditions and the larval stadia. The rates of the appearance of the three-molter secm to vary with different larval stadia. At $30^{\circ} \mathrm{C}$., six lots of larvac were subjected to light during different stadia. The other larval stadia than those subjected to light, were reared under a dark condition.

\section{Table 53}

Results of the experiment to determine the effect of light and the larval stadia upon the occurrence of the three-molter

\begin{tabular}{l|c|cc}
\hline Stadia exposed to light & $\begin{array}{c}\text { Number of the } \\
\text { three-molter }\end{array}$ & $\begin{array}{c}\text { Number of the } \\
\text { four-molter }\end{array}$ & $\begin{array}{c}\text { Percent. of the } \\
\text { three-molter }\end{array}$ \\
\hline stadium 1 light & 19 & 892 & 2.31 \\
stadium 2 light & 23 & 812 & 2.75 \\
stadium 3 light & 11 & 820 & 1.32 \\
stadia 1+2 light & 42 & 695 & 5.70 \\
stadia 2+3 light & 33 & 776 & 4.08 \\
stacia 1 & 72 & 615 & 10.48 \\
\hline
\end{tabular}

Light exerted a greater effect in the first and second stadia than in the third. If subjected to light for any two successive stadia, the effect was more prominent than for any one stadium. The lots kept light from the first to third stadia displayed the highest percentages of the three-molter.

Another experiment showed that no three-molter appcarcd when the fourth stadium was kept light and the other stadia were reared in darkness.

\section{B. Effects of Temperature}

a) Different temperatures Since, lower temperatures than $28^{\circ} \mathrm{C}$, in the foregoing experiments, appeared to be unfavorable to the production of the three-molter, while higher temperatures than $30^{\circ}$ resulted in higher percentages of it, four different temperatures, $35^{\circ}, 30^{\circ}, 25^{\circ}$ and $20^{\circ} \mathrm{C}$, were used, for the first and second instars in this experiment. The trials were made on four different occasions, and light conditions were uniform in any one experiment, but different from one to another. The results showed 
in average, 5.90 per cent of the three-molter at $35^{\circ}, 4.50$ per cent at $30^{\circ}$, but none at all below $25^{\circ}$.

b) High temperature and the larval stadia The larvae in the earlier larval stadia were divided into four lots, each of which was reared at $35^{\circ} \mathrm{C}$. during one of the different stadia, the other stadia than those subjected to the high temperature being kept at $25^{\circ} \mathrm{C}$. The similar experiments were carried out twice in the light.

Table 54

Results of the experiment to determine the effect of high temperature and the larval stadia up on the occurrence of the three-molter

\begin{tabular}{c|c|c|c}
\hline $\begin{array}{c}\text { Stadia kept at } \\
\text { ligh temp. }\end{array}$ & $\begin{array}{c}\text { Number of the } \\
\text { three-molter }\end{array}$ & $\begin{array}{c}\text { Number of the } \\
\text { four-molter }\end{array}$ & $\begin{array}{c}\text { Percent. of the } \\
\text { three-molter }\end{array}$ \\
\hline studium 1 high & 82 & 1251 & 6.15 \\
stadium 2 high & 71 & 1327 & 5.08 \\
stadium 3 high & 14 & 1122 & 1.23 \\
stadium 4 high & 0 & 1084 & 0 \\
\hline
\end{tabular}

The results are in agreement with those obtained from the experiment made in connection with light; the effect of temperature in the first and second instars was clearly seen, but it was slight in the third and there was none in the fourth instars.

\section{Concurrent and Antagonistic Action of Light and Temperature during the Larval Period}

Four lots of larvae in the earlier larval stadia from the first to third, were placed at temperatures of $35^{\circ}, 31^{\circ}, 27^{\circ}$ and $23^{\circ} \mathrm{C}$., respectively. For each temperature the larvae were divided into two lots, one kept in the light, the other in the dark. The results are recorded in Table 55. No three-molter was found at $23^{\circ} \mathrm{C}$, but the higher the temperature, the more three-molters resulted. Quite in harmony with the facts described in the previous sections, darkness favored the appearance of the three-molter, at $27^{\circ} \mathrm{C}$, while light was much more conducive to their production at the higher temperatures. 


\section{Table 55}

Effects of light and temperature combined during the larval period upon the occurrence of the thrce-molter

\begin{tabular}{|c|c|c|c|c|}
\hline \multicolumn{2}{|c|}{$\begin{array}{c}\text { Conditions of rearing the } \\
\text { earlier instars }\end{array}$} & \multirow{2}{*}{$\begin{array}{l}\text { Number of the } \\
\text { three-molter }\end{array}$} & \multirow{2}{*}{$\begin{array}{l}\text { Number of the } \\
\text { four-molter }\end{array}$} & \multirow{2}{*}{$\begin{array}{l}\text { Percent. of the } \\
\text { three-molter }\end{array}$} \\
\hline temp. in C. & light conditions & & & \\
\hline 35 & $\begin{array}{l}\text { light } \\
\text { dark }\end{array}$ & $\begin{array}{r}115 \\
39\end{array}$ & $\begin{array}{l}1323 \\
1158\end{array}$ & $\begin{array}{l}8.00 \\
3.26\end{array}$ \\
\hline 31 & $\begin{array}{l}\text { light } \\
\text { dark }\end{array}$ & 17 & $\begin{array}{l}1298 \\
1564\end{array}$ & $\begin{array}{l}1.29 \\
0.45\end{array}$ \\
\hline 27 & $\begin{array}{l}\text { light } \\
\text { dark }\end{array}$ & $\frac{1}{3}$ & $\begin{array}{l}1197 \\
1427\end{array}$ & 0.08 \\
\hline 23 & $\begin{array}{l}\text { light } \\
\text { dark }\end{array}$ & $\begin{array}{l}0 \\
0\end{array}$ & $\begin{array}{l}1447 \\
1290\end{array}$ & $\begin{array}{l}0 \\
0\end{array}$ \\
\hline
\end{tabular}

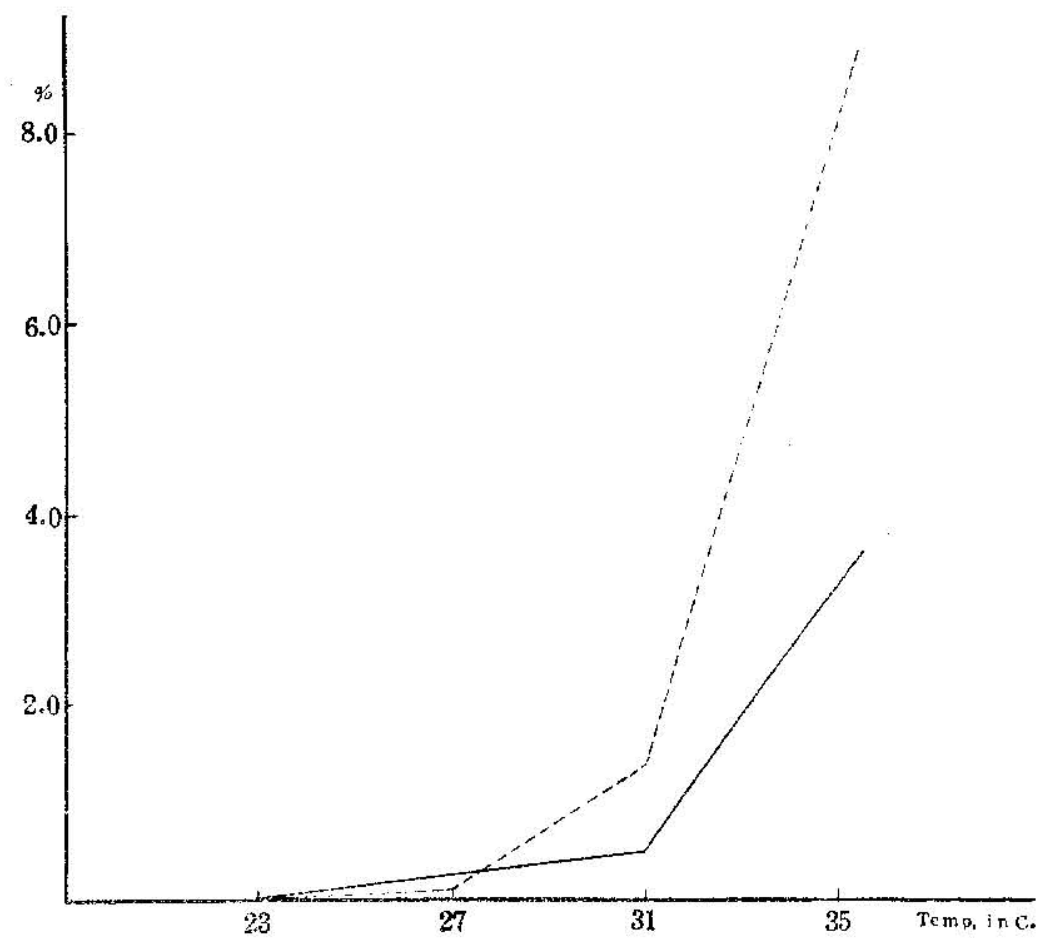

Fig. 2. The effects of light and temperature during the larval life on the percentages of the three-molter. The broken line represents values obtained in the light; the solid line, those in the dark. 
If the results obtained in the light and those in the dark are analyzed, it may be seen that the proportion of the three-molter is dependent on temperature, and it advances by lcaps under light as compared with that in darkness (Fig. 2).

\section{Sex-ratio of the Three-molter}

The interrelation between the number of molts and the sexratio was discussed by such authors as KLATT ('08), Rilfy, HENLIin (Dimmock ;88), Barnes and Grove ('i6), and Titschack (26). They noticed a sexual difference as regards the number of molts in certain species of insects, the female under going more molts than the male. In the silkworm, SAKAI ('26), among others, observed most extensively the sex of five-molters caused by the volcanic ash, and noted that the percentage of males was very variable with a mean of 46.06 per cent.

I scrutinized the sex of 646 three-molters and found them consisting of 516 males and 130 females, i.e., 79.88 per cent of males. The four-molters from which the three-molters in question came, gave a sex-ratio of 45.15 per cent of males among 3859 larvae. The four-molters and three-molters being considered as a whole, the sex-ratio was 50.34 per cent, the actual number of males being 2268 , and that of females 2237 . It is evident, therefore, that the male has a tendency to be the three-molter.

\section{Racial Difference of Rates of the Appearance of the Three-molter}

The rates of the appearance of the three-molter were very variable in the above mentioned experiments. This is perhaps due to the fact that the races used were not inbred with regard to the genetical constitution for the three-molting character.

It scems that the three-molters occur a little oftener in Chinese races than in Japanese and European races. The $F_{1}$ hybrids between different Chinese races and those between a Chinese and a Japanese or European usually give rise to more three-molters than the parental races do. 


\section{On the Cause of the Molting}

It has been believed that the ecdysis of insects has relation to their growth. PRziBram ('12) advocated that in Sphodromantis the doubling of the body weight induced molting, and later, in Carausins morosus, a similar idea was advocated by TiтsсHACK ('24) and EidMANN ('24). Later Titschack ('26) observed cases of ecdyses of the larva in Tineola biselliela without any growth. EIDMANN also denied any definite connection between growth and molting, ascertaining that the inner pressure of the body has no relation to the ecdysis.

TITSCHACK is of the opinion that the ecdysis of insects should be regarded as the process of anagenesis, serving as physical countcraction; the greater the amount the more often the larva molts. This is why that the molting is more frequent in the female than in the male. He ascertained that the intervals between molts are unusually extended in case of bad nutrition, by virtue of the prolongation of counteraction. TITSCHACK's hypothesis is, it seems to me, insufficient to fully explain the fact that the number of molts is increased and the larval life is prolonged with the lowering of nutrition, notwithstanding the decrease of the total amount of anagenesis in this case.

The respiratory quotient of the silkworm is calculated by KAWASE ('14) as 0.7 or thereabouts, throughout the entire life history. If carbohydrates are chiefly burned, as stated by HiRATSUKA ('20) during the larval period, the quotient ought to show a much higher value. The unusually lowered quotient seems to suggest the formation of certain oxides other than carbon dioxide within the body. The molting fluid contains a large amount of oxalates as well as proteins (PlotNIKow '04, Schllze '12). As the oxalates are oxides, that is, the end products in the metabolic process, it may be said that the definite quantitative accumulation of the oxalic salts irritates the larva and causes molting.

Although NAGAMORI insists that dryness causes an excessive number of molts, I am inclined to attribute his results to lowered nutrition due to the withering of mulberry leaves. According to KAWASE, by starvation the larva losses its body weight gradually, and the carbon dioxide output and 'oxygen consumption drop in a large measure with the result that the respiratory quotient decreases. 


\section{Table 56}

Respiratory quotient of the larva in the fourth stadium in starvation

\begin{tabular}{c|c|c|c|c|c}
\hline $\begin{array}{c}\text { Time of star- } \\
\text { vation in hours }\end{array}$ & $\begin{array}{c}\text { Number of } \\
\text { larvae }\end{array}$ & $\begin{array}{c}\text { Body weight } \\
\text { in gr. }\end{array}$ & $\begin{array}{c}\mathrm{O}_{2} \text { consumed } \\
\text { in } \mathrm{cm} .\end{array}$ & $\begin{array}{c}\mathrm{CO}_{2} \text { output } \\
\text { in } \mathrm{cm} .\end{array}$ & $\begin{array}{c}\text { Respiratory } \\
\text { quotient }\end{array}$ \\
\hline 15 & 100 & 22.47 & 42.35 & 30.56 & 0.722 \\
30 & 100 & 22.23 & 32.70 & 19.44 & 0.594 \\
63 & 100 & 21.17 & 25.77 & 14.83 & 0.575 \\
\hline
\end{tabular}

The decrease of the respiratory quotient by starvation is due to the great quantity of oxygen remaining free. The excess oxygen should induce an abnormal accumulation of oxides, which may have some connection with the appearance of the five-molter.

SAKAI believes the third stadium most conducive to the pro. duction of five-molters in lack of food. NAGAMORI insists that the first stadium is most influential on this, becoming less and less as the stadium advances up to the end of the third. However different the opinion of the two investigators may be, they agree in this that it is prior to the third stadium of the larva that lack of food increases the number of molts.

In the respiratory quotient little difference is found in the earlier and later instars. According to HrRATsuka, less quantity of fat is reserved in the earlier stadia than in the later instars. From this point of view, the respiratory quotient should be higher in the former than in the latter. The actual depression of the quotient in the earlier instars must induce a condition similar to the case of starvation. Thus some oxides other than carbon dioxide are produced in excess during this period, which gives rise to an excessive number of molts.

In regards to the occurrence of three-molters out of the fourmolting strain, climatic influences, especially light and temperature, are most effective agents, putting aside the nutritive conditions for a moment. The first and second stadia show the highest sensibility to light and temperature upon producing the three-molter. During that period, at temperatures higher than $30^{\circ} \mathrm{C}$. light favors the appearance of the three-molter. At temperatures below $28^{\circ} \mathrm{C}$., 
however, light gives a little less three-molters than darkness. This phenomenon is difficult to explain at present.

The reduction in the number of molts is partially due to the influence of light and temperature during egg incubation. If darkness and the temperature of $20^{\circ}$ or $15^{\circ} \mathrm{C}$. are kept throughout the period from the blastokinesis to the completion of the embryo, a larger number of the three-molting larvae results than in the light and higher temperatures. TITSCHACK stated that temperature has nothing to do with varying the number of molts of Tineola, and that this may be amplified to some insects, for instance, Sphodromantis, Trogoderma, etc., although several authors insisted on its effectiveness. However TrтsсHACK may deny a change in the number of molts caused by the climate, one must consider the facts pointed out by Diммоск and the results obtained by the present author.

From what is mentioned above, the number of molts of insects is changed in two ways, one adds to the normal number of molts, the other diminishes it. In the former, lack of food is one of the primary agents, while, in the latter, climatic influences play an important rôle in lepidopterous larvae. I cannot answer, at this moment, the question whether any decrease in quantity of the metabolic end product gives rise to a deficient number of molts, as the five-molter is produced by accumulating oxides, because we have no full knowledge of the metabolism of the silkworm larva at different temperatures. The problem of the differences by races, inbred and outbred, and by stages of the life history, embryonic and larval, regarding the molting numbers in the silkworm, also must be postponed until more complete data are accumulated.

\section{Summary of Part II}

1. The occurrence of the three-molter out of the four-molting races is influenced by light and temperature during incubation in the following ways. a) It occurs more frequently at $20^{\circ}$, less at $15^{\circ}$, with very few at $25^{\circ}$ and $30^{\circ} \mathrm{C}$. At the temperatures between $15^{\circ}$ and $25^{\circ}$, darkness is more favorable than light for producing three-molters. b) At 12 hours or less exposure to light, the results are equal to those in the dark, while 15 hours or more exposure proves as effective as the continuous light. c) The rays of 
the wave-lengths larger than $5500 \AA$ have no inbibitory action, but those of the smaller wave-lengths have. d) From the beginning of incubation to the blastokinesis of the embryo and during one or two days after the completion of the embryo, high temperature and light are more conducive to the thrce-molter than low temperature and darkness. In the intermediate period from the blastokinesis to the completion of the embryo, however, light and temperature act in a directly opposite way.

2. The occurrence of the three-molter mostly depends upon light and temperature during the larval period. It varies under the following conditions. a) When temperature rises, the number of the three-molters increases, more rapidly in the light than in the dark. b) Below $28^{\circ} \mathrm{C}$, the rays larger than $5500 \AA$, and above $30^{\circ}$, the rays smaller than that favor the production of the threemolter. c) Below $28^{\circ} \mathrm{C}$. less than 12 hours exposure to light is more favorable to the production of the three-molter, while above $30^{\circ}$, the more the daily exposure, the larger the resulting production. d) The effects of light and temperature are greatest in the first and second stadia, less in the third, with none in the fourth stadium. If subjected to high temperature and light from the first to the third stadium, a maximum effect results.

3. The three-molters caused by light and temperature involve more males than females, representing a sex-ratio of about 80 per cent males.

4. In the hybrids between any two different races, the rate of the appearance of the three-molter is generally larger than in pure races. Racial differences were also observed.

5. The molting of insects is due to the accumulation of certain metabolic end products such as oxides.

6. The variability of the number of molts of insects is seen in two ways as shown below: a) The increase of molts is mostly caused by lack of food. b) The decrease of them is mainly dependent upon climatic influences, especially upon light and temperature. 


\section{Bibliography}

\section{For Part I}

1. Bufcrok K. W. 1924. Environmental studies on the European corn borer (Pyrausta nubilalis IIübn.). Jour. Fcon. Ent., Vol. 17.

2. - -. 1927. The European corn borer, Pyrausta mubilalis Hübn. I. A discussion of its dormant period. Ecology, Vol. 8.

3. B.sprk, G. W. 1925. Remarks on the number of generations of the European corn borer in America. Jour. Fcon. Ent., Vol. 18.

4. Bamazkger, J. P. 1917. Hibernation: A periodical phenomenon. Ann. Ent. Soc. Amer., Vol. 10.

5. BR EItrenciak, J. K. 1918. The relation of water to the behavior of the Potato beetle in a desert. Pub. Carn. Inst. Wash., No. 263.

f. CAsti. F, W. E. 1910. The effect of selection upon Mendelian characters manifested in one sex only. Jour. Exp. Zoöl., Vol. 8.

7. Cirgntakx, M. L. 1918. First report on the inheritance of visible and invisiblo characters in silkworms. Proc. Zoöl. Soc. London.

8. Cinwsirl, H. G. 1922. The luropenn corn borer (Pyrausta nubilalis Hübn.) : Life history in Ontario. Jour. Econ. Ent., Vol. 15.

9. Dawsin, W. R. 1931. The problem of voltinism and domancy in the polyphemus moth (Telea polyphemus Cramer). Jour. Exp. Zoöl, Vol. 59.

10. Di, M. N. 1915. First report on the experiments carried out at Pusa to improve the mulberry silk industry. Bull. Pusa, Vol. 18.

11. FARKA, K. 1903. Beitäge zur Energetik der Ontogenese. Ucber den Encr. gieumsatz des Seidenspinners wärend der Entwicklung in Ei und wärend der Metamorphose. Pfl. Arch. Phys., Bd. 98.

12. Hamsix, J. C. 1923. Seasonal adaptation of a northern hemisphere insect to the southern hemisphere. Jour. Econ. Ent., Vol. 16

13. HARAn, H. 1921. On the relation between hibernation and moisture during egg incubation. (in Jap.) Ueda-Gensan-Hokoku, No. 4.

14. Kr. M. M. 1930. On voltinism of the sillworm eggs. in Jap.) Nagano-ken. Shikenjyo-Hokoku, No. 11.

15. Macnis, J. 1926. The development of the ovary in the silkworm (Bombyr mori). Jour. Coll. Agri. Tokyo Imp. Uni., Vol. 7.

16. McCRACKIX, I. 1909. Heredity of the race-characters univoltinism and bivoltinism in the silkworm. Jour. Exp. Zoöl, Vol. 7 .

17. Marcoviscil, S. 1924. The migration of Aphidae and the appearance of the sexual forms as affected by the relative length of daily light exposures. Jour. Agr. Res., Vol. 27.

18. Mirsuntex, S. 1928. On the effect of temperature upon action of enzymes in the silkworm. in Jap.) Nagano-ken-Shikenjo-Hokoku, No. 6.

19. Mi\%x, T. 1925. On voltinism of the silkworm. (in Jap.) Sakura-katiho, No. 17.

20. Puker, H. L, and Timsses, W. R. 1927. A contribution to the study of hibernation in the larva of the European corn borer. (Pyrausta nubilalis Hübn.) Ann. Ent. Soc. Amer., Vol. 20.

21. Picard, F. 1927. L'hibernation des chenilles de Pieris brassicae L. Bull. Biol. de France et de Belgique, T. 57 . 
22. Ronisson, W. 1929. A study of the effect of surgical stock on insects. Jour. Agr. Res., Vol. 37.

23. Ronkxn, F, 1922. Etude sur le sommiel d'live pre-imaginal des Muscides. Bull. Biol. de France et de Belgique, T. 56.

24. Shilfori), V. F. 1927. An experimental investigation of the relations of the codling moth to weather. Bull. Ill. St. Nat. Hist. Surv., Vol. 16.

25. - 1929. Laboratory and field ecology.

26. Simk lik, C. S. 1927. A study of the catalase content of codling math larvae. Bull. Ill. St. Nat. Hist. Surv., Vol. 16.

27. TANaka, Y. 1920. Lectures on the physiology of the silkworm. (in Jap.;

28. - - 1924. Maternal inheritance in Bombys mori. Genetics, Vol. 9.

29. Thwe, W. T. 1936. An investigation of evolution of chrysomelid beetles of the Genus Lcptinotarsa. Pub. Carn. Inst. Wash., No. 48.

30. T)xisis, M. T. 1926. The breaking-up of hibernation in the codling moth. Ann. Ent. Suc. Amer., Vol. 19.

31. Tryma, K. 1906. Mendel's law of heredity as applied to the silkworm characters. Biol. Zentralbl., Bd. 26.

32. - - 1913. Maternal inheritance and Mendelism. Jour. Gen., Vol. 2.

33. UEA, 11. 1923. On " maternal inheritance." Genetics, Yol. 8.

34. LMin, Y. 1926. Experiments on ovarian transplantation and blood transfusion in silkworms, with special reference to the alternation of voltinism. Bull. Seri. Exp. St. Chosen, Vol. 1.

35. - 1928. On an agent which alters the nature of yoltinism of the silkworm, (in Jap.) Dainippon-Sanshikaiho, Vol. 37 .

36. WAaxaBa, K. 1921. On the relation between the color of the silkworm cyrs and environmental stimuli (II). (in Jap.) Sangyoshikenjo-Hokoku, Vol. 4.

37. .... 1924. Studics on voltinism of the silkworm. (in Jap.) SangyoshikenjoHokolu, Vol. 6.

38. - 1928. Further studies on voltinism of the silkworm. (in Jap.) Sangyoshikenjo-Hokoku, Vol. 7 .

\section{For Part II}

39 Akssir, H. 1911, An opinion on the five-molter (in Jap.) Dainippon-Sanshikaiho, No. 236 .

40. Bakns, J. If. and Grovi, A. J., 1916. The insects attacking stored wheat in the Punjab, and methods of combating them, including a chapter on the chemis. try of respiration. Mem. of Depart. Agr. India, Vol. 4.

41. Butk, H. 1923. Die Entwicklung des Dytiscus marginalis L. von Ei bis zur Imago. 2 Teil. Die Metamorphose. Zeit. f. wiss. Zool., Bd. 155.

42. Cмmsтиск, J. H. 1924. An introduction to entomology.

43. DrM ck, A.K. 1888. Variable number of molts of insects. Psyche, Vol. 5.

44. Dr:k, H. G. 1890. The number of molts of lepidopterous larvae. P'syche, Vol. 5.

45. Elswix, H. 1924. Untersuchungen über den Mechanismus der Häutung bei den Insekten. Arch. f. Mikrosk. Anat. u. Entw.-Mech., Bd. 102.

46. - 1924. Lntersuchungen über Wachstum und Häutung der Insekten. Zeit. f. Morph. u. Oekol., Bd. 2. 
47. Fischer, E. 1920. Die Häutungszahl der Argynnis-Raupen und die Körpermaße der verschiedenen Stadien als cin Ausdruck der Fibonacci-Reihe. Entom. Zeit., 34.

48. HF, , S. 1923. Larvenarten von der Gatlung Tenchio und ihre Kultur. Entom. Mitteil., Bd. 12.

49. Hiratsika, F. 1920. Researches on the nutrition of the silk worm. Bull. Imp. Seri. Exp. St. Jap., Vol. 1.

50. Howard, L. O. and Martatt, C. L. 1893. Tne principal household insects of the United States. U. S. Depart. Agr. Div. Ent. Bull., No. 4.

51. IKzDA, E. 1911. Increase and decrease of a molt of the silkworm. (in Jap.) Sangyoshimpo, No. 225.

52. Ismwata, S. 1900. Cause of the occurrence of the three-molter. (in Jap.) KyotoSanjihokoku, No. 16.

53. КАт, T. 1911. On the five-molter. (in Jap.) Dainippon-Sanshikaiho, No. 236.

54. Kawnsr, S. 1914. Studies on the respiration of the silkworm. (in Jap.) Nogakukaiho, No. 185.

55. Kawast, S. and Karasawa, K. 1914. On the occurrence of the five-molter. (in Jap.) Leda-Dosokaiho, No. 1.

56. Kц.^тт, B. 1920. Beiträge zur Sexualphysiologie des Schwammspinners. Biol. Zentralbl., Bd. 50.

57. Luzскх, J. 1865. On the development of Chlö̈on (Ephemera) dimidiatum. Trans. Linn. Soc. London, Vol. 24.

58. Matsusitik, S. 1929. On the influence of temperature upon the silkworm. (in Jap.) Nagano-ken-Shikenjo-Hokoku, No. 9.

59. Müı, fR, G. H. 1925. Kalk in der Haut der Insekten und die Larve von Sargus cuprarius L. Zeit. f. Morph. u. Oekol., Bd. 3.

60. Mirmir, H. E. 1922. Notes on the biology of some of our North American species of may-flies. II. Notes on the biology of may-flies of the genus Baëtis. Bull. Lioyd Library, 22.

61. Nagamor., S. 1927. Influence of external agents on the molting character of the silkworm, Bombyx mori L. Proc. Imp. Acad., Vol. 3.

62. - 1931. Influence of external agents on the molting character of the silkworm, especially during the incubation period. (in Jap.) Oyo-dobutsugakukaiho, Vol. 3.

63. Nw^, S. 1911. On the molting of insects, with special reference to the five molter of the silkworm. (in Jap.) Dainippon-Sanshikaiho, No. 236.

64. Orisis, H. and Jrik, K. 1929. On the influence of temperature upon the silkworm larvae and pupae. (in Jap.) Kumamoto-ken-Shikenjo-Hokoku, Vol. 2.

E5. PAckard, A. S. 1909. $\Lambda$ text-book of entomology.

€6. Pıлтхкок, W. 1904. Ueber die Häutung und über einige Elemente der Haut bei den Insekten. Zeit. f. wiss. Zool., Bd. 76.

67. Pirzroks, $\mathrm{H}$. and Mrgusar, F. 1912. Wachstumsmessungen an Sphodromantis bioculata Burm. I. Iänge und Masse. Arch. f. Entw.-Mech., Bd. 34.

68. SAKA, B. 1926. On the influence of the leaves attacked by Yakedake ash. (in Jap.) Nagano-ken-Shikenjo-Hokoku, No. 1.

69. Sснст.7., P. 1912. Ueber Versondrüsen bei Lepidopteren. Zool. Anz., Bd. 39.

70. Srvirin, H. H. and Severin, C. II. 1913. The effect of temperature on the molting of walking-stick, Diapheromera femorata Say (Orthop). Ent. News, Vol. 24. 
71. Shafrk, G. D. 1923. The growth of dragonfly nymphs at the molt and between molts. Stanford Univ. Pub. Series Biol. Sci., Vol. 3.

72. TaNaks, Y. 1917. Heredity and brecding of the silkworm. (in Jap.)

73. Tiтsciack, E. 1924. Lntersuchungen über das Wachstum, den Nahrungsverbrauch und die Eierzeugung. I. Carausius morosus, Zeit. f. wiss. Zool., Bd. 123.

74. - - 1926. Untersuchungen über das Wachstum, den Nahrungsverbrauch und die Eierzeugung. II. Tineolz biselliela Hum. Gleichzeitig ein Beitrag zur Klärung der Insektenhautung. Zcit. f. wiss. Zool., Bd. 128.

75. TUWER, W. L. 1906. Observation on the changes in the hypodermis and cuticula of Coleoptera during ecdysis. Biol. Bull., Vol. 10.

76. Versov, E. 1911. Beitrag zur nähren Kenntnis der Häutung und der Häutungsdrüsen bei Bombyx mori. Zeit. f. wiss. Zool., Bd. 97.

77. Vozkг, H. 1924. Ueber die Biologie und Bekämpfung von Trogoderma granarium Everts. Verh. d. Deut. Ges. f. angew. Ent., 4.

78. WAcltTkk, S. 1930. The moulting of the silkworm and a histological study of the moulting glands. Ann. Ent. Soc. Amer., Vol. 23.

79. Yokora, C. 1912. Production of the five-molter of the silkworm. (in Jap.) Dainippon-Sanshikaiho, No. 250. 